\title{
Redox Character and Small Molecule Reactivity of a Masked Titanium(II) Synthon
}

\author{
J. Rolando Aguilar-Calderón, Jesse Murillo,,${ }^{\ddagger}$ Alejandra Gomez-Torres, ${ }^{,}$Carlos Saucedo,,${ }^{\ddagger}$ Aldo Jordan, \\ Alejandro J. Metta-Magaña, ${ }^{,}$Maren Pink, ${ }^{\dagger}$ and Skye Fortier, ${ }^{*}+\infty$
}

${ }^{*}$ Department of Chemistry and Biochemistry, University of Texas at El Paso, El Paso, Texas 79968, United States

${ }^{\dagger}$ Indiana University Molecular Structure Center, Indiana University, Bloomington, Indiana 47405, United States

\section{Supporting Information}

\begin{abstract}
The two-electron reduction of the $\mathrm{Ti}(\mathrm{IV})$ guanidinate ( ${ }^{\mathrm{Ket}}$ guan)$\left(\mathrm{Im}^{\text {Dipp }} \mathrm{N}\right) \mathrm{Ti}(\mathrm{OTf})_{2}\left(2^{\text {OTf }}\right)\left({ }^{\text {Ket }}\right.$ guan $=\left[\left({ }^{t} \mathrm{Bu}_{2} \mathrm{C}=\mathrm{N}\right) \mathrm{C}(\mathrm{NDipp})_{2}\right]^{-} ; \mathrm{Im}^{\mathrm{Dipp}} \mathrm{N}^{-}=$ 1,3-bis(Dipp)imidazolin-2-iminato; Dipp = 2,6-diisopropylphenyl) with an excess of $\mathrm{KC}_{8}$ generates the masked complex ( ${ }^{\text {Ket }}$ guan $)\left(\eta^{6}-\mathrm{Im}^{\text {Dipp }} \mathrm{N}\right) \mathrm{Ti}$ (1). Conversely, reduction of the chloride analogue ( ${ }^{\text {Ket }}$ guan $)\left(\operatorname{Im}^{\text {Dipp }} \mathrm{N}\right) \mathrm{TiCl}_{2}\left(2^{\mathrm{Cl}}\right)$ with an excess of $\mathrm{Na} / \mathrm{Hg}$ amalgam produces the $\mathrm{Ti}(\mathrm{III})$ compound (Ket guan)$\left(\mathrm{Im}^{\text {Dipp }} \mathrm{N}\right) \mathrm{TiCl}$ (3), while treatment of $2^{\mathrm{Cl}}$ with 3.0 equiv of $\mathrm{KC}_{8}$ affords a complicated mixture from which $\left(\mathrm{Im}^{\mathrm{Dipp}} \mathrm{N}\right)(\mathrm{DippN}=)\left[\eta^{2}-\left({ }^{t} \mathrm{Bu}_{2} \mathrm{C}\right)\right.$ $\mathrm{NC}(\mathrm{NDipp})]$ (THF)Ti (4) is isolated as the product of reductive ligand cleavage. These results clearly indicate that the success of early metal reduction chemistry is highly sensitive to the halide coligands and reaction conditions. Complex 1, despite possessing a $\mathrm{Ti}(\mathrm{IV})$ canonical form, behaves as a $\mathrm{Ti}(\mathrm{II})$

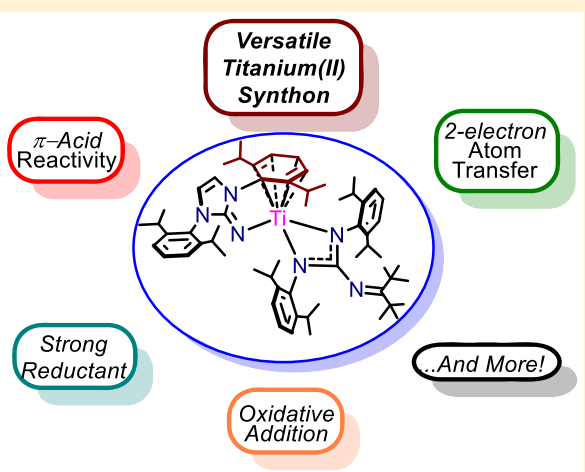
synthon and appreciable reducing agent. For instance, 1 effects the one-electron reduction of benzophenone and pyridine to give the $\mathrm{Ti}(\mathrm{III})$ products ( ${ }^{\text {Ket }}$ guan $)\left(\mathrm{Im}^{\mathrm{Dipp}} \mathrm{N}\right) \mathrm{Ti}\left(\eta^{1}-\mathrm{OC} \cdot \mathrm{Ph} \mathrm{h}_{2}\right)(6)$ and $\left[\left({ }^{\text {Ket }} \text { guan }\right)\left(\mathrm{Im}^{\text {Dipp }} \mathrm{N}\right) \mathrm{Ti}\right]_{2}\left[\mu^{2}-\left(\mathrm{NC}_{5} \mathrm{H}_{5}-\mathrm{H}_{5} \mathrm{C}_{5} \mathrm{~N}\right)\right](7)$, providing an approximate chemical redox potential range for 1 between ca. -2.3 to $-3.1 \mathrm{~V}\left(\mathrm{vs}\left[\mathrm{Cp}_{2} \mathrm{Fe}\right]^{0 /+}\right)$. Additionally, treatment of 1 with $\pi$-acids such as $\mathrm{C} \equiv \mathrm{NCy}\left(\mathrm{Cy}=\right.$ cyclohexyl) or $\mathrm{N} \equiv \mathrm{C}^{t} \mathrm{Bu}$ leads to the formation of the $\mathrm{Ti}(\mathrm{III})$ and $\mathrm{Ti}(\mathrm{IV})$ products $\left({ }^{\mathrm{Ket}}\right.$ guan $)\left(\operatorname{Im}^{\mathrm{Dipp}} \mathrm{N}\right) \mathrm{Ti}(\mathrm{CN})(\mathrm{CNCy})(\mathbf{9})$ and $\left(\mathrm{Im}{ }^{\mathrm{Dipp}} \mathrm{N}\right)[(\mathrm{DippN})-$ $\left.\left(2-{ }^{i} \mathrm{PrC}_{6} \mathrm{H}_{3}-6-\left(\eta^{1}-\mathrm{CH}_{3} \mathrm{CHCH}_{2}\right) \mathrm{N}\right) \mathrm{C}\left(\mathrm{NC}^{t} \mathrm{Bu}_{2}\right)\right] \mathrm{Ti}\left[\mathrm{NC}(\mathrm{H})^{t} \mathrm{Bu}\right](10)$, respectively, via reduction of the $\pi$-acid substrate. The two-electron reduction proclivity of $\mathbf{1}$ is demonstrated by its reactivity with chalcogen sources (e.g., $\mathrm{N}_{2} \mathrm{O}$ ) and organoazides to give the $\mathrm{Ti}(\mathrm{IV})$ products $\left({ }^{\mathrm{Ket}}\right.$ guan $)\left(\operatorname{Im}{ }^{\mathrm{Dipp}} \mathrm{N}\right) \mathrm{Ti}(=\mathrm{E})\left(\mathrm{E}=\mathrm{O}(\mathbf{1 3}), \mathrm{S}(\mathbf{1 4}), \mathrm{Se}(\mathbf{1 5}), \mathrm{S}_{2}(\mathbf{1 6}), \mathrm{NSiMe}_{3}(\mathbf{1 7}), \mathrm{NAd}(\mathbf{1 8})\right) . \mathrm{In}$ addition to illustrating the versatile $\mathrm{Ti}(\mathrm{II})$ synthon character of $\mathbf{1}$, the synthesis of these compounds shows that the $3 \mathrm{~N}$ coordinated $\left[\left({ }^{\text {Ket }} \text { guan }\right)\left(\mathrm{Im}^{\text {Dipp }} \mathrm{N}\right) \mathrm{Ti}\right]^{n+}$ manifold can readily accommodate metal-ligand multiple bonds, including relatively rare examples of terminally bound $\mathrm{Ti}=\mathrm{S}$ and $\mathrm{Ti}=\mathrm{Se}$ bonds. Taken altogether, the redox chemistry of $\mathbf{1}$, as a $\mathrm{Ti}$ (II) synthon, clearly shows the chemical diversity of low-valent early metals (LVEMs) and their ability to reductively activate a wide range of substrates.
\end{abstract}

\section{INTRODUCTION}

The early transition metals, i.e., groups 3-5, are typically distinguished by their high electropositive character and thermodynamic preference for $d^{0}$ valencies. Accordingly, these metals are routinely utilized as potent Lewis acid activators or catalysts in preparative organic chemistry such as in Friedel-Crafts and Diels-Alder reactions. ${ }^{1,2}$ On the industrial scale, the early metals are widely known for their utility in Ziegler-Natta catalysis for the polymerization of olefins such as ethylene. ${ }^{3}$ However, the chemistry of low-valent early metals (LVEMs), as defined by electron counts $\geq d^{2}$, is accessible and plays a critical role in a number of practical chemical transformations. ${ }^{4,5}$ LVEMs have been utilized in natural product syntheses, ${ }^{5-11}$ can induce the coupling and cyclization of alkenes and alkynes, ${ }^{7,12-19}$ and are especially adept at McMurry and Pinacol reductive aldehyde and ketone coupling reactions. ${ }^{8,20-22}$
To a smaller extent, the reductive prowess of LVEMs has been utilized to perform challenging chemical transformations such as the reductive cleavage of $\mathrm{CO},{ }^{23-25} \mathrm{C}-\mathrm{H}$ bond activation via oxidative addition, ${ }^{26-33}$ and the reduction and functionalization of $\mathrm{N}_{2} \cdot{ }^{31,33-37}$ In fact, low-valent titanium complexes have been shown to be sufficiently reducing to effect the catalytic activation of $\mathrm{N}_{2}$ for nitrogen incorporation into organic compounds. ${ }^{11}$ For instance, treatment of substoichiometric amounts of $\mathrm{TiCl}_{4}$ with an excess of $\mathrm{Li}^{0}$ and $\mathrm{Me}_{3} \mathrm{SiCl}$ under $\mathrm{N}_{2}$ can nitrogenate ketoalkynes to indoles in modest yields. ${ }^{11}$ Not surprisingly, LVEMs are typically highly reactive and strong reductants that are prone to disproportionation, complicating their synthesis, handling, storage, and utility. For example, the $\mathrm{Ti}(\mathrm{II})$ compounds $\mathrm{TiCl}_{2}(\text { py })_{4}\left(\right.$ py $\left.=\mathrm{C}_{5} \mathrm{H}_{5} \mathrm{~N}\right)$ and $\mathrm{TiCl}_{2}(\text { tmeda })_{2}($ tmeda $=$

Received: September 20, 2019

Published: November 20, 2019 
$\left.\left[\left(\mathrm{CH}_{3}\right)_{2} \mathrm{NCH}_{2}\right]_{2}\right)$ are effective two-electron reductants that do not persist in solution, giving $\mathrm{Ti}(\mathrm{III})$ products and intractable solids upon standing. ${ }^{38-40}$

To address this issue, the stabilization of LVEM complexes is usually achieved by use of $\pi$-acids, specifically $\mathrm{CO},{ }^{41}$ phosphines, ${ }^{42}$ and unsaturated hydrocarbons ${ }^{43}$ to alleviate metal-centered charge density. Indeed, LVEMs are often sufficiently electron rich to engage the $\pi^{*}$-orbitals of aromatic molecules which can give rise to significant charge transfer and formal reduction of the arene moiety. ${ }^{44-48}$ As an extreme example, Diaconescu and co-workers have shown that reduction of $\left(\mathrm{NN}^{\mathrm{fc}}\right) \mathrm{YI}(\mathrm{THF})_{2}\left(\mathrm{NN}^{\mathrm{fc}}=\mathrm{fc}\left(\mathrm{NSi}^{t} \mathrm{BuMe}_{2}\right)_{2}, \mathrm{fc}=\right.$ 1,1 -ferrocenediyl) with 4 equiv of potassium graphite $\left(\mathrm{KC}_{8}\right)$ in the presence of biphenyl generates the dinuclear inverted sandwich complex $\left[\left(\mathrm{NN}^{\mathrm{fc}}\right) \mathrm{Y}\right]_{2}[\mathrm{~K}$ (toluene $\left.)\right]_{2}(\mu$-biphenyl $)$ featuring formally trivalent yttrium with a bridging, tetraanionic biphenylide ligand. $^{49}$

Indeed, the propensity of LVEMs to reduce aromatic systems can lead to intramolecular reduction of peripheral arene substituents on otherwise redox innocent ligands. For instance, Power et al. showed that the one-electron reduction of the $\mathrm{Ti}(\mathrm{III})$ complex $\mathrm{TiCl}\left[\mathrm{N}(\mathrm{H}) \mathrm{Ar}^{\mathrm{iPr} 6}\right]_{2}\left(\mathrm{Ar}^{\mathrm{iPr} 6}=\mathrm{C}_{6} \mathrm{H}_{3}-2,6-\right.$ $\left.\left(\mathrm{C}_{6} \mathrm{H}_{2}-2,4,6-{ }^{i} \mathrm{Pr}_{3}\right)_{2}\right)$ leads to the formation of $\mathrm{Ti}\left[\left(\eta^{6}-\right.\right.$ $\left.\left.\mathrm{Ar}^{\mathrm{iPr6}} \mathrm{NH}\right)\left(\mathrm{Ar}^{\mathrm{iPr} 6} \mathrm{NH}\right)\right]$ featuring a formally $\mathrm{Ti}(\mathrm{IV})$ center with a masking cyclohexadiene dianion ring from reduction of one of the terphenyl amide ligands. ${ }^{44}$ Similarly, Stephan and co-workers have demonstrated that magnesium reduction of $\mathrm{CpTi}\left[\mathrm{NP}^{t} \mathrm{Bu}_{2}\left(2-\mathrm{C}_{6} \mathrm{H}_{4} \mathrm{Ph}\right)\right] \mathrm{Cl}_{2}$ gives rise to the $\mathrm{Ti}(\mathrm{IV})$ complex $\mathrm{CpTi}\left[\mathrm{NP}^{t} \mathrm{Bu}_{2}\left(2-\mathrm{C}_{6} \mathrm{H}_{4} \mathrm{Ph}\right)\right]$ featuring a capping interaction by a flanking, dianionic, aryl substituent. ${ }^{50}$ Further reactivity was not described in either case; however, these two reduced complexes would be anticipated to be competent reductants owing to the driving force energy provided by ring rearomatization. Thus, we assert that accessing these masking motifs via early metal reduction and strategic ligand design is a viable approach for obtaining isolable but highly reactive divalent synthons.

To this effect, we recently reported the synthesis of the intramolecularly arene-masked titanium complex (Ket $\left.{ }^{\text {guan }}\right)\left(\eta^{6}\right.$ $\left.\operatorname{Im}^{\text {Dipp }} \mathrm{N}\right) \mathrm{Ti}(\mathbf{1})\left({ }^{\text {Ket }}\right.$ guan $=\left[\left({ }^{t} \mathrm{Bu}_{2} \mathrm{C}=\mathrm{N}\right) \mathrm{C}(\mathrm{NDipp})_{2}\right]^{-}$; $\mathrm{Im}^{\text {Dipp }} \mathrm{N}^{-}=1,3$-bis(Dipp)imidazolin-2-iminato, Dipp $=2,6-$ diisopropylphenyl) formed upon the two-electron reduction of $\left({ }^{\text {Ket }}\right.$ guan $)\left(\mathrm{Im}^{\text {Dipp }} \mathrm{N}\right) \mathrm{Ti}^{\mathrm{IV}}(\mathrm{OTf})_{2} \quad\left(2^{\mathrm{OTf}}\right)$ with 2.5 equiv of potassium graphite. ${ }^{51}$ Upon the basis of its structural parameters, 1 may be considered as possessing a $\mathrm{Ti}(\mathrm{IV})$ center capped by a pendant 1,4-cyclohexadiene dianion ring. Complex $\mathbf{1}$ is stable as a solid under an $\mathrm{N}_{2}$ atmosphere, but in nonpolar solutions, gradually undergoes two-electron oxidation via $\mathrm{H}_{2}$ loss to give the $\mathrm{Ti}(\mathrm{IV})$ metallacycle $\left(\operatorname{Im}^{\mathrm{Dipp}} \mathrm{N}\right)$ $\left[(\mathrm{DippN})\left(2-{ }^{i} \mathrm{PrC}_{6} \mathrm{H}_{3}-6-\left(\eta^{2}-\mathrm{CH}_{3} \mathrm{CCH}_{2}\right) \mathrm{N}\right) \mathrm{C}\left(\mathrm{NC}^{t} \mathrm{Bu}_{2}\right)\right] \mathrm{Ti}$ (5). ${ }^{51}$ This transformation seemingly signifies a highly reducing system that can mediate $\mathrm{C}-\mathrm{H}$ bond activation. Curiously, though, treatment of 1 with $\mathrm{CO}$ affords the $\mathrm{Ti}(\mathrm{II})$ complex ( ${ }^{\text {Ket }}$ guan $)\left(\mathrm{Im}^{\mathrm{Dipp}} \mathrm{N}\right) \mathrm{Ti}(\mathrm{CO})_{2}(8)$ in low yield wherein infrared spectroscopy indicates little to modest activation of the $\mathrm{CO}$ units. ${ }^{51}$

In an effort to better understand the redox properties and reductive abilities of $\mathbf{1}$ and further expand the LVEM chemistry of titanium, we have performed a series of reactions with a wide range of substrates including small molecules. We here describe the $\mathrm{Ti}(\mathrm{III})$ and $\mathrm{Ti}(\mathrm{IV})$ products of these reactions, chemistry that unequivocally validates the characterization of 1 as a versatile $\mathrm{Ti}$ (II) synthon. In our investigation, we have found 1 to be an attractive platform for entry into $\mathrm{Ti}(\mathrm{II})$ chemistry as the $3 \mathrm{~N}$-coordinated ligand manifold with its isopropyl and tert-butyl substituents affords highly crystalline products with tell-tale NMR spectroscopic features. Additionally, the steric profile of the ligand framework generates an axially positioned pocket for directing reactivity and access to the metal.

\section{RESULTS AND DISCUSSION}

Redox Characteristics. While $\mathbf{1}$ is formed by treatment of $2^{\mathrm{OTf}}$ with 2.5 equiv of $\mathrm{KC}_{8}{ }^{51}$ initially in our preliminary studies, we sought to access low valent titanium species through the reduction of the $\mathrm{Ti}(\mathrm{IV})$ dichloride precursor $\left({ }^{\mathrm{Ket}}\right.$ guan $)\left(\mathrm{Im}^{\mathrm{Dipp}} \mathrm{N}\right) \mathrm{TiCl}_{2}\left(2^{\mathrm{Cl}}\right)$. Addition of sodium mercury amalgam (4 equiv) to an orange toluene slurry of $2^{\mathrm{Cl}}$ with stirring at room temperature for 3 days leads to the formation of a green solution from which the $\mathrm{Ti}$ (III) complex ( ${ }^{\text {Ket }}$ guan $)\left(\mathrm{Im}^{\text {Dipp }} \mathrm{N}\right) \mathrm{TiCl}(3)$ is isolated as a pale green solid in $89 \%$ yield (eq 1). Lower yields are obtained with magnesium turnings (10 equiv) and THF as reaction solvents $(60 \%)$.

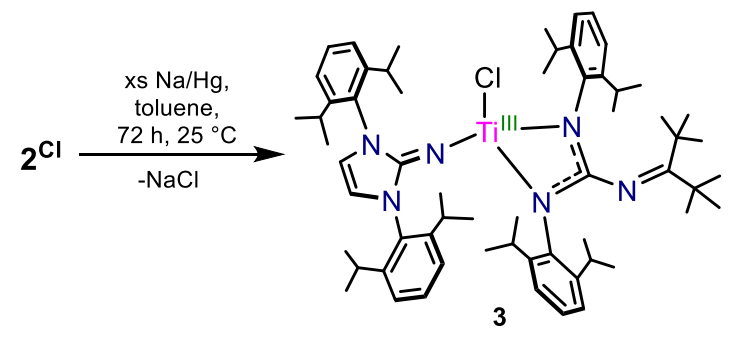

The ${ }^{1} \mathrm{H}$ NMR spectrum of 3 in $\mathrm{C}_{6} \mathrm{D}_{6}$ features broad, illdefined resonances between 0.0 and $8.70 \mathrm{ppm}$ (Figure S1) consistent with a paramagnetic species. Accordingly, the room temperature EPR spectrum of $\mathbf{3}$ in toluene features an isotropic signal with $g=1.956$ attributable to a $\mathrm{Ti}(\mathrm{III})$ center (Figure S56). ${ }^{52}$

Single crystals of $3 \cdot \mathrm{Et}_{2} \mathrm{O}$ were grown from concentrated $\mathrm{Et}_{2} \mathrm{O}$ solutions stored at $-25{ }^{\circ} \mathrm{C}$ for 2 days and crystallize in the monoclinic space group $P 2_{1} / c$. Inspection of the solid-state molecular structure through X-ray crystallographic analysis shows a four-coordinate titanium center with distorted tetrahedral geometry (e.g., $\mathrm{N} 1-\mathrm{Til}-\mathrm{Cl} 1=118.03(6)^{\circ}$; $\mathrm{N} 1-$ Ti1-N2 $=118.77(7)^{\circ}$ ) as displayed in Figure 1 . The chloride atom resides in the apical position within a pocket formed by the peripheral Dipp groups. The Til-Cl1 = 2.295(1) $\AA$ bond length is identical to that found in the related $3 \mathrm{~N}$-coordinated $\mathrm{Ti}(\mathrm{III}) \quad \beta$-diketiminate complex $\left\{\left[(\mathrm{Dipp}) \mathrm{NC}\left(\mathrm{CH}_{3}\right)\right]_{2} \mathrm{CH}\right\}$ $\mathrm{TiCl}\left[\mathrm{N}\left(\mathrm{SiMe}_{3}\right)_{2}\right](\mathrm{Til}-\mathrm{Cl} 1=2.2950(5) \AA) .{ }^{53}$ In the absence of a solid-state molecular structure for $2^{\mathrm{Cl}}$, further structural comparisons can be made to its surrogate $\left[\left(\mathrm{Et}_{2} \mathrm{~N}\right) \mathrm{C}\right.$ (NDipp) $\left.)_{2}\right]\left(\mathrm{Im}^{\prime} \mathrm{N}\right) \mathrm{TiCl}_{2}\left(\mathrm{Im}^{\prime} \mathrm{N}=1,3\right.$-bis(2,6-dimethylphenyl)imidazolidin-2-iminato). ${ }^{54}$ The guanidinate $\mathrm{Ti}-\mathrm{N}$ distances of $3 \cdot \mathrm{Et}_{2} \mathrm{O}(\mathrm{Ti} 1-\mathrm{N} 3=2.098(2) \AA ; \mathrm{Ti} 1-\mathrm{N} 2=2.085(2) \AA)$ are within the range reported for $\left[\left(\mathrm{Et}_{2} \mathrm{~N}\right) \mathrm{C}(\mathrm{NDipp})_{2}\right]\left(\mathrm{Im}^{\prime} \mathrm{N}\right)$ $\mathrm{TiCl}_{2}(\mathrm{Ti}-\mathrm{N}=2.097(2) \AA ; 2.150(4) \AA)$. However, disparities are observed in the $\mathrm{Ti}-\mathrm{N}_{\mathrm{Im}}$ bonding parameters as the Til$\mathrm{N} 1=1.852(2) \AA$ bond distance and Ti1-N1-C1 $=158.2(2)^{\circ}$ bond angle of $3 \cdot \mathrm{Et}_{2} \mathrm{O}$ is elongated and more acute than the corresponding $\mathrm{Ti}-\mathrm{N}_{\mathrm{Im}}=1.765(3) \AA$ and $\mathrm{Ti}-\mathrm{N}_{\mathrm{Im}}-\mathrm{C}_{\mathrm{Im}}=$ $170.5(3)^{\circ}$ metrics in $\left[\left(\mathrm{Et}_{2} \mathrm{~N}\right) \mathrm{C}(\mathrm{NDipp})_{2}\right]\left(\mathrm{Im}^{\prime} \mathrm{N}\right) \mathrm{TiCl}_{2}$. While the longer $\mathrm{Ti}-\mathrm{N}_{\mathrm{Im}}$ distance of $3 \cdot \mathrm{Et}_{2} \mathrm{O}$ could be attributed to 


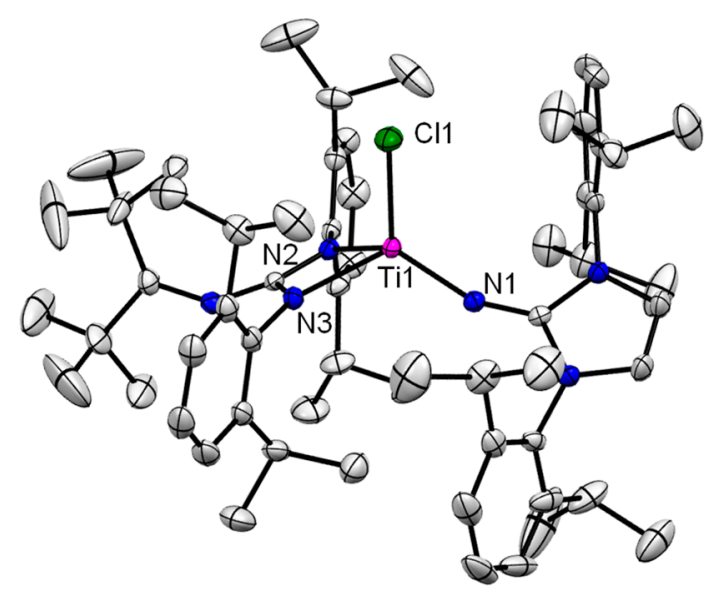

Figure 1. Solid-state molecular structure of $3 \cdot \mathrm{Et}_{2} \mathrm{O}$ with $50 \%$ probability ellipsoids. Hydrogen atoms and cocrystallized $\mathrm{Et}_{2} \mathrm{O}$ omitted for clarity.

the larger ionic radius of $\mathrm{Ti}(\mathrm{III})$ (e.g., $\mathrm{Ti}(\mathrm{III})=0.67 \AA$ vs $\mathrm{Ti}(\mathrm{IV})=0.605 \AA$ for C.N. $=6),{ }^{55}$ we ascribe the differences as a consequence of the greater steric profile of the $\operatorname{Im}^{\text {Dipp }} \mathrm{N}^{-}$ ligand of $3 \cdot \mathrm{Et}_{2} \mathrm{O}$ compared to that of the $\mathrm{Im}^{\prime} \mathrm{N}$ - group in $\left[\left(\mathrm{Et}_{2} \mathrm{~N}\right) \mathrm{C}(\mathrm{NDipp})_{2}\right]\left(\mathrm{Im}^{\prime} \mathrm{N}\right) \mathrm{TiCl}_{2}$.

Interestingly, the inability to access low-valent titanium through the treatment of $2^{\mathrm{Cl}}$ or 3 with excess reducing equivalents of $\mathrm{Na} / \mathrm{Hg}$ amalgam stands in stark contrast to the reduction chemistry of the $\mathrm{Ti}(\mathrm{IV})$ bisguanidinate $\left[\mathrm{Me}_{2} \mathrm{NC}\right.$ $\left.(\mathrm{N} P r)_{2}\right]_{2} \mathrm{TiCl}_{2}$ or $\mathrm{Ti}(\mathrm{IV})$ bisamidinate $\left[\mathrm{PhC}\left(\mathrm{NSiMe}_{3}\right)_{2}\right]_{2} \mathrm{TiCl}_{2}$ complexes, which are readily reduced by two electrons using excess magnesium powder or $\mathrm{Na} / \mathrm{Hg}$ amalgam, respectively, to give the dinitrogen-bridged dinuclear complexes $\left[\mathrm{L}_{2} \mathrm{Ti}\right]_{2}\left(\mathrm{~N}_{2}\right)_{2} .{ }^{56,57}$

The disparity in reduction character seemingly indicates the $3 N$-ligand manifold of our $\left[\left({ }^{\text {Ket }} \text { guan }\right)\left(\operatorname{Im}^{\text {Dipp }} \mathrm{N}\right) \mathrm{Ti}\right]^{n+}$ system has superior donor abilities over the dual amidoimines of $\left[\mathrm{Me}_{2} \mathrm{NC}\left(\mathrm{N}^{i} \mathrm{Pr}\right)_{2}\right]_{2} \mathrm{TiCl}_{2}$ and $\left[\mathrm{PhC}\left(\mathrm{NSiMe}_{3}\right)_{2}\right]_{2} \mathrm{TiCl}_{2}$, which is likely due to the excellent $\sigma$ - and $\pi$-donor abilities of the $\operatorname{Im}^{\text {Dipp }} \mathrm{N}^{-}$ligand. ${ }^{58,59}$ To shed further light on this, the solution redox properties of $2^{\mathrm{Cl}}$ were investigated through cyclic voltammetry using THF as solvent with $\left[\mathrm{NBu}_{4}\right]\left[\mathrm{PF}_{6}\right]$ as the supporting electrolyte. The cyclic voltammogram $(\mathrm{CV})$ of $2^{\mathrm{Cl}}$ (Figure S62) reveals an irreversible $\mathrm{Ti}(\mathrm{IV}) /(\mathrm{III})$ redox wave at $-2.3 \mathrm{~V}\left(\mathrm{vs}\left[\mathrm{Cp}_{2} \mathrm{Fe}\right]^{0 /+}\right)$, which is at the cusp of the $\mathrm{Na} / \mathrm{Hg}$ amalgam redox potential $\left(-2.38 \mathrm{~V}\right.$ vs $\left[\mathrm{Cp}_{2} \mathrm{Fe}\right]^{0 /+}$ in nonaqueous solvent). ${ }^{60}$ Additional reduction features in the $\mathrm{CV}$ of $2^{\mathrm{Cl}}$ were not observed within the range of the solvent window supporting the notion that the ketimine-guanidinate/imidazolin-2-iminato ligand combination provides an especially electronic rich environment at the titanium metal center. Efforts to obtain comparative $\mathrm{CV}$ data for $2^{\text {OTf }}$ were unsuccessful as the compound rapidly decomposes under the conditions of the experiment.

In an attempt to push the reduction chemistry further, $2^{\mathrm{Cl}}$ was treated with an excess of $\mathrm{KC}_{8}$. Treatment of a stirring THF slurry of $2^{\mathrm{Cl}}$ with 3.0 equiv of $\mathrm{KC}_{8}$ at room temperature forms a dark-brown solution accompanied by formation of graphite overnight (eq 2). Filtration of the solution and removal of the volatiles under vacuum produces a brown solid which is highly soluble in aromatic and ethereal solvents. The ${ }^{1} \mathrm{H}$ NMR spectrum of the crude product in $\mathrm{C}_{6} \mathrm{D}_{6}$ reveals a complicated mixture of compounds with the major species exhibiting sharp

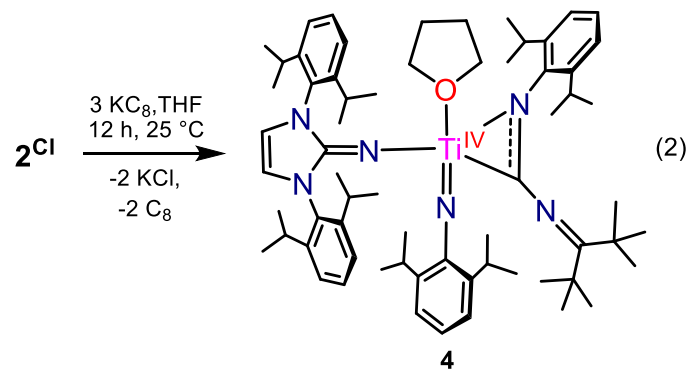

and broad resonances consistent with a diamagnetic product with low molecular symmetry and some fluxional solution-state behavior on the NMR time scale. (Figure S2).

In one instance, single crystals of the major reduction product were isolated as pure material from a THF/hexanes solution stored for 2 days at $-25{ }^{\circ} \mathrm{C}$. The solid-state molecular structure obtained from the $\mathrm{X}$-ray analysis reveals the formation of a five-coordinate $\mathrm{Ti}(\mathrm{IV})$-imido complex $\left(\mathrm{Im}^{\text {Dipp }} \mathrm{N}\right)(\mathrm{DippN}=)\left[\eta^{2}-\left({ }^{t} \mathrm{Bu}_{2} \mathrm{C}\right) N C(\mathrm{NDipp})\right](\mathrm{THF}) \mathrm{Ti}(4)$ as shown in Figure 2. Complex 4 forms from the reductive

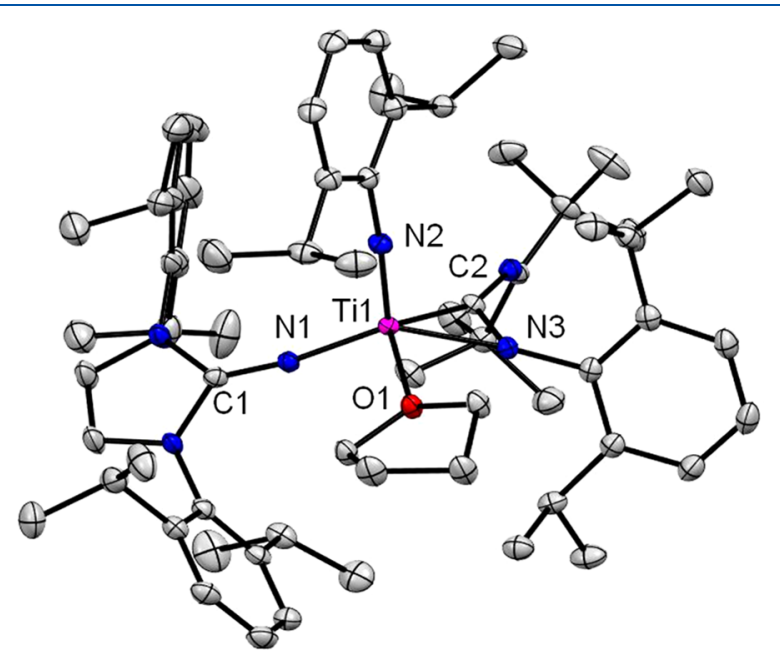

Figure 2. Solid-state molecular structure of 4.THF with $50 \%$ probability ellipsoids. Hydrogen atoms and cocrystallized THF omitted for clarity.

cleavage of the ketimine-guanidinate into imido and anionic iminoacyl fragments. This reduction product is surprising as guanidinates are not known to undergo such reductive fragmentation, but this behavior is reminiscent of the reduction chemistry of early metal $\beta$-diketiminates, which can yield metal imidos. ${ }^{61,62}$ Though it has been shown in formamidinates that addition of external reductant, namely, $\mathrm{Zn}^{0}$ or $\mathrm{Na} / \mathrm{Hg}$, to the reaction mixture of $\mathrm{Li}\left[\mathrm{HC}(\mathrm{NAr})_{2}\right](\mathrm{Ar}=$ phenyl, tolyl $)$ with $\mathrm{Ta}_{2} \mathrm{Cl}_{6}\left(\mathrm{SMe}_{2}\right)_{3}$ leads to the formation of the imido- and iminoacyl-bridged dimer $\left[\mathrm{HC}(\mathrm{NAr})_{2}\right]_{4} \mathrm{Ta}(\mu-\mathrm{NAr})\left(\mu-\eta^{2}\right.$ CNAr) ${ }^{63}$ similarly, reduction of the $\mathrm{Ti}(\mathrm{IV})$ bisamidinate $\left[\mathrm{PhC}\left(\mathrm{NSiMe}_{3}\right)_{2}\right]_{2} \mathrm{TiCl}_{2}$ with $\mathrm{Na} / \mathrm{Hg}$ amalgam in the presence of TMEDA leads to formation of the imido and iminoacyl complexes $\left[\mathrm{PhC}\left(\mathrm{NSiMe}_{3}\right)_{2}\right]_{2} \mathrm{Ti}\left(=\mathrm{NSiMe}_{3}\right)$ and $[\mathrm{PhC}$ $\left.\left(\mathrm{NSiMe}_{3}\right)_{2}\right] \mathrm{Ti}\left[\eta^{2}-\mathrm{Me}_{3} \mathrm{SiNC}(\mathrm{H}) \mathrm{Ph}\right]\left[\eta^{3}-\mathrm{CH}_{2} \mathrm{~N}(\mathrm{Me})-\right.$ $\left.\mathrm{CH}_{2} \mathrm{CH}_{2} \mathrm{~N}(\mathrm{Me})_{2}\right]$, respectively. ${ }^{57,64}$

Inspection of the structural features of $4 \cdot \mathrm{THF}$ show the Ti1-N2 = 1.748(2) $\AA$ bond length and T1-N2-C29= $175.5(2)^{\circ}$ bond angle is within the typical range of titaniumimido parameters (e.g., $\mathrm{Ti}-\mathrm{N}_{\text {imido }}=1.714(2) \AA ; \mathrm{Ti}-\mathrm{N}_{\text {imido }}-$ 
$\mathrm{C}_{\text {imido }}=173.2(1)^{\circ}$ for $\left[\eta^{2}-\mathrm{H}^{i} \operatorname{PrC}=\mathrm{C}\left({ }^{t} \mathrm{Bu}\right) \mathrm{CHC}\left({ }^{t} \mathrm{Bu}\right) \mathrm{NDipp}\right]-$ $\mathrm{Ti}(=\mathrm{NDipp})(\mathrm{OTf})){ }^{65}$ Additionally, the bond metrics of the titanium-imino acyl moiety in $4 \cdot \mathrm{THF}(\mathrm{Ti1}-\mathrm{C} 2=2.122(2) \AA$;

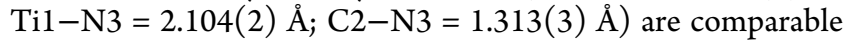
to that known for $\mathrm{Ti}\left(\eta^{2}-\mathrm{MeCNMes}\right)\left[\mathrm{NC}\left({ }^{t} \mathrm{Bu}\right)_{2}\right](\mathrm{Ti}-\mathrm{C}=$ 2.104(6) $\AA$; $\mathrm{Ti}-\mathrm{N}=2.074(5) \AA ; \mathrm{C}-\mathrm{N}=1.282(7) \AA) .{ }^{66} \mathrm{On}$ the other hand, the imidazolin-2-iminato ligand displays a relatively long bond distance to the titanium center (Ti1-N1 $=1.900(2) \AA$ ) despite adopting a near linear coordination mode to the metal $\left(\mathrm{Til}-\mathrm{N} 1-\mathrm{C} 1=169.7(2)^{\circ}\right)$ when compared to $\left[\left(\mathrm{Et}_{2} \mathrm{~N}\right) \mathrm{C}(\mathrm{NDipp})_{2}\right]\left(\mathrm{Im}^{\prime} \mathrm{N}\right) \mathrm{TiCl}_{2}\left(\mathrm{Ti}-\mathrm{N}_{\mathrm{Im}}=\right.$ 1.765(3) $\left.\AA ; \mathrm{Ti}-\mathrm{N}_{\mathrm{Im}}-\mathrm{C}_{\mathrm{Im}}=170.5(3)^{\circ}\right)$. An obtuse $\mathrm{Ti}-\mathrm{N}_{\mathrm{Im}}-$ $\mathrm{C}_{\mathrm{Im}}$ angle is typically suggestive of substantial metal-nitrogen $\pi$-overlap consistent with zwitterionic, imido-type $\mathrm{Ti}=\mathrm{N}-$ $\mathrm{Im}^{+}$bonding stabilized through imidazolium resonance contributions; ${ }^{58,59}$ however, this bonding interaction is likely attenuated by the steric congestion of the titanium center in $\mathbf{4}$. THF. In line with this, the $\mathrm{N} 1-\mathrm{C} 1=1.276(3) \AA$ A bond length of $4 \cdot$ THF is substantially shorter than the corresponding $\mathrm{N}_{\mathrm{Im}}-$ $\mathrm{C}_{\mathrm{Im}}=1.326(5) \AA$ bond in $\left[\left(\mathrm{Et}_{2} \mathrm{~N}\right) \mathrm{C}(\mathrm{NDipp})_{2}\right]\left(\mathrm{Im}^{\prime} \mathrm{N}\right) \mathrm{TiCl}_{2}$ which does display $\mathrm{Ti}=\mathrm{N}-\mathrm{Im}^{+}$bonding character.

The failed attempts at the reduction of $2^{\mathrm{Cl}}$ to lower valent species indicates the key role of the coligands and reaction conditions when reducing early metal complexes. For instance, exchanging the chlorides of $2^{\mathrm{Cl}}$ for triflates in $2^{\mathrm{OTf}}$ leads to smooth formation of $\mathbf{1}$ when using $\mathrm{KC}_{8}$ as a reductant in THF at $-78{ }^{\circ} \mathrm{C}$, whereas reduction of $2^{\mathrm{Cl}}$ under identical conditions leads to a mixture of $1,3,4$, and 5 .

Lastly, all attempts to measure the electrochemical features of 1 by $\mathrm{CV}$, to provide further insight into the redox chemistry of this system, have failed owing to the high reactivity of the complex. For instance, the $\mathrm{CV}$ measurements with $\left[\mathrm{NBu}_{4}\right]$ $\left[\mathrm{PF}_{6}\right]$ as supporting electrolyte have been hampered by the immediate reactivity of 1 with the $\left[\mathrm{NBu}_{4}\right]\left[\mathrm{PF}_{6}\right]$ salt to give a complicated product mixture. Efforts to collect the $\mathrm{CV}$ of $\mathbf{1}$ in THF using anhydrous LiOTf were equally unsuccessful due to an unknown but persistent impurity in the lithium supporting electrolyte despite multiple recrystallization attempts.

Chemical Redox Assessment. In lieu of CV measurements, chemical probes were utilized to provide some insight into the approximate reduction potential range of 1 . For instance, the redox chemistry of benzophenone $\left(\mathrm{Ph}_{2} \mathrm{CO}\right)$ encompasses two consecutive, electrochemically reversible, one-electron reduction events defined by the radical monoanion $\left[\mathrm{Ph}_{2} \mathrm{CO}\right]^{\bullet-}\left(E_{1 / 2}=-2.3 \mathrm{~V}\right.$ vs $\left.\left[\mathrm{Cp}_{2} \mathrm{Fe}\right]^{0 /+}\right)$ followed by formation of the dianion $\left[\mathrm{Ph}_{2} \mathrm{CO}\right]^{2-}\left(E_{1 / 2}=\right.$ $-2.9 \mathrm{~V}$ vs $\left.\left[\mathrm{Cp}_{2} \mathrm{Fe}\right]^{0 /+}\right) .{ }^{60,67}$ Thus, addition of a stoichiometric amount of $\mathrm{Ph}_{2} \mathrm{CO}$ to $\mathbf{1}$ in benzene forms a vibrant purple solution characteristic of the formation of a reduced form of $\mathrm{Ph}_{2} \mathrm{CO}$ (eq 3).

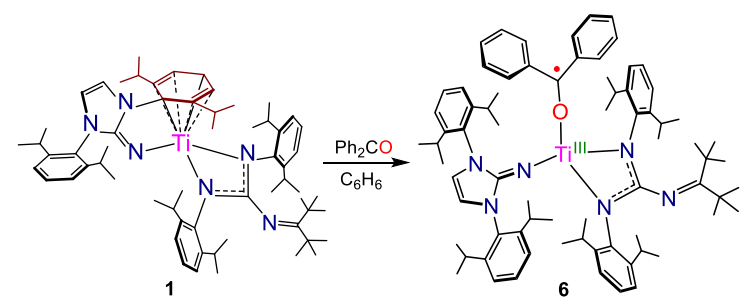

Analysis of this mixture via ${ }^{1} \mathrm{H}$ NMR spectroscopy showed complete consumption of both starting materials and appearance of broad, yet, well-defined resonances in the range of -0.13 to $7.69 \mathrm{ppm}$, suggestive of the formation of a paramagnetic species (Figure S3). To our delight, block shaped, deep-purple crystals grow out of concentrated benzene solutions after $10 \mathrm{~min}$ which are suitable for single crystal X-ray crystallographic analysis. The solid-state molecular structure reveals the formation of the four-coordinate titanium complex $\left({ }^{\text {Ket }}\right.$ guan $)\left(\mathrm{Im}^{\text {Dipp }} \mathrm{N}\right) \mathrm{Ti}\left(\eta^{1}-\mathrm{OCPh}_{2}\right)\left(6 \cdot 2 \mathrm{C}_{6} \mathrm{H}_{6}\right)$ where the benzophenone is observed to adopt an $\eta^{1}-\mathrm{OCPh}_{2}$ form (Til-O1$\left.\mathrm{C} 62=170.13(2)^{\circ}\right)$, residing in the apical position (Figure 3 ).

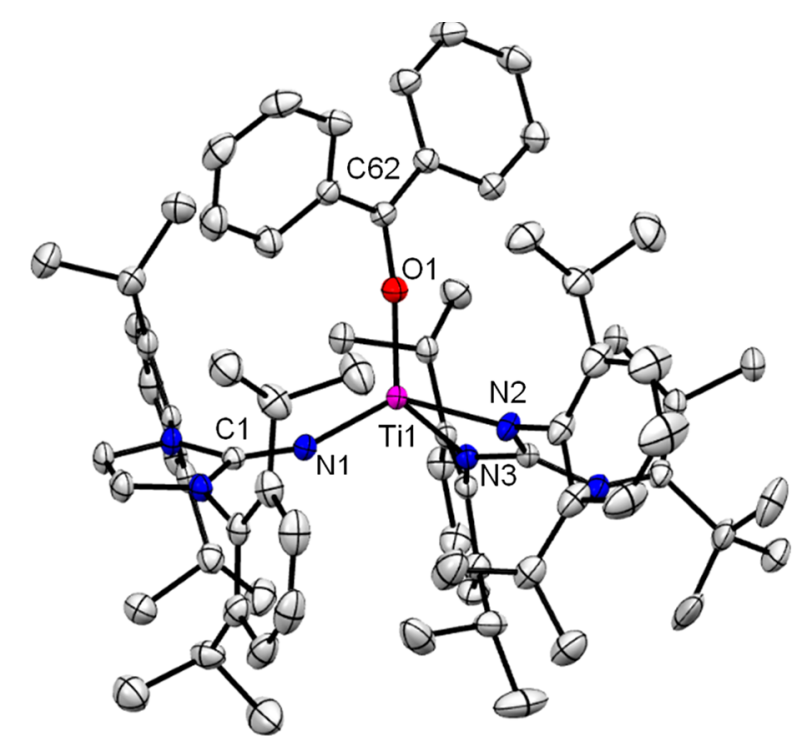

Figure 3. Solid-state molecular structure of $6 \cdot 2 \mathrm{C}_{6} \mathrm{H}_{6}$ with $50 \%$ probability ellipsoids. Hydrogen atoms and cocrystallized $\mathrm{C}_{6} \mathrm{H}_{6}$ omitted for clarity.

The titanium-oxygen bond of $6 \cdot 2 \mathrm{C}_{6} \mathrm{H}_{6}(\mathrm{~T} 1-\mathrm{O} 1=1.857(2)$ $\AA$ ) is significantly shorter than the $\mathrm{Ti}(\mathrm{III})-\mathrm{O}$ bond found in the benzophenone adduct $\left[\mathrm{Cp}^{*}{ }_{2} \mathrm{Ti}\left(\mathrm{OCPh}_{2}\right)\right] \mathrm{BF}_{4}(\mathrm{Ti}-\mathrm{O}=$ $1.988(3) \AA)^{68}$ but similar to the titanium-alkoxide bonds of $\mathrm{Ti}\left(\mathrm{N}^{t} \mathrm{Bu}\right)\left[\mathrm{OCH}(\text { mesityl })_{2}\right]_{2}(\mathrm{py})_{2} \quad(\mathrm{Ti}-\mathrm{O}=1.875(2)-$ $1.889(2) \AA) .{ }^{69}$ Moreover, the carbon-oxygen bond of the $\mathrm{OCPh}_{2}$ ligand in $6 \cdot 2 \mathrm{C}_{6} \mathrm{H}_{6}(\mathrm{C} 62-\mathrm{O} 1=1.328(3) \AA)$ is significantly longer than in free benzophenone $(\mathrm{C}-\mathrm{O}=$ $1.230(0) \AA)^{70}$ and $\left[\mathrm{Cp}_{2}{ }_{2} \mathrm{Ti}\left(\mathrm{OCPh}_{2}\right)\right] \mathrm{BF}_{4}(\mathrm{C}-\mathrm{O}=1.259(5)$ $\AA)^{68}$ but similar to the carbon-oxygen bond in the ketyl complexes $\left[\left(\left({ }^{t \mathrm{Bu}} \mathrm{ArO}\right)_{3} \mathrm{tacn}\right) \mathrm{U}^{\mathrm{IV}}\left(\mathrm{OC} \cdot{ }^{t \mathrm{Bu}} \mathrm{Ph}_{2}\right)\right] \quad(\mathrm{C}-\mathrm{O}=$ $1.334(6) \AA)^{71}$ and $\mathrm{Tp}{ }_{2} \mathrm{U}^{\mathrm{III}}\left(\mathrm{OC} \cdot \mathrm{Ph}_{2}\right)(\mathrm{C}-\mathrm{O}=1.34(1) \AA){ }^{72}$ In addition, the sum of the bond angles around the carbonylic carbon atom in $6 \cdot 2 \mathrm{C}_{6} \mathrm{H}_{6}\left(\sum_{\mathrm{C} 9} \approx 360^{\circ}\right)$ is consistent with $s p^{2}$ hybridization. Overall, the bond metrics in $6 \cdot 2 \mathrm{C}_{6} \mathrm{H}_{6}$ point toward a ketyl-type, monoanionic radical $\left[\mathrm{Ph}_{2} \mathrm{C} \cdot \mathrm{O}\right]^{-}$whose charge is counterbalanced by a trivalent titanium center with the form ( ${ }^{\text {Ket }}$ guan $)\left(\mathrm{Im}^{\mathrm{Dipp}} \mathrm{N}\right) \mathrm{Ti}^{\mathrm{III}}\left(\eta^{1}-\mathrm{OC} \cdot \mathrm{Ph}_{2}\right)$.

In validation of this assessment, the solution EPR spectrum of 6 in toluene at $298 \mathrm{~K}$ gives clear indication of a paramagnetic species (Figure S57). Furthermore, the UV-vis electronic absorption spectrum of 6 in toluene (Figures S43S44) displays an absorbance at $690 \mathrm{~nm}\left(\varepsilon=678 \mathrm{~L} \cdot \mathrm{mol}^{-1}\right.$. $\mathrm{cm}^{-1}$ ), which is similar to the absorption feature observed for $\left.\left[\mathrm{Na}\left(\mathrm{C}_{13} \mathrm{H}_{10} \mathrm{O}\right)(\mathrm{HMPA})_{2}\right]_{2}\right] \quad\left(\mathrm{HMPA}=\mathrm{O}=\mathrm{P}\left(\mathrm{NMe}_{2}\right)_{3}\right)$ in THF $\left(675 \mathrm{~nm}, \varepsilon=5700 \mathrm{~L} \cdot \mathrm{mol}^{-1} \cdot \mathrm{cm}^{-1}\right) .^{73}$ Similarly, the UVvis spectrum of 6 qualitatively matches that known for $(\text { silox })_{3} \mathrm{Ti}\left(\mathrm{OC} \cdot \mathrm{Ph}_{2}\right)\left(\right.$ silox $\left.={ }^{t} \mathrm{Bu}_{3} \mathrm{SiO}^{-}\right)$with a band appearing at $692\left(\varepsilon=1800 \mathrm{~L} \cdot \mathrm{mol}^{-1} \cdot \mathrm{cm}^{-1}\right){ }^{74}$ 
Importantly, low-valent titanium is the cornerstone reagent of McMurry and Pinacol couplings, yet the intermediates formed in these reactions, including the low-valent titanium species themselves, are not well-understood, and organoradicals such as $\mathbf{6}$ are typically invoked as key but fleeting intermediates. $^{21}$ Although titanium-ketyl species have been previously examined in detail, ${ }^{74}$ to the best of our knowledge, 6 represents the first structurally characterized ketyl complex of titanium, thus potentially providing a direct analogue to the intermediates formed in these valuable coupling reactions. Notably, despite its radical character, $\mathbf{6}$ is remarkably stable in benzene solutions at room temperature for several weeks. We postulate that the steric profile of the $3 \mathrm{~N}$-ligand manifold of our $\left[\left({ }^{\text {Ket }} \text { guan }\right)\left(\mathrm{Im}^{\text {Dipp }} \mathrm{N}\right) \mathrm{Ti}\right]^{n+}$ system provides enhanced stability leading to the isolation of $\mathbf{6}$ as the kinetically trapped product. Interestingly, heating benzene solutions of 6 fails to produce the expected coupling products (i.e., $\mathrm{Ph}_{2} \mathrm{CCPh}_{2}$ ) and instead undergoes intramolecular chemistry (vide infra).

The one-electron reduction of benzophenone suggests that 1 is an appreciable reductant. Thus, as further validation of this notion, the lower boundary of the redox capabilities of 1 was probed using pyridine, which has a very low but chemically accessible reduction potential of ca. $-3.1 \mathrm{~V}\left(\mathrm{vs}\left[\mathrm{Cp}_{2} \mathrm{Fe}\right]^{0 /+}\right) .^{75}$ Accordingly, addition of excess pyridine to $\mathbf{1}$ in THF with stirring immediately forms a light green solution from which an insoluble product precipitates.

Single crystals of this compound can be grown by addition of a few drops of pyridine to a THF solution of 1 followed by storage at $-25{ }^{\circ} \mathrm{C}$ for 2 weeks. Single crystal X-ray analysis revealed the formation of the dinuclear complex [( ${ }^{\text {Ket }}$ guan $)$ $\left.\left(\mathrm{Im}^{\text {Dipp }} \mathrm{N}\right) \mathrm{Ti}\right]_{2}\left[\mu^{2}-\left(\mathrm{NC}_{5} \mathrm{H}_{5}-\mathrm{H}_{5} \mathrm{C}_{5} \mathrm{~N}\right)\right]$ (7) (eq 4).

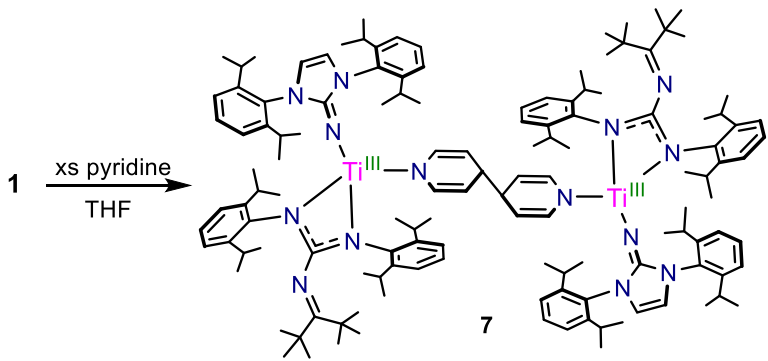

Complex 7.5THF crystallizes in the monoclinic space group $\mathrm{C} 2 / c$ and contains one full $\left[\left({ }^{\mathrm{Ket}}\right.\right.$ guan $\left.)\left(\mathrm{Im}^{\text {Dipp }} \mathrm{N}\right) \mathrm{Ti}\right]\left(\mathrm{NC}_{5} \mathrm{H}_{5}\right)^{-}$ monomer in the asymmetric unit, which resides on a crystallographic inversion center that provides the full dimer upon symmetry generation. The titanium centers are bridged by what initially appears as two terminally coupled pyridine ligands, which adopt a stair-stepped arrangement (Figure 4). Inspection of the metrical parameters within the bridging moiety shows localized bonding indicative of a 1,4dihydropyridine motif $(\mathrm{N} 7-\mathrm{C} 70=1.403(4) \AA$, N7-C74 = 1.399(4) $\AA, C 70-C 71=1.331(5) \AA ̊, C 71-C 72=1.505(5) \AA$, $\mathrm{C} 72-\mathrm{C} 73=1.503(5) \AA$, and $\mathrm{C} 73-\mathrm{C} 74=1.330(5) \AA)$ consistent with the loss of aromaticity. This coupling and ring dearomatization is reminiscent of the chemistry observed between the titanium complex $\mathrm{Ti}(\mathrm{ODipp})_{2}\left(\eta^{2}{ }^{\mathrm{t}}{ }^{\mathrm{BuNCCH}} \mathrm{H}_{2} \mathrm{Ph}\right)$ $\left(\mathrm{CH}_{2} \mathrm{Ph}\right)$ and excess pyridine which yields [Ti(ODipp $\left.)_{2}(\mathrm{py})_{2}\right]_{2}\left[\mu^{2}-\left(\mathrm{NC}_{5} \mathrm{H}_{5}-\mathrm{H}_{5} \mathrm{C}_{5} \mathrm{~N}\right)\right]^{76}$ as well as the reduction of pyridine by $\left\{\left[(\mathrm{Dipp}) \mathrm{NC}\left(\mathrm{CH}_{3}\right)\right]_{2} \mathrm{CH}\right\} \mathrm{Fe}^{\mathrm{I}}\left(\mathrm{C}_{6} \mathrm{H}_{6}\right)$ to give $\left[\left\{\left[(\mathrm{Dipp}) \mathrm{NC}\left(\mathrm{CH}_{3}\right)\right]_{2} \mathrm{CH}\right\} \mathrm{Fe}^{\mathrm{II}}\right]_{2}\left[\mu^{2}-\left(\mathrm{NC}_{5} \mathrm{H}_{5}-\right.\right.$ $\left.\left.\mathrm{H}_{5} \mathrm{C}_{5} \mathrm{~N}\right)\right]^{75}$ Thus, 7 can be described as the Ti(III) product of the reductive $\mathrm{C}-\mathrm{C}$ coupling of pyridine. In line with this,

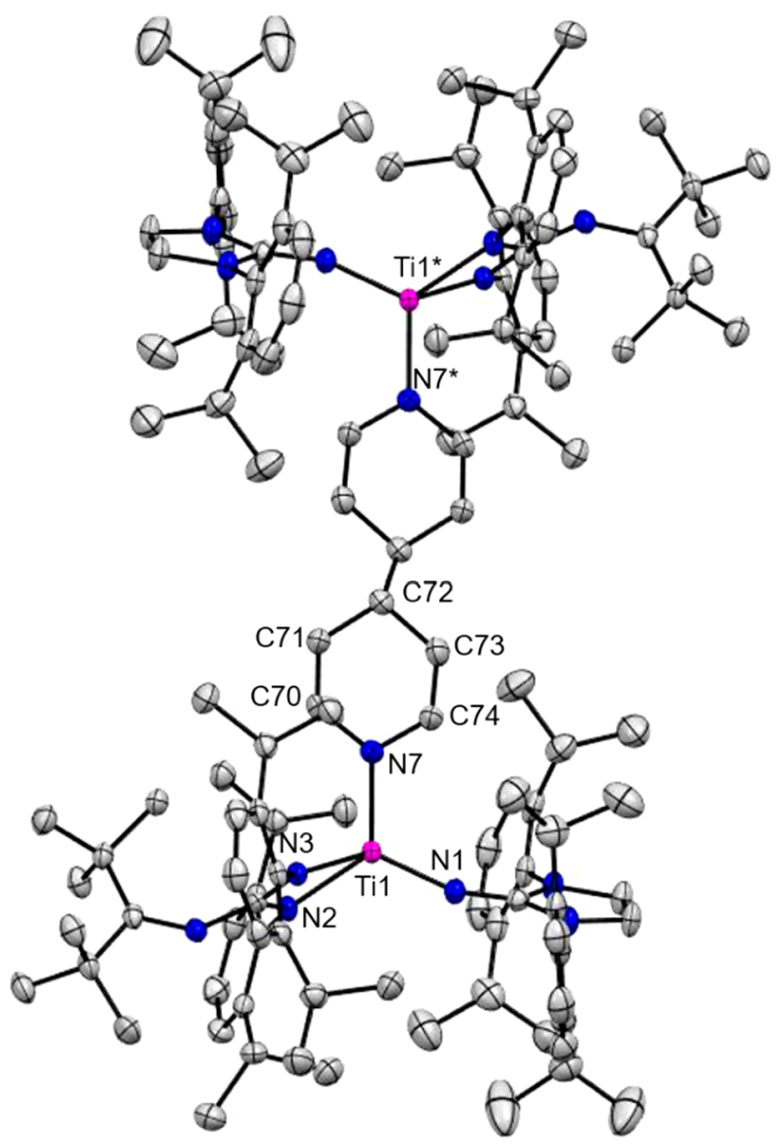

Figure 4. Solid-state molecular structure of $7 \cdot 5 \mathrm{THF}$ with $50 \%$ probability ellipsoids. Hydrogen atoms and cocrystallized THF omitted for clarity. Asterisks denote symmetry generated atoms.

the solution EPR spectrum of 7 in toluene at $298 \mathrm{~K}$ shows a highly isotropic signal at $g=1.957$ (Figure S58) similar to that observed for 3 , signifying a $\mathrm{Ti}(\mathrm{III})$ metal-based radical. ${ }^{52}$ Consequently, paramagnetic broadening essentially renders the complex NMR silent in the ${ }^{1} \mathrm{H}$ NMR spectrum at room temperature in py- $d_{5}$.

Taken together, the reduction of benzophenone and pyridine by 1 provides an approximate range for the redox potential of 1 between ca. -2.3 to $-3.1 \mathrm{~V}\left(\mathrm{vs}\left[\mathrm{Cp}_{2} \mathrm{Fe}\right]^{0 /+}\right)$. In comparison to the $\mathrm{Ti}(\mathrm{II}) /(\mathrm{III})$ redox couple of $\mathrm{Tp}_{2} \mathrm{Ti}(\mathrm{Tp}=$ hydrotris(pyrazol-1-yl)borate) $\left(E_{1 / 2}=-1.84 \mathrm{~V}\right.$ vs $\left.\left[\mathrm{Cp}_{2} \mathrm{Fe}\right]^{0 /+}\right),{ }^{77}$ the potential of $\mathbf{1}$ is considerably lower. Of course, these chemical assays are only rough approximations of the $\mathrm{Ti}(\mathrm{II})$ redox character of $\mathbf{1}$ as they do not take into account other thermodynamic parameters, which can contribute to the observed electron-transfer reactivity. Nonetheless, these tests with benzophenone and pyridine do illustrate that $\mathbf{1}$ is an operative and potent reductant which effectively behaves as a $\mathrm{Ti}(\mathrm{II})$ synthon.

$\pi$-Acid Reactivity. As noted above, the addition of excess $\mathrm{CO}$ to a solution of $\mathbf{1}$ in benzene leads to the formation of the diamagnetic $\mathrm{Ti}$ (II) dicarbonyl complex 8. ${ }^{51}$ In our exploration of the redox behavior and $\mathrm{Ti}$ (II) synthon character of $\mathbf{1}$, its reactivity with other $\pi$-acids was examined. Isocyanides have been shown capable of stabilizing $\mathrm{Ti}(\mathrm{II})$ complexes, $^{78-81}$ and as $\mathrm{C} \equiv \mathrm{N}-\mathrm{R}$ is isoelectronic and isolobal to $\mathrm{CO}$, this reagent class seemed an appropriate choice for the attempted isolation of a $\mathrm{Ti}(\mathrm{II})$ product. Treatment of a brown, thawing benzene solution of 1 with 2 equiv of $\mathrm{C} \equiv \mathrm{NCy}$ ( $\mathrm{Cy}=$ cyclohexyl) 
results in a modest darkening of the solution within a few minutes. Removal of the volatiles affords a dark-brown material that upon dissolution in $\mathrm{Et}_{2} \mathrm{O}$ and storage at $-25{ }^{\circ} \mathrm{C}$ for 2 days produces a crop of small, yellow crystals. This contrasts the dark red color of $\mathbf{8}$, and the ${ }^{1} \mathrm{H}$ NMR spectrum of the product in $\mathrm{C}_{6} \mathrm{D}_{6}$ reveals the formation of a paramagnetic compound with very broad, nondescriptive resonances appearing from 0.7 to $7.4 \mathrm{ppm}$ (Figure S4).

The synchrotron radiation X-ray crystallographic analysis of the yellow crystals revealed the formation of the $\mathrm{Ti}(\mathrm{III})$ cyanide complex ( ${ }^{\text {Ket }}$ guan $)\left(\operatorname{Im}^{\text {Dipp }} \mathrm{N}\right) \mathrm{Ti}(\mathrm{CN})(\mathrm{CNCy})$ (9. $\mathrm{Et}_{2} \mathrm{O}$ ) (eq 5), which crystallizes in the $P 2_{1} / n$ space group
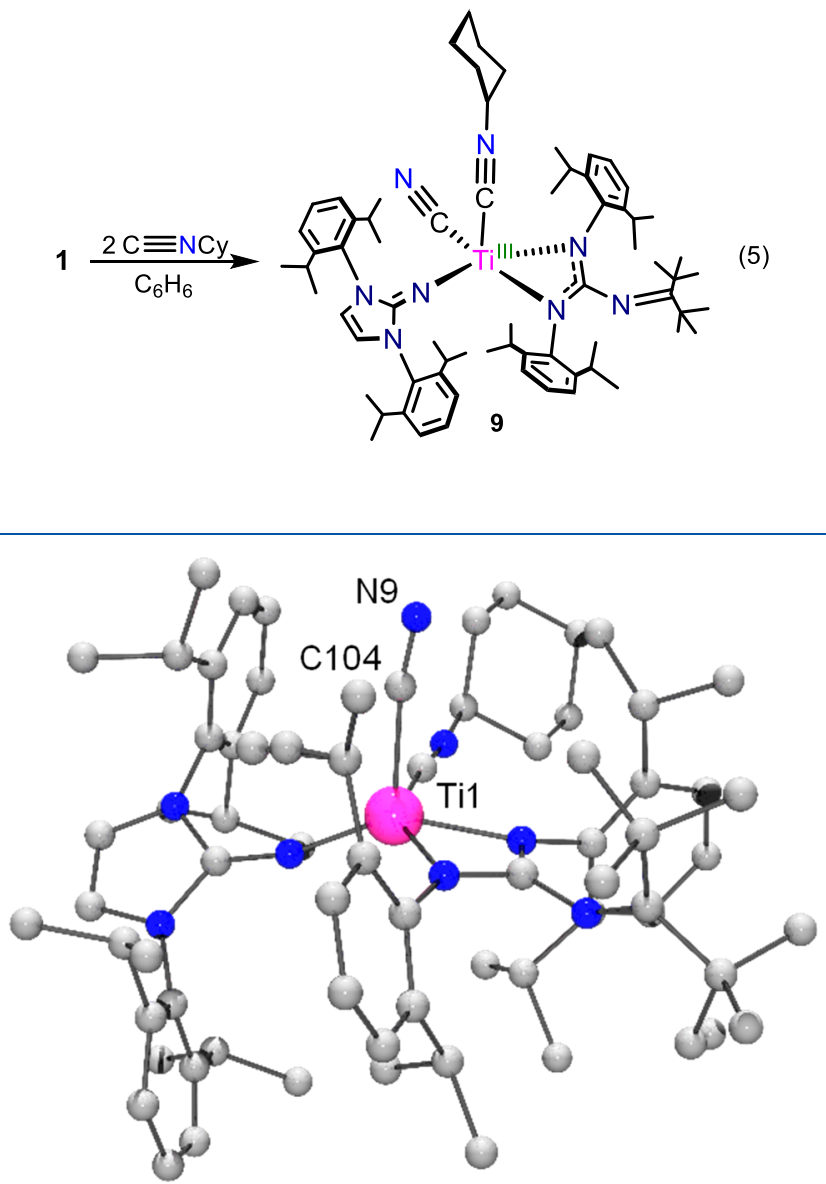

Figure 5. Solid-state molecular structure of $9 \cdot \mathrm{Et}_{2} \mathrm{O}$ presented as ball and stick. Hydrogen atoms and cocrystallized $\mathrm{Et}_{2} \mathrm{O}$ omitted for clarity.

(Figure 5). In the solid-state, 9 exhibits severe positional disorder whereby two full molecules are superimposed in slightly offset orientations pivoted at the titanium center (Figure S63), precluding in-depth metrical analysis of the structural parameters. Despite the significant molecular disorder, the titanium center and cyanide moiety are ordered, providing some structural information.

Interestingly, 9 is a relatively rare example of a terminally bound titanium-cyanide complex as only a handful of structurally characterized compounds have been reported. ${ }^{82-87}$ The titanium-cyanide bond length of 9 (Ti1-C104 = 2.169(6) $\AA)$ is slightly shorter than that of the $\mathrm{Ti}(\mathrm{III})$-cyanides $\left[\mathrm{NEt}_{4}\right]_{3}\left[\mathrm{Ti}(\mathrm{CN})_{6}\right](\mathrm{Ti}-\mathrm{C}=2.20 \AA \text { (avg.) })^{83}$ and $\left[\mathrm{NEt}_{4}\right]$ $\left[\mathrm{Tp} * \mathrm{Ti}(\mathrm{CN})_{3}\right](\mathrm{Ti}-\mathrm{C}=2.18 \AA$ (avg. $\left.)\right)^{84}$ but exhibits a cyanide $\mathrm{C}-\mathrm{N}$ bond length $(\mathrm{C} 104-\mathrm{N} 9=1.154(5) \AA)$ within the range found for those complexes $(1.139(3)-1.166(4) \AA)$.

The infrared spectrum of 9 ( $\mathrm{KBr}$ pellet) (Figure $\mathrm{S} 61$ ) displays a $\nu_{\mathrm{CN}}=2137 \mathrm{~cm}^{-1}$ that is higher than the range of $\left[\mathrm{NEt}_{4}\right]_{3}\left[\mathrm{Ti}(\mathrm{CN})_{6}\right]\left(\nu_{\mathrm{CN}}=2017 \mathrm{~cm}^{-1}\right)^{83}$ and $\mathrm{K}_{3}\left[\mathrm{Ti}(\mathrm{CN})_{6}\right]$ $\left(\nu_{\mathrm{CN}}=2088 \mathrm{~cm}^{-1}\right)^{83}$ but near that found for $\left[\mathrm{NEt}_{4}\right]\left[\mathrm{Tp}^{*} \mathrm{Ti}-\right.$ $\left.(\mathrm{CN})_{3}\right]\left(\nu_{\mathrm{CN}}=2116\right.$ and $\left.2103 \mathrm{~cm}^{-1}\right),{ }^{84}$ while the cyano stretching frequency of its coordinated CNCy ligand $\left(\nu_{\mathrm{CN}}=\right.$ $\left.2207 \mathrm{~cm}^{-1}\right)$ is greater than that reported for the $\mathrm{Ti}(\mathrm{III})$ metallocenes $\mathrm{Cp}_{2}{ }_{2} \mathrm{Ti}(\mathrm{CNXy})\left(\mathrm{CCSiMe}{ }_{3}\right)(\mathrm{Xy}=\mathrm{xylyl})\left(\nu_{\mathrm{CN}}=\right.$ $\left.2115 \mathrm{~cm}^{-1}\right)^{80}$ and $\mathrm{CpTi}(\mathrm{CNXy}) \mathrm{I}_{2}\left(\nu_{\mathrm{CN}}=2156 \mathrm{~cm}^{-1}\right) .^{78}$ Finally, the EPR spectrum of 9 in toluene and as a solid at 298 $\mathrm{K}$ exhibits complicated anisotropic signals in agreement with a $\mathrm{Ti}$ (III) center in a low-symmetry ligand environment (Figures S59-S60).

The unexpected formation of 9 from the isocyanide N-Cy bond cleavage is not without precedent in the literature. For instance, addition of 3 equiv of $\mathrm{C} \equiv \mathrm{N}^{t} \mathrm{Bu}$ to $\mathrm{Cp}^{*}{ }_{2} \mathrm{Ti}$ $\left[\left(\mathrm{CH}_{2}\right)_{2} \mathrm{CH}^{i} \mathrm{Pr}\right]$ affords the half-sandwich enediamidate $\mathrm{Cp}{ }^{*} \mathrm{Ti}\left[\left(\mathrm{N}^{t} \mathrm{BuC}\right)_{2}\left(\mathrm{CH}_{2}\right)_{2} \mathrm{CH}\left({ }^{i} \mathrm{Pr}\right)\right](\mathrm{CN})$ bearing a cyanide ligand. ${ }^{82}$ Additionally, treatment of vanadocene $\left(\mathrm{Cp}_{2}{ }_{2} \mathrm{~V}\right)$ with cyclohexyl cyanide leads to the formation of an intermediate $\mathrm{V}$ (II) species that subsequently undergoes free radical isocyanide dealkylation to generate the $\mathrm{V}$ (III) complex $\mathrm{Cp} *{ }_{2} \mathrm{~V}(\mathrm{CN})(\mathrm{CNCy})$ concomitant with the formation of cyclohexane. ${ }^{88}$ This suggests that $\mathbf{1}$, akin to $\mathrm{Cp}_{2}^{*} \mathrm{~V}$, in its reaction with $\mathrm{C} \equiv \mathrm{NCy}$ is acting as a reductant, which consequently leads to the observed bond scission through free-radical activation.

The formation of 9 prompted us to examine the reactivity of 1 with nitriles to test for similar behavior. As such, addition of a slight excess of $\mathrm{N} \equiv \mathrm{C}^{t} \mathrm{Bu}$ to a thawing benzene solution of 1 leads to the formation of a homogeneous dark-brown solution after $12 \mathrm{~h}$. Removal of the volatiles and recrystallization from $\mathrm{Et}_{2} \mathrm{O}$ yields light orange crystals after storage for 2 days at -25 ${ }^{\circ} \mathrm{C}$. In contrast to $9,{ }^{1} \mathrm{H}$ and ${ }^{13} \mathrm{C}\left\{{ }^{1} \mathrm{H}\right\}$ NMR spectral analysis revealed the formation of a diamagnetic product with $C_{1}$ symmetry in solution possessing spectral features similar to 5 , indicative of a cyclometalated product.

The solid-state molecular structure as revealed by single crystal X-ray analysis is displayed in (Figure 6) and shows the formation of the metallacycle $\mathrm{Ti}(\mathrm{IV})$-ketimide complex $\left(\mathrm{Im}^{\text {Dipp }} \mathrm{N}\right)\left[(\mathrm{DippN})\left(2-{ }^{i} \mathrm{PrC}_{6} \mathrm{H}_{3}-6-\left(\eta^{1}-\mathrm{CH}_{3} \mathrm{CHCH}_{2}\right) \mathrm{N}\right) \mathrm{C}-\right.$ $\left.\left(\mathrm{NC}^{t} \mathrm{Bu}_{2}\right)\right] \mathrm{Ti}\left[\mathrm{NC}(\mathrm{H})^{t} \mathrm{Bu}\right]$ (10) (eq 6). Complex 10. $\mathrm{Et}_{2} \mathrm{O}$

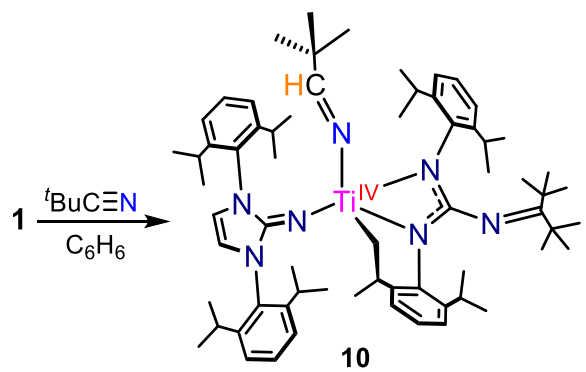

crystallizes in the triclinic space group $P \overline{1}$ with two full molecules in the asymmetric unit accompanied by a molecule of $\mathrm{Et}_{2} \mathrm{O}$. One of the titanium molecules exhibits nonmetalated/ cyclometalated disorder at two of its Dipp groups, and thus only the metrical parameters of the ordered molecule are presented.

The Ti-ketimide bond length of $10 \cdot \mathrm{Et}_{2} \mathrm{O}(\mathrm{Ti}-\mathrm{N}=1.842(2)$ $\AA)$ is unremarkable and falls within the established range of 


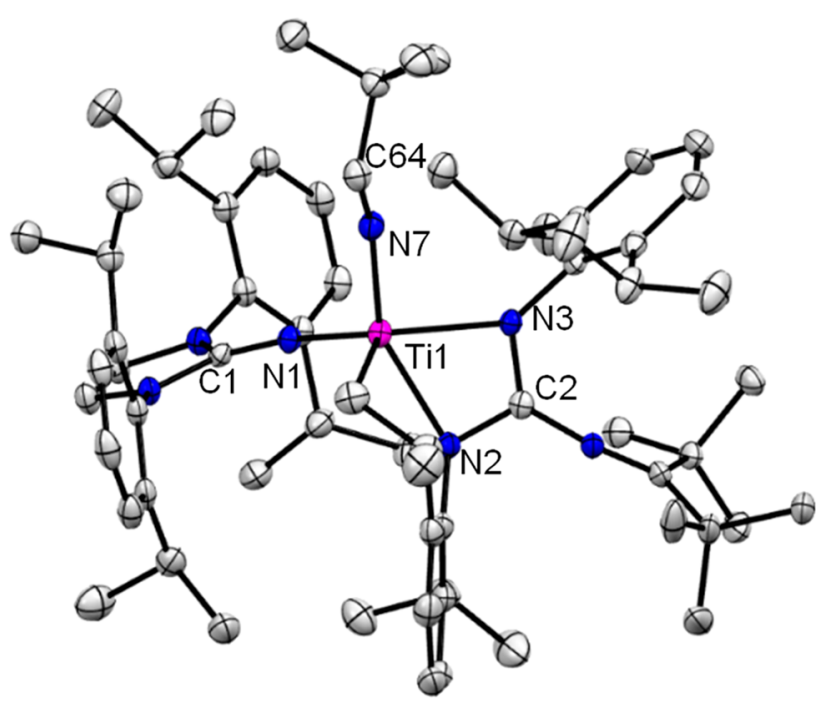

Figure 6. Solid-state molecular structure of $10 \cdot \mathrm{Et}_{2} \mathrm{O}$ with $50 \%$ probability ellipsoids. Hydrogen atoms and cocrystallized $\mathrm{Et}_{2} \mathrm{O}$ omitted for clarity.

titanium-ketimide bonds such as those found in TiCl$\left(\mathrm{NC}^{t} \mathrm{Bu}_{2}\right)_{3}(\mathrm{Ti}-\mathrm{N}=1.82(1)-1.836(8) \AA)^{89}$ and $\{[(\mathrm{Dipp})-$ $\left.\left.\mathrm{NC}\left(\mathrm{CH}_{3}\right)\right]_{2} \mathrm{CH}\right\} \mathrm{Ti}\left(\mathrm{NCPh}_{2}\right)\left\{\mathrm{N}\left[\mathrm{P}\left(\mathrm{CH}_{2}{ }^{t} \mathrm{Bu}\right) \mathrm{C}_{6} \mathrm{H}_{2}{ }^{t} \mathrm{Bu}_{3}\right]\right\} \quad(\mathrm{Ti}-$ $\mathrm{N}=1.918(3) \AA) .{ }^{90}$ Furthermore, as compared to other titanium-ketimide complexes, which commonly exhibit more linear coordination modes of the ketimide ligand (cf. $\left.\mathrm{TiCl}\left(\mathrm{NC}^{t} \mathrm{Bu}_{2}\right)_{3}: \mathrm{Ti}-\mathrm{N}-\mathrm{C}=170.8(7)-175.6(7)^{\circ}\right)$, the Til$\mathrm{N} 7-\mathrm{C} 64=155.8(2)^{\circ}$ bond angle in $10 \cdot \mathrm{Et}_{2} \mathrm{O}$ is rather bent, a likely consequence of the steric congestion around the titanium center. In line with this, the coordination of the $\mathrm{Im}^{\text {Dipp }} \mathrm{N}^{-}$ group in $10 \cdot \mathrm{Et}_{2} \mathrm{O}$ is also bent $\left(\mathrm{Til}-\mathrm{N} 1-\mathrm{C} 1=167.0(2)^{\circ}\right)$, yet slightly more linear than that of the corresponding angle in 3 ( Til $\left.-\mathrm{N} 1-\mathrm{C} 1=158.2(2)^{\circ}\right)$, though the $\mathrm{Ti}-\mathrm{N}_{\text {Im }}$ bond length of Til-N1 $=1.842(2) \AA$ in $10 \cdot \mathrm{Et}_{2} \mathrm{O}$ is equivalent to the Til$\mathrm{N} 1=1.852(2) \AA$ bond of 3 within the $3 \sigma$-criterion.

Complex 10 is isolated in $66 \%$ yield, and its formation suggests the initial reduction of a coordinated nitrile ligand to generate a $\mathrm{Ti}(\mathrm{III})$ radical nitrile species, which abstracts an $\mathrm{H}$ atom from a pendant isopropyl methyl group. Consequently, this would form a radical isopropyl fragment that undergoes oxidative bond coupling with the titanium center, rendering the observed $\mathrm{Ti}(\mathrm{IV})$ metallacycle $\mathbf{1 0}$. This obviously deviates from the synthesis of 9 , which undergoes isocyanide $\mathrm{CN}-\mathrm{R}$ bond scission. If the proposed radical mechanism in the formation of $\mathbf{1 0}$ is the operative pathway, then it is conceivable that similar chemistry could be elicited with the $\mathrm{Ti}(\mathrm{III})$ organoradical ketyl complex 6.

To test this, a toluene solution of 6 was heated at $60{ }^{\circ} \mathrm{C}$ for $24 \mathrm{~h}$ leading to the change of the purple solution to give a paleyellow solution and formation of a new diamagnetic product. The ${ }^{1} \mathrm{H}$ NMR spectrum of the new product is complicated (Figure S9), suggestive of $C_{1}$ symmetry in solution, with spectral features reminiscent of the metallacycles $\mathbf{5}$ and $\mathbf{1 0}$. Indeed, X-ray crystallographic analysis of single crystals grown from $\mathrm{Et}_{2} \mathrm{O}$ at $-25{ }^{\circ} \mathrm{C}$ shows the formation of the $\mathrm{Ti}(\mathrm{IV})$ alkoxide metallacycle $\left(\mathrm{Im}^{\text {Dipp }} \mathrm{N}\right)\left[(\mathrm{DippN})\left(2-{ }^{i} \mathrm{PrC}_{6} \mathrm{H}_{3}-6-\left(\eta^{1}-\right.\right.\right.$ $\left.\left.\left.\mathrm{CH}_{3} \mathrm{CHCH}_{2}\right) \mathrm{N}\right) \mathrm{C}\left(\mathrm{NC}^{t} \mathrm{Bu}_{2}\right)\right] \mathrm{Ti}\left(\mathrm{OCPh}_{2} \mathrm{H}\right)$ (11) (eq 7).

Complex 11.2Et ${ }_{2} \mathrm{O}$ crystallizes in the $P \overline{1}$ space group with two full molecules in the asymmetric unit and is shown in Figure 7. The structural parameters of the two molecules are
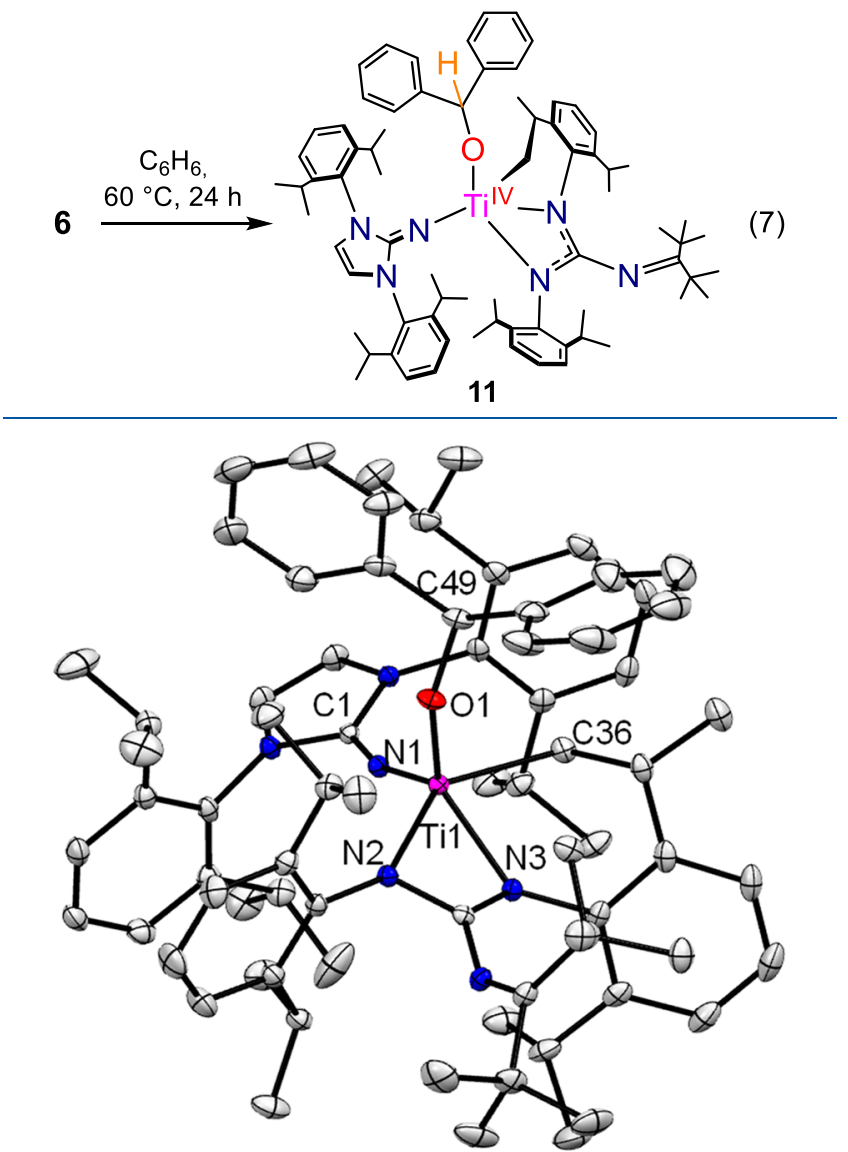

Figure 7. Solid-state molecular structure of $11 \cdot 2 \mathrm{Et}_{2} \mathrm{O}$ with $50 \%$ probability ellipsoids. Hydrogen atoms and cocrystallized $\mathrm{Et}_{2} \mathrm{O}$ omitted for clarity.

nearly identical, and the metrical details of only one are discussed for clarity. By far, the most salient feature of $\mathbf{1 1}$. $2 \mathrm{Et}_{2} \mathrm{O}$ is the structural changes that are observed at the reduced benzophenone moiety. The Ti1-O1 = 1.824(1) $\AA$ bond length in $11 \cdot 2 \mathrm{Et}_{2} \mathrm{O}$ is slightly shorter than that found in 6 $(\mathrm{T} 1-\mathrm{O} 1=1.856(2) \AA)$ while the $\mathrm{O} 1-\mathrm{C} 1=1.416(2) \AA$ bond is significantly elongated in comparison to the corresponding bond in $6(\mathrm{O} 1-\mathrm{C} 62=1.328(3) \AA)$. Furthermore, the sum of the bond angles around the $\mathrm{C} 1$ atom in $11 \cdot 2 \mathrm{Et}_{2} \mathrm{O}\left(\sum_{\mathrm{C} 1} \approx\right.$ $334.5^{\circ}$ ) indicate $s p^{3}$-hybridization.

In total, these structural features are consistent with full reduction of the benzophenone group to a diphenylmethyl alkoxide ligand. In line with this, the parameters of the alkoxide ligand in $11 \cdot 2 \mathrm{Et}_{2} \mathrm{O}$ are comparable to those found for the bis(mesityl)methyl alkoxide groups in the $\mathrm{Ti}(\mathrm{IV})$ complex $\mathrm{Ti}\left(\mathrm{N}^{t} \mathrm{Bu}\right)\left[\mathrm{OCH}(\text { mesityl })_{2}\right]_{2}(\mathrm{py})_{2}(\mathrm{Ti}-\mathrm{O}=1.875(2) \AA ̊ \mathrm{O}-\mathrm{C}$ $=1.402(4) \AA) .{ }^{69}$

The formation of $\mathbf{1 1}$ is somewhat surprising as the molecule neither eliminates tetraphenylethylene, as the expected McMurry coupling product, nor is radical coupling between the benzophenone ketyls observed as in the complexes $\mathrm{Ti}$ (OC. $\left.\mathrm{Ph}_{2}\right)(\text { silox })_{3}$ and $\mathrm{U}\left(\mathrm{OC} \cdot \mathrm{Ph}_{2}\right)\left[\mathrm{N}\left(\mathrm{SiMe}_{3}\right)_{2}\right]_{3}$, which both undergo $\mathrm{C}-\mathrm{C}$ radical bond coupling to give the dinuclear compounds $(\mathrm{L})_{3} \mathrm{M}\left[\mathrm{OC}(\mathrm{Ph})\left(\mathrm{C}_{6} \mathrm{H}_{4}\right) \mathrm{C}(\mathrm{Ph})_{2} \mathrm{O}\right] \mathrm{M}(\mathrm{L})_{3} \quad(\mathrm{M}=$ $\mathrm{U}, \mathrm{L}=\mathrm{N}(\mathrm{SiMe})_{3} ; \mathrm{M}=\mathrm{Ti}, \mathrm{L}=$ silox $) .{ }^{74,91}$ However, the $\mathrm{Ti}(\mathrm{III})$ ketyl complexes $\mathrm{Ti}(\mathrm{OC} \cdot \mathrm{MeR})(\text { silox })_{3}(\mathrm{R}=\mathrm{H}, \mathrm{Me})$ do undergo an $\mathrm{H}$ atom abstraction event to give the $\mathrm{Ti}(\mathrm{IV})$ alkoxides $\mathrm{Ti}(\mathrm{OCHMeR})(\text { silox })_{3} .^{74}$ 
Altogether, the formation of metallacycles 10 and 11 indicate a convergent reactivity profile between the addition of pivalonitrile and benzophenone to $\mathbf{1}$, implicating a $\mathrm{Ti}(\mathrm{III})$ organoradical species as key intermediate generated through the one-electron reduction of the substrate by a highly reducing $\mathrm{Ti}(\mathrm{II})$-synthon. The reactivity of 1 toward $\pi$-acids such as CO, isocyanide, and nitriles is apparently not straightforward and gives rise to a number of $\mathrm{Ti}(\mathrm{II}) / \mathrm{Ti}(\mathrm{III}) /$ $\mathrm{Ti}(\mathrm{IV})$ complexes which demonstrates that the redox chemistry of LVEMs is rich and highly varied.

Finally, in an attempt to displace the intramolecular Ti-arene capping interaction of $\mathbf{1}$, a solution of the compound was made with $o$-difluorobenzene $\left(\mathrm{C}_{6} \mathrm{H}_{4} \mathrm{~F}_{2}\right)$. We reasoned that the increased $\pi$-acidity of the partially fluorinated benzene molecule would potentially favor intermolecular arene capture and reduction to give a complex of the type "( ${ }^{\text {Ket }}$ guan)$\left(\mathrm{Im}^{\text {Dipp }} \mathrm{N}\right) \mathrm{Ti}\left(\mathrm{C}_{6} \mathrm{H}_{4} \mathrm{~F}_{2}\right)$ ", though it has been shown in the literature that LVEMs are capable of reductively cleaving $\mathrm{C}-\mathrm{F}$ bonds to give new fluoride products. ${ }^{92}$

Dissolving 1 in neat $\mathrm{C}_{6} \mathrm{H}_{4} \mathrm{~F}_{2}$ gradually gives way to a yellow color over a $12 \mathrm{~h}$ period (eq 8). Removal of the volatiles and

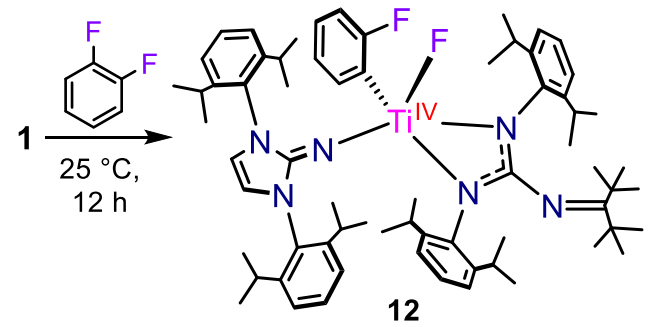

extraction into $\mathrm{Et}_{2} \mathrm{O}$, followed by concentration and storage at $-25{ }^{\circ} \mathrm{C}$ yields a crop of yellow crystals after 2 days. The ${ }^{1} \mathrm{H}$, ${ }^{13} \mathrm{C}\left\{{ }^{1} \mathrm{H}\right\}$, and ${ }^{19} \mathrm{~F}\left\{{ }^{1} \mathrm{H}\right\}$ NMR spectra showed the formation of a diamagnetic product with resonances appearing in the ${ }^{1} \mathrm{H}$ NMR spectrum (Figure S13) from 0.70 to $7.60 \mathrm{ppm}$ with a spectral profile consistent with $C_{1}$ symmetry in solution, indicative of $\mathrm{C}-\mathrm{F}$ bond cleavage and the formation of ( ${ }^{\text {Ket }}$ guan $)\left(\operatorname{Im}{ }^{\text {Dipp }} \mathrm{N}\right) \mathrm{Ti}(\mathrm{F})\left(\mathrm{C}_{6} \mathrm{H}_{4} \mathrm{~F}\right)(\mathbf{1 2})$. The ${ }^{19} \mathrm{~F}\left\{{ }^{1} \mathrm{H}\right\}$ NMR spectrum displays a singlet appearing at $-171.4 \mathrm{ppm}$ corresponding to the ortho-fluorophenyl resonance, while a signal attributable to the Ti-F fluorine atom was not observed up to 900 ppm (Figure S14).

Crystals of $\mathbf{1 2}$ were analyzed using synchrotron radiation, yet, the crystals diffracted weakly and only provided data sufficient for atom connectivity, precluding any metrical analyses (Figure 8). Nonetheless, the solid-state molecular structure of 12 conforms to the $C_{1}$ solution-phase symmetry observed by NMR analyses.

Two-Electron Reactivity and Small Molecule Activation. The reactivity of LVEMs (or their synthon equivalents) with chalcogenides or pnictogen group transfer reagents to give terminally bound, metal-ligand multiply bonded complexes of the type $\mathrm{M}=\mathrm{E}(\mathrm{E}=$ chalcogen, $\mathrm{N}-\mathrm{R})$ is well documented in the literature. ${ }^{56,64,93-102}$ For instance, addition of $S_{8}$ to the $\mathrm{Zr}(\mathrm{II})$ metallocene $\mathrm{Cp}^{*}{ }_{2} \mathrm{Zr}(\mathrm{CO})_{2}$ in the presence of pyridine produces the $\mathrm{Zr}(\mathrm{IV})$ sulfide complex $\mathrm{Cp}^{*} \mathrm{Zr}(\mathrm{S})(\mathrm{py}),{ }^{95,96}$ while addition of $\mathrm{N}_{2} \mathrm{O}$ to the $\mathrm{Ti}(\mathrm{II})$ synthon $\mathrm{Cp}^{*}{ }_{2} \mathrm{Ti}-$ $\left(\mathrm{H}_{2} \mathrm{CCH}_{2}\right)$ in a mixture of THF and pyridine affords the $\mathrm{Ti}(\mathrm{IV})$ oxo $\mathrm{Cp}{ }_{2} \mathrm{Ti}(\mathrm{O})(\mathrm{py}){ }^{93}$ In both of these examples, pyridine coordination is needed to prevent chalcogenide bridging. Moreover, similar reactivity toward chalcogenides is observed in the titanium complexes $\{[\mathrm{PhC}$ -

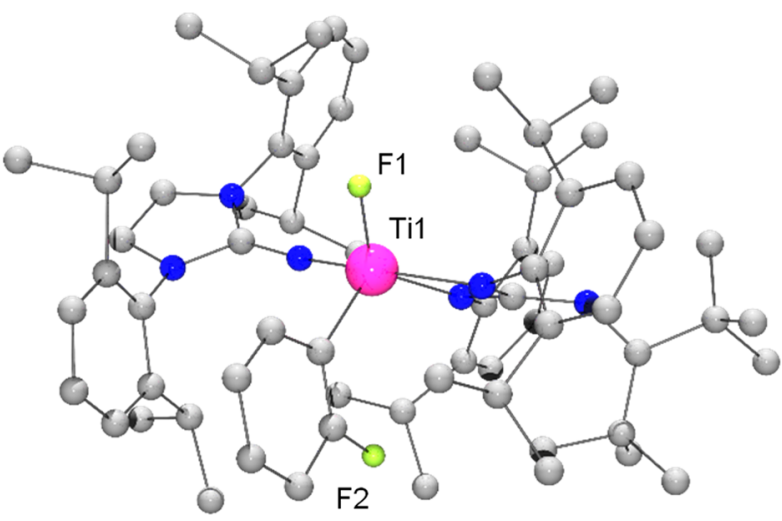

Figure 8. Solid-state molecular structure of $\mathbf{1 2} \cdot \mathrm{Et}_{2} \mathrm{O}$ presented as ball and stick. Hydrogen atoms and cocrystallized $\mathrm{Et}_{2} \mathrm{O}$ omitted for clarity.

$\left.\left.\left(\mathrm{NSiMe}_{3}\right)_{2}\right]_{2} \mathrm{Ti}\right\}_{2}\left(\mathrm{~N}_{2}\right)$ and $\mathrm{Tp}_{2} \mathrm{Ti}^{64,97}$ Alternatively, titanium imidos can be synthesized through a host of reactions including the treatment of $\mathrm{Ti}(\mathrm{II})$ sources with hydrazine or organoazide reagents. ${ }^{56,99,103}$

Leveraging the two-electron redox chemistry of 1 , a series of chalcogenide and imido complexes were targeted in order to assess the efficacy of our $\left[\left({ }^{\text {Ket }} \text { guan }\right)\left(\mathrm{Im}^{\text {Dipp }} \mathrm{N}\right) \mathrm{Ti}\right]^{n+}$ platform to access and stabilize metal-ligand multiple bonds. Treatment of benzene or toluene solutions of 1 with $\mathrm{N}_{2} \mathrm{O}, 1 / 8$ th equiv of $S_{8}$, or excess elemental selenium leads to the formation of the respective $\mathrm{Ti}(\mathrm{IV})$ chalcogenides (Ket guan) $\left(\mathrm{Im}^{\mathrm{Dipp}} \mathrm{N}\right) \mathrm{Ti}(\mathrm{E})$ (E $=\mathrm{O}$ (13), $\mathrm{S}(14)$, Se (15)) (Scheme 1) as dark maroon to green solids. The reaction between 1 and $\mathrm{N}_{2} \mathrm{O}$ to give 13 is clean; however, use of elemental sulfur or selenium leads to several side products in the reactions of 14 and $\mathbf{1 5}$. These side products can be eliminated or greatly diminished by the use of 1 equiv of $\mathrm{S}=\mathrm{PPh}_{3}$ or $\mathrm{Se}=\mathrm{PPh}_{3}$ to give the sulfido and selenido complexes in improved yields of 61 and $71 \%$, respectively. It must be noted that the use of $\mathrm{S}=\mathrm{PPh}_{3}$ and $\mathrm{Se}=\mathrm{PPh}_{3}$ as transfer reagents generate $\mathrm{PPh}_{3}$, which we have found difficult to completely remove from samples of 14 and 15 due to comparable solubility properties. Additionally, treatment of 1 with excess propylene sulfide leads to the formation of the $\mathrm{Ti}(\mathrm{IV})$ disulfide (Ket $\left.{ }^{\text {guan }}\right)\left(\operatorname{Im}{ }^{\text {Dipp }} \mathrm{NTi}\left(\eta^{2}-\mathrm{S}_{2}\right)\right.$ (16) (Scheme 1). (N.B., Compound 14 can by synthesized from the comproportionation reaction of 1 and 16, albeit slowly, or from the addition of elemental mercury to 16). The reaction between 1 and tellurium or $\mathrm{Te}=\mathrm{PPh}_{3}$ seems to generate a new compound consistent with a formulation of ( ${ }^{\text {Ket }}$ guan $)\left(\mathrm{Im}^{\mathrm{Dipp}} \mathrm{N}\right) \mathrm{Ti}(\mathrm{Te})$, but the reaction is slow, very low yielding, and complicated by the competitive formation of $\mathbf{5}$ from the prolonged stirring of $\mathbf{1}$.

Similarly, the addition of excess $\mathrm{Me}_{3} \mathrm{SiN}_{3}$ or 1-azidoadamantane $\left(\mathrm{AdN}_{3}\right)$ to stirring $\mathrm{C}_{6} \mathrm{H}_{6}$ or toluene solutions of 1 result in a rapid color change of the solution from dark brown to red, accompanied by the evolution of $\mathrm{N}_{2}$, to give the $\mathrm{Ti}(\mathrm{IV})$ imido compounds ( ${ }^{\text {Ket }}$ guan $)\left(\mathrm{Im}^{\text {Dipp }} \mathrm{N}\right) \mathrm{Ti}(\mathrm{NR})\left(\mathrm{R}=\mathrm{Me}_{3} \mathrm{Si}\right.$ (17), Ad (18)) (Scheme 1) in $81-88 \%$ yields. On the other hand, treatment of 1 with excess $\mathrm{NaN}_{3}$ failed to provide tractable products, while attempts to desilylate 17 were unsuccessful.

Single crystals of $13 \cdot \mathrm{Et}_{2} \mathrm{O}, 14 \cdot \mathrm{Et}_{2} \mathrm{O}, 15 \cdot \mathrm{Et}_{2} \mathrm{O}, 17 \cdot \mathrm{Et}_{2} \mathrm{O}$, and $18 \cdot \mathrm{Et}_{2} \mathrm{O}$ can be readily grown out of concentrated $\mathrm{Et}_{2} \mathrm{O}$ solutions that have been stored at $-25{ }^{\circ} \mathrm{C}$ for several days, while $16 \cdot \mathrm{C}_{6} \mathrm{H}_{14}$ can be isolated from concentrated hexanes solutions. Despite their similarities, the molecules crystallize 
Scheme 1. Synthesis of Titanium Metal-Ligand Multiple Bonds via Atom Transfer Reactions

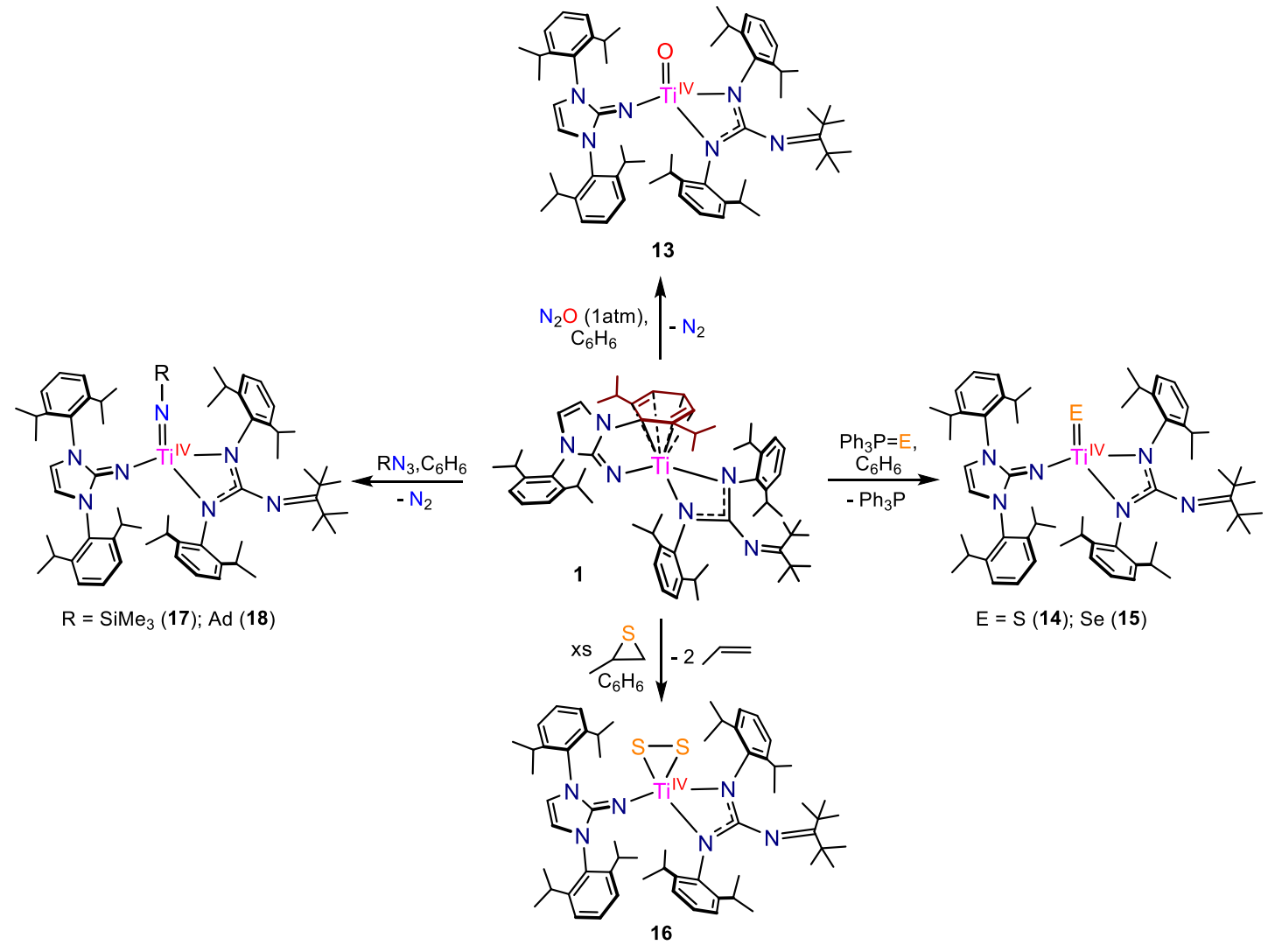

across a number of crystallographic systems in the $P \overline{1}, P 2_{1} / c$, $P 2_{1} / c, P 2_{1} / c, P 2_{1}$, and $P 2_{1} / n$ space groups for $13 \cdot \mathrm{Et}_{2} \mathrm{O}-18$. $\mathrm{Et}_{2} \mathrm{O}$, respectively (Table $\mathrm{S} 1$ ). The compounds are structurally analogous and show the chalcogenide atom or imido ligand sitting in the apical position within a pocket formed by the peripheral Dipp groups. The solid-state molecular structures of 13. $\mathrm{Et}_{2} \mathrm{O}$ and $17 \cdot \mathrm{Et}_{2} \mathrm{O}$ are shown in Figures 9 and 10 as representative examples with the depictions of the other molecular structures contained in the Supporting Information (Figures S64-S68).

Titanium oxo and imido complexes are well-known and the $\mathrm{Ti}=\mathrm{O}$ bond in $13 \cdot \mathrm{Et}_{2} \mathrm{O}(\mathrm{Til}-\mathrm{O} 1=1.641(1) \AA)$ and the $\mathrm{Ti}=$ $\mathrm{NR}$ bonds in $\mathbf{1 7} \cdot \mathrm{Et}_{2} \mathrm{O}(\mathrm{Ti1}-\mathrm{N} 7=1.717(4) \AA)$ and $\mathbf{1 8} \cdot \mathrm{Et}_{2} \mathrm{O}$ (Ti1-N7 = 1.75 (1) $\AA$ ) are well within the normal bond length ranges (cf. $\mathrm{Cp}_{2}^{*} \mathrm{Ti}(\mathrm{O})(\mathrm{py}): \mathrm{Ti}-\mathrm{O}=1.665(3) \AA ; \quad\left(\eta^{5}-\right.$ $\left.\left.\mathrm{C}_{5} \mathrm{H}_{4} \mathrm{SiMe}_{3}\right)_{2} \mathrm{Ti}\left(\mathrm{NSiMe}_{3}\right): \mathrm{Ti}-\mathrm{N}=1.722(4) \AA\right) .{ }^{93,101}$ On the other hand, $14 \cdot \mathrm{Et}_{2} \mathrm{O}$ and $\mathbf{1 5} \cdot \mathrm{Et}_{2} \mathrm{O}$ join the ranks of only a handful of heavier $\mathrm{Ti}=\mathrm{E} \quad\left(\mathrm{E}=\mathrm{S} ;^{100,104-108} \mathrm{Se}^{77,97}\right)$ chalcogenide complexes that have been reported; yet, the titanium-chalcogenide bonds in $\mathbf{1 4} \cdot \mathrm{Et}_{2} \mathrm{O}(\mathrm{Til}-\mathrm{S} 1=2.128(6)$ $\AA)$ and $15 \cdot \mathrm{Et}_{2} \mathrm{O}(\mathrm{Til}-\mathrm{Se} 1=2.258(7) \AA)$ are comparable to known $\mathrm{Ti}=\mathrm{E}$ bond distances (cf. $\left[\mathrm{PhC}\left(\mathrm{NSiMe}_{3}\right)_{2}\right]_{2} \mathrm{Ti}(\mathrm{S})$ (py): $\mathrm{Ti}-\mathrm{S}=2.139(1) \AA ̊$; $\left(\kappa^{3}-\mathrm{Tp}\right)\left(\kappa^{2}-\mathrm{Tp}\right) \mathrm{Ti}(\mathrm{Se}): \mathrm{Ti}-\mathrm{Se}=$ 2.254(1) $\AA) .{ }^{97,100}$ Moreover, titanium-disulfides are relatively rare though well-studied, ${ }^{64,94,97,108-112}$ and the $\mathrm{Ti}-\mathrm{S}$ bonds in 16. $\mathrm{C}_{6} \mathrm{H}_{14}(\mathrm{Ti}-\mathrm{S}=2.32 \AA(\mathrm{avg}))$ are close to those found for $(\mathrm{TpTP}) \mathrm{Ti}\left(\mathrm{S}_{2}\right)(\mathrm{TpTP}=\operatorname{tetrakis}(p$-tolyl $)$ porphyrin $)(\mathrm{Ti}-\mathrm{S}=$ $2.30 \AA$ (avg)).

Furthermore, the metrical parameters of selected structural features in 13. $\mathrm{Et}_{2} \mathrm{O}-\mathbf{1 8} \cdot \mathrm{Et}_{2} \mathrm{O}$ are presented in Table 1 and apparently show a general, inverse trend between the $\mathrm{Ti}=\mathrm{E}$ and $\mathrm{Ti}-\mathrm{N}_{\mathrm{Im}}$ bond lengths. Specifically, as the donor ligand "E"

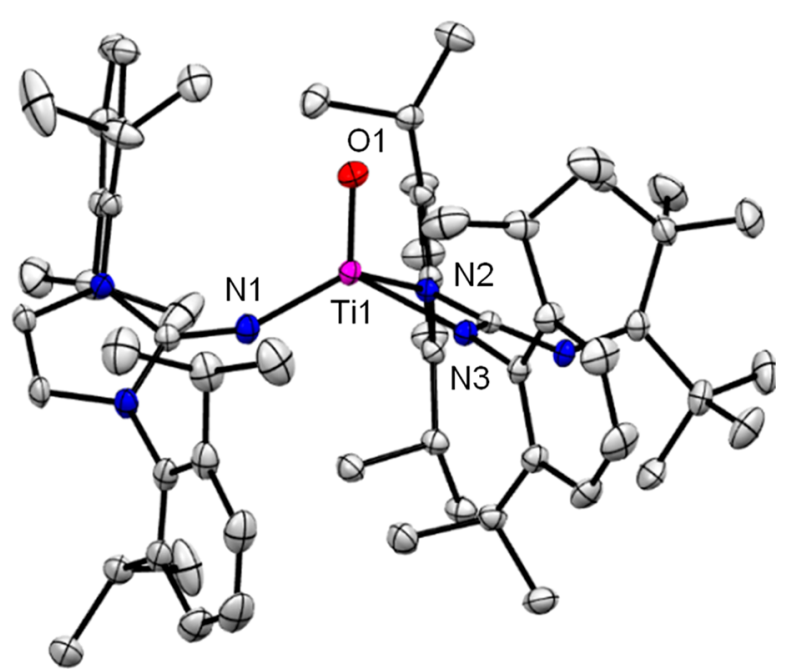

Figure 9. Solid-state molecular structure of $13 \cdot \mathrm{Et}_{2} \mathrm{O}$ with $50 \%$ probability ellipsoids. Hydrogen atoms and cocrystallized solvent omitted for clarity.

becomes progressively softer, the $\mathrm{Ti}-\mathrm{N}_{\mathrm{Im}}$ bond length is seen to decrease. For example, the $\mathrm{Ti}-\mathrm{N}_{\mathrm{Im}}$ distance in $18 \cdot \mathrm{Et}_{2} \mathrm{O}$ ( Ti1-N1 = 1.888(9) $\AA$ ) is significantly longer than that of $\mathbf{1 5}$. $\mathrm{Et}_{2} \mathrm{O}(\mathrm{Ti} 1-\mathrm{N} 1=1.838(3) \AA)$. This pattern suggests that the bond between titanium and the imidazolin-2-iminato ligand is sensitive to the donor strength of the heteroatom " $E$ " (given the minimal steric profile of the chalcogenide atom) with the $\mathrm{Ti}-\mathrm{N}_{\mathrm{Im}}$ bonding interaction seemingly enhancing as " $\mathrm{E}$ "donicity wanes. Thus, the $\mathrm{Ti}-\mathrm{N}_{\mathrm{Im}}$ bond metrics may be useful 


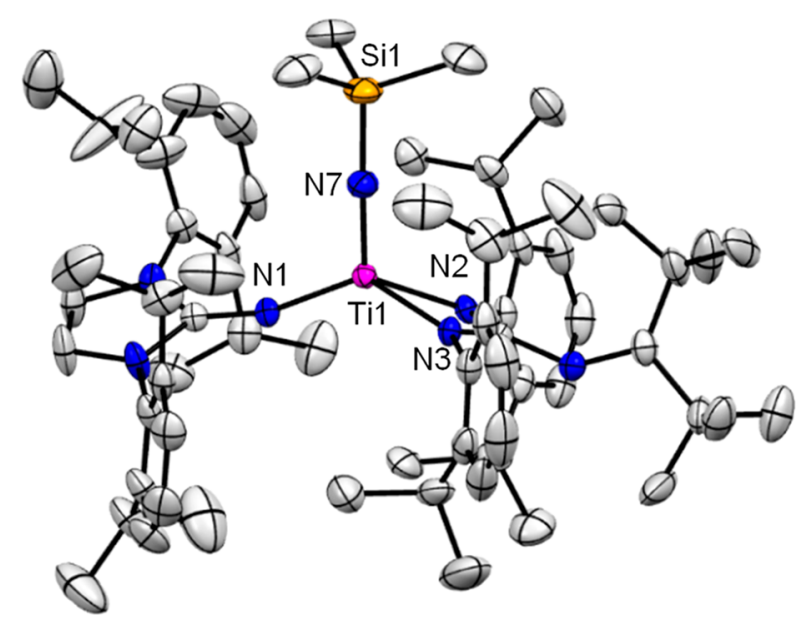

Figure 10. Solid-state molecular structure of $17 \cdot \mathrm{Et}_{2} \mathrm{O}$ with $50 \%$ probability ellipsoids. Hydrogen atoms and cocrystallized $\mathrm{Et}_{2} \mathrm{O}$ omitted for clarity.

Table 1. Select Solid-State Metrical Parameters for ( ${ }^{\text {Ket }}$ guan $)\left(\operatorname{Im}^{\text {Dipp }} \mathbf{N}\right) \mathrm{Ti}(\mathrm{E})$

\begin{tabular}{lllc}
\multicolumn{1}{c}{ compound } & $\mathrm{Ti}=\mathrm{E}(\AA)$ & $\mathrm{Ti}-\mathrm{N}_{\mathrm{Im}}(\AA)$ & $\mathrm{Ti}-\mathrm{N}_{\mathrm{Im}}-\mathrm{C}_{\mathrm{Im}}(\mathrm{deg})$ \\
$\mathbf{1 3} \cdot \mathrm{Et}_{2} \mathrm{O}(\mathrm{E}=\mathrm{O})$ & $1.641(1)$ & $1.871(2)$ & $157.9(2)$ \\
$\mathbf{1 4} \cdot \mathrm{Et}_{2} \mathrm{O}(\mathrm{E}=\mathrm{S})$ & $2.128(6)$ & $1.843(2)$ & $152.8(1)$ \\
$\mathbf{1 5} \cdot \mathrm{Et}_{2} \mathrm{O}(\mathrm{E}=\mathrm{Se})$ & $2.258(7)$ & $1.838(3)$ & $154.1(2)$ \\
$\mathbf{1 6} \cdot \mathrm{C}_{6} \mathrm{H}_{14}\left(\mathrm{E}=\mathrm{S}_{2}\right)$ & - & $1.832(\mathrm{avg})$ & $146.6(\mathrm{avg})$ \\
$\mathbf{1 7} \cdot \mathrm{Et}_{2} \mathrm{O}\left(\mathrm{E}=\mathrm{NSiMe}_{3}\right)$ & $1.717(4)$ & $1.878(3)$ & $162.6(3)$ \\
$\mathbf{1 8} \cdot \mathrm{Et}_{2} \mathrm{O}(\mathrm{E}=\mathrm{NAd})$ & $1.75(1)$ & $1.888(9)$ & $163.3(6)$ \\
\hline
\end{tabular}

as a relative measure for the degree of the $\mathrm{Ti}=\mathrm{E}$ bond interaction in our system.

The ${ }^{1} \mathrm{H}$ NMR spectra of $\mathbf{1 3 - 1 8}$ in $\mathrm{C}_{6} \mathrm{D}_{6}$ are qualitatively identical (see SI) and show a resonance pattern consistent with $C_{s}$ symmetry in solution where the $\mathrm{Ti}-\mathrm{N}_{\mathrm{Im}}$ bond does not appear rotationally restricted on the NMR time scale, leading to one isopropyl methine and one olefinic proton signal attributable to the imidazolin-2-iminato group in a 4:2 ratio, respectively. Interestingly, the resonance peaks of the methine protons of the Ket guan- ligand in closest proximity to the "E"group are a spectral hallmark of these compounds. These protons are highly deshielded, appearing from $4.69 \mathrm{ppm}$ in $\mathbf{1 3}$. $\mathrm{Et}_{2} \mathrm{O}$ to $5.97 \mathrm{ppm}$ in $15 \cdot \mathrm{Et}_{2} \mathrm{O}$, though there seems to be no obvious correlation between the relative electronegativity of the chalcogenide or imido groups and the chemical shift values of the methine protons.

A similar spectral feature has been observed in the $\mathrm{Ti}(\mathrm{IV})$ imido [HC(NDipp $\left.)_{2}\right]_{2} \mathrm{Ti}(\mathrm{Ntolyl})$, which displays two distinct methine resonances in its ${ }^{1} \mathrm{H}$ NMR spectrum with one set appearing more deshielded at $4.58 \mathrm{ppm},{ }^{113}$ which is near the corresponding peak value of $4.73 \mathrm{ppm}$ found for 17 and 18 . This deshielding effect appears to be a solution-phase phenomenon, as the distance of the $\mathrm{Ti}=\mathrm{E}-\mathrm{H}$ bonds of the calculated proton positions in the solid-state structures of $\mathbf{1 3}$. $\mathrm{Et}_{2} \mathrm{O}-18 \cdot \mathrm{Et}_{2} \mathrm{O}$ are unexceptional (e.g., $\mathrm{Se} 1-\mathrm{H} 38=2.987 \AA$ in 15. $\left.\mathrm{Et}_{2} \mathrm{O}\right)$.

\section{SUMMARY}

We recently reported the synthesis of the intramolecularly arene-masked titanium complex $\left({ }^{\mathrm{Ket}}\right.$ guan $)\left(\eta^{6}-\mathrm{Im}^{\mathrm{Dipp}} \mathrm{N}\right) \mathrm{Ti}(\mathbf{1})$, which is best formulated as a $\mathrm{Ti}(\mathrm{IV})$ compound coordinated to a redox noninnocent 1,4-cyclohexadiene dianion formed by reduction of a peripheral imidazolin-2-iminato Dipp group. ${ }^{51}$ In this canonical form, the metal center can be formally described as high-valent, $d^{0}$ titanium. Nonetheless, we have previously shown that $\mathbf{1}$ behaves as a potent two-electron reductant that can reductively activate $\mathrm{C}-\mathrm{H}$ bonds. This reactivity suggests that $\mathbf{1}$ may be best treated as a $\mathrm{Ti}(\mathrm{II})$ synthon. Accordingly, we have performed an exhaustive examination of the redox chemistry of $\mathbf{1}$. Through its reactivity with substrates such as benzophenone or pyridine, to give the $\mathrm{Ti}(\mathrm{III})$ complexes ( ${ }^{\text {Ket }}$ guan $)\left(\mathrm{Im}^{\text {Dipp }} \mathrm{N}\right) \mathrm{Ti}\left(\eta^{1}-\mathrm{OCPh}_{2}\right)(\mathbf{6})$ and $\left[\left({ }^{\text {Ket }} \text { guan }\right)\left(\mathrm{Im}^{\text {Dipp }} \mathrm{N}\right) \mathrm{Ti}\right]_{2}\left[\mu^{2}-\left(\mathrm{NC}_{5} \mathrm{H}_{5}-\mathrm{H}_{5} \mathrm{C}_{5} \mathrm{~N}\right)\right](7)$, the oneelectron reduction of these substrates approximately bookends the " $\mathrm{Ti}(\mathrm{II}) /(\mathrm{III})$ " redox potential of $\mathbf{1}$ between -2.3 to $-3.1 \mathrm{~V}$ (vs $\left[\mathrm{Cp}_{2} \mathrm{Fe}\right]^{0 /+}$ ). In line with this, $\mathrm{Na} / \mathrm{Hg}$ amalgam is insufficient to reduce ( ${ }^{\text {Ket }}$ guan $)\left(\operatorname{Im}^{\text {Dipp }} \mathrm{N}\right) \mathrm{TiCl}_{2}\left(2^{\mathrm{Cl}}\right)$ to $\mathbf{1}$ but instead gives ( ${ }^{\text {Ket }}$ guan $)\left(\mathrm{Im}^{\text {Dipp }} \mathrm{N}\right) \mathrm{TiCl}(3)$. Notably, treatment of 1 with $\pi$-acids leads to a host of products from the bona fide $\mathrm{Ti}(\mathrm{II})$ dicarbonyl ( ${ }^{\text {Ket }}$ guan $)\left(\mathrm{Im}^{\mathrm{Dipp}} \mathrm{N}\right) \mathrm{Ti}(\mathrm{CO})_{2}(\mathbf{8})^{51}$ to the $\mathrm{Ti}(\mathrm{III})$ and $\mathrm{Ti}(\mathrm{IV})$ complexes (Ket ${ }_{\text {guan }}\left(\mathrm{Im}^{\mathrm{Dipp}} \mathrm{N}\right) \mathrm{Ti}(\mathrm{CN})$ (CNCy) (9) and (Im $\left.{ }^{\text {Dipp }} \mathrm{N}\right)\left[(\mathrm{DippN})\left(2{ }^{i} \mathrm{PrC}_{6} \mathrm{H}_{3}-6-\left(\eta^{1}-\right.\right.\right.$ $\left.\left.\left.\mathrm{CH}_{3} \mathrm{CHCH}_{2}\right) \mathrm{N}\right) \mathrm{C}\left(\mathrm{NC}^{t} \mathrm{Bu}_{2}\right)\right] \mathrm{Ti}\left[\mathrm{NC}(\mathrm{H})^{t} \mathrm{Bu}\right]$ (10), with the latter two products forming as a consequence of the oneelectron reduction of the $\pi$-acid. The propensity of 1 to effect two-electron chemistry was surveyed through its reactivity with $\mathrm{N}_{2} \mathrm{O}$, chalcogen transfer reagents, and organoazides to generate the $\mathrm{Ti}(\mathrm{IV})$ complexes ( ${ }^{\mathrm{Ket}}$ guan $)\left(\mathrm{Im}^{\mathrm{Dipp}} \mathrm{N}\right) \mathrm{Ti}(\mathrm{E})$ (E $=\mathrm{O}$ (13), S (14), Se (15), $\mathrm{S}_{2}$ (16), $\mathrm{Me}_{3} \mathrm{SiN}$ (17), AdN (18)). The synthesis of 13-18 further corroborates the $\mathrm{Ti}(\mathrm{II})$ character of $\mathbf{1}$ and unequivocally shows that the [( ${ }^{\text {Ket }}$ guan)$\left.\left(\mathrm{Im}^{\mathrm{Dipp}} \mathrm{N}\right) \mathrm{Ti}\right]^{n+}$ manifold can readily accommodate titanium metal-ligand multiple bonds. In summary, the redox chemistry of $\mathbf{1}$ in its capacity as a $\mathrm{Ti}(\mathrm{II})$ synthon clearly shows the chemical variety of low-valent early metals (LVEMs) and their ability to reductively activate a host of substrates. We are continuing to study the chemistry of $\mathbf{1}$ and its less sterically encumbering analogues for the unique activation of other small molecules.

\section{EXPERIMENTAL SECTION}

General Considerations. All air and moisture-sensitive operations were performed in a MBraun drybox under an atmosphere of purified nitrogen or using high vacuum standard Schlenk techniques. Benzene, $\mathrm{Et}_{2} \mathrm{O}$, hexanes, pentane, toluene, and THF were dried using a Pure Process Technology Solvent Purification System and subsequently stored under a dinitrogen atmosphere over activated 4 $\AA$ molecular sieves. All deuterated solvents were purchased from Cambridge Isotope Laboratories Inc. The deuterated solvents, 1,2difluorobenzene, and pivalonitrile were degassed by three freezepump-thaw cycles and were dried over activated $4 \AA$ molecular sieves for $24 \mathrm{~h}$ prior to use. The Celite and the $4 \AA$ molecular sieves were heated to $150{ }^{\circ} \mathrm{C}$ for at least $24 \mathrm{~h}$ and then cooled under vacuum. Anhydrous LiOTf was purchased from Strem Chemicals, Inc. All other reagents were purchased from commercial sources and used as received. NMR spectra were recorded on a Bruker AVANCE III 400 $\mathrm{MHz}$ spectrometer. Resonance assignments in the ${ }^{13} \mathrm{C}\left\{{ }^{1} \mathrm{H}\right\}$ NMR spectra were based upon ${ }^{1} \mathrm{H}-{ }^{13} \mathrm{C}$ HSQC $2 \mathrm{D}$ correlation spectra. ${ }^{1} \mathrm{H}$ $\mathrm{NMR}$ and ${ }^{13} \mathrm{C}$ NMR spectra are referenced to the residual ${ }^{1} \mathrm{H}$ solvent peaks as internal standards or the characteristic ${ }^{13} \mathrm{C}$ resonances of the solvent. ${ }^{19} \mathrm{~F}\left\{{ }^{1} \mathrm{H}\right\}$ spectra were referenced to external $\alpha, \alpha, \alpha$ trifluorotoluene $\left(-63.72 \mathrm{ppm}\right.$ relative to $\mathrm{CFCl}_{3}$ at $\left.0 \mathrm{ppm}\right)$. IR data were collected using a Thermo Scientific Nicolet iS5 spectrometer. UV-vis spectra were recorded on a Zhengzhou Nanbei Instrument spectrophotometer. EPR measurements were performed on a Bruker EMX Plus X-band spectrometer. Elemental Analyses were performed by Midwest Microlabs, LLC. 
Synthesis of (Ket guan)(Im $\left.{ }^{\text {Dipp }} \mathrm{N}\right) \mathrm{TiCl}$ (3). A $20 \mathrm{~mL}$ scintillation vial was loaded with metallic sodium $(0.009 \mathrm{~g}, 0.390 \mathrm{mmol})$, elemental mercury $(0.179 \mathrm{~g})$, toluene $(5 \mathrm{~mL})$, and $2^{\mathrm{Cl}}(0.100 \mathrm{~g}, 0.098 \mathrm{mmol})$, forming an orange slurry, which was vigorously stirred. Over the course of 3 days, a gradual color change to green was observed, accompanied by precipitation of a fine gray solid. The mixture was filtered through a Celite column $(2 \mathrm{~cm} \times 0.5 \mathrm{~cm})$ supported on glass wool to give a dark green filtrate. All volatiles were removed via reduced pressure until a pale green solid was obtained. The material was crystallized using a solution of $\mathrm{Et}_{2} \mathrm{O}(2 \mathrm{~mL})$ followed by storage at $-25{ }^{\circ} \mathrm{C}$, giving amber crystals after 2 days. The supernatant was decanted and the crystals dried under reduced pressure to afford a pale green solid. Yield: $0.087 \mathrm{~g}, 89 \% .{ }^{1} \mathrm{H}$ NMR $\left(25{ }^{\circ} \mathrm{C}, 400 \mathrm{MHz}\right.$, $\left.\mathrm{C}_{6} \mathrm{D}_{6}\right) \delta 0.3$ (br s), 0.88 (br s), 1.46 (br s), 6.14 (br s), 6.69 (br s), 8.82 (br s). UV-vis-NIR (toluene, $0.210 \mathrm{mM}, 25^{\circ} \mathrm{C}, \mathrm{L} \cdot \mathrm{mol}^{-1} \cdot \mathrm{cm}^{-1}$ ) $320(\varepsilon=1011)$. Anal. Calcd for $\mathrm{C}_{61} \mathrm{H}_{88} \mathrm{ClN}_{6} \mathrm{Ti}^{2} \mathrm{Et}_{2} \mathrm{O}: \mathrm{C}, 73.44 ; \mathrm{H}$, 9.31; N, 7.90. Found: C, 72.98; H, 9.29; N, 8.14.

Synthesis of $\left(\operatorname{Im}^{\text {Dipp }} N\right)(\operatorname{DippN})\left[\eta^{2}-\left({ }^{(} B u_{2} C\right) N C(N D i p p)\right](T H F) T i$ (4). A $20 \mathrm{~mL}$ scintillation vial was loaded with $2^{\mathrm{Cl}}(0.200 \mathrm{~g}, 0.194 \mathrm{mmol})$, $\mathrm{KC}_{8}(0.078 \mathrm{~g}, 0.582 \mathrm{mmol})$, and THF $(10 \mathrm{~mL})$, forming a darkbrown slurry, which was vigorously stirred. After $12 \mathrm{~h}$, a black precipitate formed. All volatiles were removed via reduced pressure until a very dark solid was obtained. The solid was triturated with hexanes $(10 \mathrm{~mL})$, and the solution filtered through a Celite column $(2$ $\mathrm{cm} \times 0.5 \mathrm{~cm}$ ) supported on glass wool to give a light cherry filtrate plus a black plug (graphite). All volatiles were removed via reduced pressure until a pale orange solid was obtained. The material was crystallized using a solution of THF $(2 \mathrm{~mL})$ layered with hexanes $(2$ $\mathrm{mL}$ ) followed by storage at $-25^{\circ} \mathrm{C}$, giving light orange crystals after 7 days. Yield: $0.125 \mathrm{~g}, 62 \% .{ }^{1} \mathrm{H}$ NMR $\left(25^{\circ} \mathrm{C}, 400 \mathrm{MHz}, \mathrm{C}_{6} \mathrm{D}_{6}\right) \delta 0.85$ $\left(\mathrm{m}, 4 \mathrm{H}, J_{\mathrm{HH}}=7 \mathrm{~Hz}\right), 0.92\left(\mathrm{~d}, 2 \mathrm{H}, J_{\mathrm{HH}}=7 \mathrm{~Hz}\right), 0.95\left(\mathrm{~d}, 3 \mathrm{H}, J_{\mathrm{HH}}=7\right.$ $\mathrm{Hz}), 1.09$ (br s, $\left.18 \mathrm{H}, \mathrm{Me}_{3} \mathrm{C}\right), 1.20\left(\mathrm{~m}, 22 \mathrm{H}, \mathrm{Me}_{2} \mathrm{CH}\right) 1.29(\mathrm{~m}, 16 \mathrm{H}$, $\left.\mathrm{Me}_{2} \mathrm{CH}\right), 1.46\left(\mathrm{~d}, 6 \mathrm{H}, J_{\mathrm{HH}}=7 \mathrm{~Hz}, \mathrm{Me}_{2} \mathrm{CH}\right), 2.94(\mathrm{br} \mathrm{s}, 1 \mathrm{H}), 3.23(\mathrm{br}$ s, $2 \mathrm{H}$ ), 3.42 (sept, $2 \mathrm{H}, J_{\mathrm{HH}}=7 \mathrm{~Hz}, \mathrm{Me}_{2} \mathrm{CH}$ ), 3.49 (sept, $2 \mathrm{H}, J_{\mathrm{HH}}=7$ $\mathrm{Hz}, \mathrm{Me}_{2} \mathrm{CH}$ ), 3.62 (br s, $2 \mathrm{H}$ ) 3.71 (br s, $\left.1 \mathrm{H}\right), 3.94$ (sept, $2 \mathrm{H}, J_{\mathrm{HH}}=7$ $\left.\mathrm{Hz}, \mathrm{Me}_{2} \mathrm{CH}\right), 5.90$ (s, 2H, ImidNH), 6.86-7.16 (12H, aryl protons). (Note: Trace but persistent impurities prevented satisfactory combustion analyses.)

Synthesis of (Ket guan)(Im $\left.{ }^{\text {Dipp }} N\right) T i\left(\eta^{1}-O C P h_{2}\right)$ (6). A $20 \mathrm{~mL}$ scintillation vial was loaded with $1(0.100 \mathrm{~g}, 0.104 \mathrm{mmol})$ and benzene $(3 \mathrm{~mL})$, forming a dark-brown solution. To the stirring solution, benzophenone $(0.019 \mathrm{~g}, 0.104 \mathrm{mmol})$ was added in one portion, resulting in the formation of a vibrant purple color. At this stage, the vial was allowed to stand at $25{ }^{\circ} \mathrm{C}$ for $24 \mathrm{~h}$ without stirring, which resulted in the deposition of dark red crystals. The supernatant was decanted, and the crystals washed with cold pentanes $(5 \mathrm{~mL},-25$ ${ }^{\circ} \mathrm{C}$ ) and dried under reduced pressure to afford a dark solid. Compound 6 can be recrystallized from a 10 to 1 pentanes to toluene mixture. Yield: $0.097 \mathrm{mg}, 81 \% .{ }^{1} \mathrm{H}$ NMR $\left(25{ }^{\circ} \mathrm{C}, 400 \mathrm{MHz}, \mathrm{C}_{6} \mathrm{D}_{6}\right) \delta$ -0.13 (br s, $6 \mathrm{H}, \mathrm{Me}_{2} \mathrm{CH}$ ), -0.01 (br s, $6 \mathrm{H}, \mathrm{Me}_{2} \mathrm{CH}$ ), 0.93 (s, $12 \mathrm{H}$, $\mathrm{Me}_{2} \mathrm{CH}$ ), 1.00 (s, $8 \mathrm{H}$, aryl), $1.22\left(\mathrm{~s}, 12 \mathrm{H}, \mathrm{Me}_{2} \mathrm{CH}\right), 1.44$ (s, $18 \mathrm{H}$, $\mathrm{Me}_{3} \mathrm{C}$ ), 1.88 (s, 4H, $\mathrm{Me}_{2} \mathrm{CH}$ ), 2.04 (s, 6H, Me $2 \mathrm{CH}$ ), 2.57 (s, 6H, $\mathrm{Me}_{2} \mathrm{CH}$ ), 3.51 (s, $\left.4 \mathrm{H}, \mathrm{Me}_{2} \mathrm{CH}\right), 3.75$ (s, $2 \mathrm{H}$, aryl), 4.21 (s, $2 \mathrm{H}$, ImidH), 6.50 (s, $2 \mathrm{H}$, aryl), $6.74(\mathrm{~s}, 4 \mathrm{H}$, aryl), 7.02 (s, 4H, aryl), 7.69 (s, $2 \mathrm{H}$, aryl). UV-vis-NIR (toluene, $0.070 \mathrm{mM}, 25^{\circ} \mathrm{C}, \mathrm{L} \cdot \mathrm{mol}^{-1}$. $\left.\mathrm{cm}^{-1}\right) 326(\varepsilon=10400), 442(\varepsilon=1312), 512(\varepsilon=1960), 564(\varepsilon=$ 2220), $688(\varepsilon=780), 1113(\varepsilon=86)$. IR (KBr Pellet, $\left.\mathrm{cm}^{-1}\right) 415(\mathrm{w})$, $569(\mathrm{w}), 606(\mathrm{w}), 627(\mathrm{w}), 639(\mathrm{w}), 703(\mathrm{~m}), 753(\mathrm{w}), 793(\mathrm{w}), 807$ $(\mathrm{w}), 842(\mathrm{w}), 901(\mathrm{w}), 922(\mathrm{w}), 940(\mathrm{w}), 905(\mathrm{w}), 921(\mathrm{w}), 940(\mathrm{w})$, $975(\mathrm{w}), 1016(\mathrm{w}), 1051(\mathrm{w}), 1106(\mathrm{w}), 1179(\mathrm{w}), 1215(\mathrm{w}), 1273$ (m), $1328(\mathrm{~m}), 1364(\mathrm{~m}), 1407(\mathrm{~m}), 1546(\mathrm{~s}), 1578(\mathrm{~m}), 1597(\mathrm{~m})$, $1664(\mathrm{~m}), 1678(\mathrm{~m}), 2345(\mathrm{w}), 2364(\mathrm{w}), 2870(\mathrm{~m}), 2930(\mathrm{~s}), 2963$ (s), $3058(w), 3411(w)$. Anal. Calcd for $\mathrm{C}_{74} \mathrm{H}_{98} \mathrm{~N}_{6} \mathrm{OTi} \cdot \mathrm{C}_{5} \mathrm{H}_{12}$ : C, 78.55; H, 9.19; N, 6.95. Found: C, 78.81; H, 9.09; N, 6.52.

Synthesis of [( ${ }^{\text {Ket }}$ guan) $\left.\left(\mathrm{Im}^{\text {Dipp }} \mathrm{N}\right) \mathrm{Ti}\right]_{2}\left[\mu^{2}-\left(\mathrm{NC}_{5} \mathrm{H}_{5}-\mathrm{H}_{5} \mathrm{C}_{5} \mathrm{~N}\right)\right]$ (7). A 20 $\mathrm{mL}$ scintillation vial was loaded with $1(0.100 \mathrm{~g}, 0.104 \mathrm{mmol})$ and cold THF $\left(3 \mathrm{~mL},-25^{\circ} \mathrm{C}\right)$, forming a dark-brown solution. To this solution, pyridine $(0.026 \mathrm{~g}, 0.025 \mathrm{~mL}, 0.312 \mathrm{mmol})$ was added via a micropipette resulting in an instantaneous color change to deeppurple. The deep-purple color gradually turned dark-brown within 5 min of stirring and the formation of a green precipitate was observed. The supernatant was decanted, and the green precipitate was washed with hexanes $(5 \mathrm{~mL})$ and dried under dynamic vacuum to afford a green solid. Yield: $0.055 \mathrm{~g}, 53 \%$. UV-vis-NIR (toluene, $0.070 \mathrm{mM}$, $\left.25^{\circ} \mathrm{C}, \mathrm{L} \cdot \mathrm{mol}^{-1} \cdot \mathrm{cm}^{-1}\right) 355(\varepsilon=25470), 380(\varepsilon=25040), 715(\varepsilon=$ 1598), $880(\varepsilon=754)$. Anal. Calcd for $\mathrm{C}_{132} \mathrm{H}_{186} \mathrm{~N}_{14} \mathrm{Ti}$ : C, 76.76; $\mathrm{H}$, 9.09; N, 9.49. Found: C, 72.26; H, 8.83; N, 9.31. (Note: Combustion analysis tested low in carbon content possibly due to poor combustion properties.)

Synthesis of (Ket guan)(Im ${ }^{\text {Dipp } N) T i(C N)(C N C y)}$ (9). To a thawing solution of $1(0.100 \mathrm{~g}, 0.104 \mathrm{mmol})$ in benzene $(5 \mathrm{~mL})$ was added cyclohexyl isocyanide $(0.028 \mathrm{~g}, 0.028 \mathrm{~mL}, 0.220 \mathrm{mmol})$ via a micropipette. A gradual change to a darker brown color was observed upon stirring. After $5 \mathrm{~min}$, all volatiles were removed via reduced pressure until a dark brown solid was obtained. The material was dissolved in $\mathrm{Et}_{2} \mathrm{O}(2 \mathrm{~mL})$ and stored at $-25^{\circ} \mathrm{C}$, giving yellow crystals after 2 days. Yield: $0.075 \mathrm{~g}, 66 \% .{ }^{1} \mathrm{H}$ NMR $\left(25^{\circ} \mathrm{C}, 400 \mathrm{MHz}, \mathrm{C}_{6} \mathrm{D}_{6}\right) \delta$ $0.79,1.23,1.67,6.86$. UV-vis-NIR (toluene, $0.171 \mathrm{mM}, 25{ }^{\circ} \mathrm{C}, \mathrm{L}$. $\left.\mathrm{mol}^{-1} \cdot \mathrm{cm}^{-1}\right) 320(\varepsilon=8640), 380(\varepsilon=3438)$. IR (KBr Pellet, $\left.\mathrm{cm}^{-1}\right)$ $439(\mathrm{w}), 652(\mathrm{~m}), 716(\mathrm{~m}), 752(\mathrm{~s}), 769(\mathrm{~s}), 789(\mathrm{~s}), 808(\mathrm{~s}), 915$ (m), $934(\mathrm{~m}), 975(\mathrm{w}), 1032(\mathrm{~m}), 1059(\mathrm{~m}), 1108(\mathrm{~m}), 1180(\mathrm{~m})$, $1226(\mathrm{w}) 1256(\mathrm{~m}), 1331(\mathrm{~m}), 1363(\mathrm{~m}), 1474(\mathrm{~s}), 1585(\mathrm{~m}) 1633$ $(\mathrm{s}), 1655(\mathrm{~s}), 2138\left(\mathrm{w}, \nu_{\mathrm{C} \equiv \mathrm{N}}\right), 2207\left(\mathrm{w}, \nu_{\mathrm{C} \equiv \mathrm{NCy}}\right), 2869(\mathrm{~s}), 2962(\mathrm{~s})$, $3067(\mathrm{w}), 3136(\mathrm{w}), 3324(\mathrm{w}), 3407(\mathrm{w}), 3430(\mathrm{w})$. Anal. Calcd for $\mathrm{C}_{69} \mathrm{H}_{99} \mathrm{~N}_{8} \mathrm{Ti} \cdot \mathrm{Et}_{2} \mathrm{O}: \mathrm{C}, 75.40 ; \mathrm{H}, 9.46 ; \mathrm{N}, 9.63$. Found: C, 71.74; $\mathrm{H}$, 8.97; N, 9.22. (Note: Combustion analysis tested low in carbon content possibly due to poor combustion properties.)

Synthesis of $\left(\operatorname{Im}^{\text {Dipp }} \mathrm{N}\right)\left[(\operatorname{DippN})\left(2^{-}{ }^{i} \mathrm{PrC}{ }_{6} \mathrm{H}_{3}-6-\left(\eta^{1}-\mathrm{CH}_{3} \mathrm{CHCH}_{2}\right) \mathrm{N}\right) \mathrm{C}\right.$ $\left.\left(N C^{t} B u_{2}\right)\right] T i\left[N C(H)^{t} B u\right](10)$. To a thawing solution of $1(0.100 \mathrm{~g}$, $0.104 \mathrm{mmol})$ in benzene $(5 \mathrm{~mL})$ was added pivalonitrile $(0.018 \mathrm{~g}$, $0.025 \mathrm{~mL}, 0.220 \mathrm{mmol}$ ) via a micropipette. A gradual change to a darker brown color was observed upon stirring. After $12 \mathrm{~h}$, all volatiles were removed via reduced pressure until a red solid was obtained. The material was dissolved in $\mathrm{Et}_{2} \mathrm{O}(2 \mathrm{~mL})$ followed by storage at $-25^{\circ} \mathrm{C}$, giving yellow crystals after 2 days. Yield: $0.071 \mathrm{~g}, 63 \% .{ }^{1} \mathrm{H}$ NMR $(25$ $\left.{ }^{\circ} \mathrm{C}, 400 \mathrm{MHz}, \mathrm{C}_{6} \mathrm{D}_{6}\right) \delta 0.34\left(\mathrm{~m}, 2 \mathrm{H}, \mathrm{CH}_{2}-\mathrm{Ti}\right), 0.47\left(\mathrm{~d}, 3 \mathrm{H}, J_{\mathrm{HH}}=7\right.$ $\left.\mathrm{Hz}, \mathrm{Me}_{2} \mathrm{CH}\right), 0.77\left(\mathrm{~d}, 12 \mathrm{H}, J_{\mathrm{HH}}=7 \mathrm{~Hz}, \mathrm{Me}_{2} \mathrm{CH}\right), 0.83\left(\mathrm{~s}, 9 \mathrm{H}, M e_{3} \mathrm{C}\right)$, $0.92\left(\mathrm{~s}, 9 \mathrm{H}, \mathrm{Me}_{3} \mathrm{C}\right), 1.13$ (d, 6H, $\left.J_{\mathrm{HH}}=7 \mathrm{~Hz}, \mathrm{Me}_{2} \mathrm{CH}\right), 1.17$ (d, 6H, $J_{\mathrm{HH}}=7 \mathrm{~Hz}, \mathrm{Me}_{2} \mathrm{CH}, 1.39\left(\mathrm{~d}, 3 \mathrm{H}, J_{\mathrm{HH}}=7 \mathrm{~Hz}, \mathrm{Me}_{2} \mathrm{CH}\right), 1.43(\mathrm{~m}, 6 \mathrm{H}$, $J_{\mathrm{HH}}=7 \mathrm{~Hz}$, two overlapping $\left.\mathrm{Me}_{2} \mathrm{CH}\right), 1.52(\mathrm{~m}, 9 \mathrm{H}$, two overlapping $M e_{2} \mathrm{CH}$ ), 2.93 (sept, $2 \mathrm{H}, J_{\mathrm{HH}}=7 \mathrm{~Hz}, \mathrm{Me}_{2} \mathrm{CH}$ ), 3.00 (sept, $1 \mathrm{H}, J_{\mathrm{HH}}=$ $\left.7 \mathrm{~Hz}, \mathrm{Me}_{2} \mathrm{CH}\right), 3.39\left(\mathrm{~m}, 1 \mathrm{H}, \mathrm{Me}_{2} \mathrm{CHCH}_{2}\right), 3.50(\mathrm{~m}, 3 \mathrm{H}$, two overlapping $\mathrm{Me}_{2} \mathrm{CH}$ ), 4.08 (sept, $\left.1 \mathrm{H}, J_{\mathrm{HH}}=7 \mathrm{~Hz}, \mathrm{Me}_{2} \mathrm{CH}\right), 5.78$ (s, $2 \mathrm{H}$, Imid $H), 7.03-7.26(\operatorname{aryl}, 12 \mathrm{H}), 8.32\left(\mathrm{~s}, 1 \mathrm{H},\left(\mathrm{Me}_{3} \mathrm{C}\right) \mathrm{CH}=\mathrm{N}\right)$.). ${ }^{13} \mathrm{C}\left\{{ }^{1} \mathrm{H}\right\}$ NMR $\left(25{ }^{\circ} \mathrm{C}, 101 \mathrm{MHz}, \mathrm{C}_{6} \mathrm{D}_{6}\right) \delta, 23.07\left(\mathrm{Me}_{2} \mathrm{CH}\right), 23.78$ $\left(\mathrm{Me}_{2} \mathrm{CH}\right), 23.97\left(\mathrm{Me}_{2} \mathrm{CH}\right), 24.05\left(\mathrm{Me}_{2} \mathrm{CH}\right), 24.22\left(\mathrm{Me}_{2} \mathrm{CH}\right), 24.28$ $\left(\mathrm{Me}_{2} \mathrm{CH}\right), 24.44\left(\mathrm{Me}_{2} \mathrm{CH}\right), 24.83\left(\mathrm{Me}_{3} \mathrm{C}\right), 25.23\left(\mathrm{Me}_{2} \mathrm{CH}\right), 26.39$, $26.63\left(\mathrm{Me}_{2} \mathrm{CH}\right), 26.72\left(\mathrm{Me}_{3} \mathrm{C}\right), 27.19\left(\mathrm{Me} e_{2} \mathrm{CH}\right), 28.01\left(\mathrm{Me}_{2} \mathrm{CH}\right)$, $28.39\left(\mathrm{Me}_{2} \mathrm{CH}\right), 28.85\left(\mathrm{Me}_{3} \mathrm{C}\right), 29.59\left(\mathrm{Me}_{2} \mathrm{CH}\right), 29.69\left(\mathrm{Me}_{2} \mathrm{CH}\right)$, $36.56\left(\mathrm{Me}_{2} \mathrm{CHCH}_{2}\right), 40.54,43.43,43.91,68.03\left(\mathrm{CH}_{2}-\mathrm{Ti}\right), 114.78$ (Imid $C=C$ ), 122.08 (aryl), 122.91 (aryl), 123.16 (aryl), 123.52 (aryl), 123.74, 123.95, 124.45 (aryl), 124.7, 129.66 (aryl), 135.24, 138.64, 142.63, 143.1, 143.55, 145.89, 146.44, 147.24, 147.71, 147.78, 160.26, $172.82\left({ }^{t} \mathrm{Bu}_{2} \mathrm{C}=\mathrm{N}\right), 177.05\left(\mathrm{CN}_{3}\right) . \mathrm{UV}-\mathrm{vis}-\mathrm{NIR}$ (toluene, $\left.0.132 \mathrm{mM}, 25{ }^{\circ} \mathrm{C}, \mathrm{L} \cdot \mathrm{mol}^{-1} \cdot \mathrm{cm}^{-1}\right) 375(\varepsilon=5855)$. IR (KBr Pellet, $\left.\mathrm{cm}^{-1}\right) 507(\mathrm{w}), 543(\mathrm{w}), 610(\mathrm{w}), 674(\mathrm{w}), 714(\mathrm{w}), 752(\mathrm{~m}), 794$ (m), $899(\mathrm{~m}) 921(\mathrm{~m}), 923(\mathrm{~m}), 972(\mathrm{~m}), 1050(\mathrm{~m}), 1109(\mathrm{w}), 1180$ (w), $1211(\mathrm{~m}), 1325(\mathrm{~s}), 1364(\mathrm{~s}), 1390(\mathrm{~s}), 1432(\mathrm{~s}), 1465(\mathrm{~s}), 1558$ (s), 1597(s), $1676(\mathrm{~m}), 2048(\mathrm{~s}), 2133(\mathrm{~m}), 2868(\mathrm{~s}), 2966(\mathrm{~s}), 3063$ (w). Anal. Calcd for $\mathrm{C}_{66} \mathrm{H}_{97} \mathrm{~N}_{7} \mathrm{Ti}^{2} \cdot 3 \mathrm{Et}_{2} \mathrm{O}: \mathrm{C}, 74.40 ; \mathrm{H}, 10.18 ; \mathrm{N}, 7.79$. Found: C, 73.88; H, 9.66; N, 7.93.

Synthesis of $\left(\operatorname{Im}^{\text {Dipp }} \mathrm{N}\right)\left[(\mathrm{DippN})\left(2^{i}{ }^{i} \mathrm{PrC}{ }_{6} \mathrm{H}_{3}-6-\left(\eta^{1}-\mathrm{CH}_{3} \mathrm{CHCH}_{2}\right) \mathrm{N}\right) \mathrm{C}\right.$ $\left.\left(\mathrm{NC}^{t} \mathrm{Bu}_{2}\right)\right] \mathrm{Ti}\left(\mathrm{OCPh}{ }_{2} \mathrm{H}\right)(11)$. A $50 \mathrm{~mL}$ round-bottom Cajon flask was loaded with $6(0.120 \mathrm{~g}, 0.106 \mathrm{mmol})$ and benzene $(10 \mathrm{~mL})$, forming a vibrant purple solution. The solution was heated at $60{ }^{\circ} \mathrm{C}$ for $24 \mathrm{~h}$, changing to a yellow color. All volatiles were removed under reduced pressure leaving a pale yellow solid. The material was dissolved in $\mathrm{Et}_{2} \mathrm{O}(2 \mathrm{~mL})$ and stored at $-25{ }^{\circ} \mathrm{C}$ for 3 days to give yellow blocks. Yield: $0.113 \mathrm{~g}, 96 \% .{ }^{1} \mathrm{H}$ NMR $\left(25^{\circ} \mathrm{C}, 400 \mathrm{MHz}, \mathrm{C}_{6} \mathrm{D}_{6}\right) \delta 0.09$ (d, $\left.3 \mathrm{H}, J_{\mathrm{HH}}=7 \mathrm{~Hz}, \mathrm{Me}_{2} \mathrm{CH}\right), 0.65\left(\mathrm{~d}, 1 \mathrm{H}, J_{\mathrm{HH}}=11 \mathrm{~Hz}, \mathrm{Ti}-\mathrm{CH}\right), 0.74(\mathrm{~s}$, 
$\left.9 \mathrm{H}, \mathrm{Me}_{3} \mathrm{C}\right), 0.79\left(\mathrm{~s}, 9 \mathrm{H}, \mathrm{Me}_{3} \mathrm{C}\right), 0.90\left(\mathrm{~d}, 6 \mathrm{H}, \mathrm{J}_{\mathrm{HH}}=7 \mathrm{~Hz}, \mathrm{Me}_{2} \mathrm{CH}\right)$, $1.00\left(\mathrm{~d}, 3 \mathrm{H}, J_{\mathrm{HH}}=6 \mathrm{~Hz}, \mathrm{Me}_{2} \mathrm{CH}\right), 1.09\left(\mathrm{~d}, 6 \mathrm{H}, J_{\mathrm{HH}}=7 \mathrm{~Hz}, \mathrm{Me}_{2} \mathrm{CH}\right)$, 1.14 (d, 7H, Me $e_{2} \mathrm{CH}$ overlapping with $\left.\mathrm{Ti}-\mathrm{CH}\right), 1.23(\mathrm{~m}, 6 \mathrm{H}$, two overlapping $\left.\mathrm{Me}_{2} \mathrm{CH}\right), 1.29\left(\mathrm{~d}, 3 \mathrm{H}, J_{\mathrm{HH}}=7 \mathrm{~Hz}, \mathrm{Me}_{2} \mathrm{CH}\right), 1.37(\mathrm{~d}, 3 \mathrm{H}$, $\left.J_{\mathrm{HH}}=7 \mathrm{~Hz}, \mathrm{Me}_{2} \mathrm{CH}\right), 1.44\left(\mathrm{~m}, 9 \mathrm{H}\right.$, two overlapping $\left.\mathrm{Me}_{2} \mathrm{CH}\right), 3.14-$ $3.20\left(\mathrm{~m}, 6 \mathrm{H}\right.$, three overlapping $\left.\mathrm{Me}_{2} \mathrm{CH}\right), 3.37\left(\mathrm{sept}, 2 \mathrm{H}, \mathrm{J}_{\mathrm{HH}}=7 \mathrm{~Hz}\right.$, $\mathrm{Me}_{2} \mathrm{CH}$ ), 3.83 (sept, $\left.1 \mathrm{H}, J_{\mathrm{HH}}=7 \mathrm{~Hz}, \mathrm{Me}_{2} \mathrm{CH}\right), 3.94$ (sept, $1 \mathrm{H}, J_{\mathrm{HH}}=$ $\left.7 \mathrm{~Hz}, \mathrm{Me}_{2} \mathrm{CH}\right), 5.79(\mathrm{~s}, 2 \mathrm{H}, \mathrm{Imid} H), 6.80\left(\mathrm{~s}, 1 \mathrm{H}, \mathrm{Ti}-\mathrm{OCHPh}_{2}\right)$, 6.99-7.25 (aryl). ${ }^{13} \mathrm{C}\left\{{ }^{1} \mathrm{H}\right\}$ NMR $\left(25{ }^{\circ} \mathrm{C}, 101 \mathrm{MHz}, \mathrm{C}_{6} \mathrm{D}_{6}\right) \delta 22.36$ $\left(\mathrm{Me}_{2} \mathrm{CH}\right), 23.00\left(\mathrm{Me}_{2} \mathrm{CH}\right), 23.07\left(\mathrm{Me}_{2} \mathrm{CH}\right), 23.32\left(\mathrm{Me}_{2} \mathrm{CH}\right), 23.63$ $\left(\mathrm{Me}_{2} \mathrm{CH}\right), 24.86\left(\mathrm{Me}_{2} \mathrm{CH}\right), 25.07\left(\mathrm{Me}_{2} \mathrm{CH}\right), 25.17\left(\mathrm{Me}_{2} \mathrm{CH}\right), 25.83$ $\left(\mathrm{Me}_{2} \mathrm{CH}\right), 26.18\left(\mathrm{Me}_{2} \mathrm{CH}\right), 26.56\left(\mathrm{Me}_{2} \mathrm{CH}\right), 27.64,27.80,28.63$ $\left(\mathrm{Me}_{2} \mathrm{CH}\right), 28.86\left(\mathrm{Me}_{2} \mathrm{CH}\right), 29.06\left(\mathrm{Me}_{2} \mathrm{CH}\right), 29.50\left(\mathrm{Me}_{3} \mathrm{C}\right), 29.87$ $\left(\mathrm{Me}_{3} \mathrm{C}\right), 35.25\left(\mathrm{Me}_{2} \mathrm{CH}\right), 43.46,43.98,79.50\left(\mathrm{Ti}-\mathrm{CH}_{2}\right), 87.57(\mathrm{Ti}-$ $\mathrm{OCHPh}_{2}$ ), 115.42 (Imid $C=C$ ), 121.99, 122.40, 123.33, 123.52, $123.60,124.20,124.64,124.91,126.22,126.71,127.65,127.95$, $129.49,129.73,140.18,140.18,142.93,143.19,144.17,145.27$, $145.47,146.00,146.36,146.42,147.32,148.24 .162 .18\left({ }^{t} \mathrm{Bu}_{2} C=\mathrm{N}\right)$, $177.20\left(\mathrm{CN}_{3}\right)$. UV-vis-NIR (toluene, $0.110 \mathrm{mM}, 25^{\circ} \mathrm{C}, \mathrm{L} \cdot \mathrm{mol}^{-1}$. $\left.\mathrm{cm}^{-1}\right) 341(\varepsilon=16010)$. IR (KBr Pellet, $\left.\mathrm{cm}^{-1}\right) 415(\mathrm{w}), 569(\mathrm{w}), 606$ $(\mathrm{w}), 627(\mathrm{w}), 639(\mathrm{w}), 703(\mathrm{~m}), 753(\mathrm{w}), 793(\mathrm{w}), 807(\mathrm{w}), 842(\mathrm{w})$, $901(w), 922(w), 940(w), 905(w), 921(w), 940(w), 975(w)$, $1016(\mathrm{w}), 1051(\mathrm{w}), 1106(\mathrm{w}), 1179(\mathrm{w}), 1215(\mathrm{w}), 1273(\mathrm{~m}), 1328$ (m), $1364(\mathrm{~m}), 1407(\mathrm{~m}), 1546(\mathrm{~s}), 1578(\mathrm{~m}), 1597(\mathrm{~m}), 1664(\mathrm{~m})$, $1678(\mathrm{~m}), 2345(\mathrm{w}), 2364(\mathrm{w}), 2870(\mathrm{~m}), 2930(\mathrm{~s}), 2963(\mathrm{~s}), 3058$ $(\mathrm{w}), 3411(\mathrm{w})$. Anal. Calcd for $\mathrm{C}_{74} \mathrm{H}_{98} \mathrm{~N}_{6} \mathrm{OTi} \cdot \mathrm{Et}_{2} \mathrm{O}: \mathrm{C}, 77.43 ; \mathrm{H}$, 9.01; N, 6.94. Found: C, 72.04; H, 8.44; N, 6.21. (Note: Duplicate combustion analyses on a single sample returned significantly inconsistent results possibly due to sample sensitivity.)

Synthesis of (ket guan) $\left(I^{\text {Dipp }} N\right) \operatorname{Ti}(F)\left(C_{6} H_{4} F\right)$ (12). A $20 \mathrm{~mL}$ scintillation vial was loaded with $1(0.100 \mathrm{~g}, 0.104 \mathrm{mmol})$ and 1,2difluorobenzene $(3 \mathrm{~mL})$, forming a dark brown solution. The solution was stirred for $12 \mathrm{~h}$ over which time the solution became yellow in color. All volatiles were removed via reduced pressure until a paleyellow solid was obtained. The material was dissolved in $\mathrm{Et}_{2} \mathrm{O}(1 \mathrm{~mL})$ followed by storage at $-25{ }^{\circ} \mathrm{C}$, giving yellow crystals after 2 days. Yield: $0.089 \mathrm{~g}, 80 \% .{ }^{1} \mathrm{H}$ NMR $\left(25^{\circ} \mathrm{C}, 400 \mathrm{MHz}, \mathrm{C}_{6} \mathrm{D}_{6}\right) \delta 0.81(\mathrm{~s}, 9 \mathrm{H}$, $\mathrm{Me}_{3} \mathrm{C}$ ), 1.00 (m, 12H, Me $\mathrm{CH}$ ), 1.03 (d, $\left.6 \mathrm{H}, \mathrm{Me}_{2} \mathrm{CH}, J_{\mathrm{HH}}=7 \mathrm{~Hz}\right)$, $1.09\left(\mathrm{~m}, 12 \mathrm{H}, M e_{2} \mathrm{CH}\right), 1.31$ (d, $\left.6 \mathrm{H}, J_{\mathrm{HH}}=7 \mathrm{~Hz}, M e_{2} \mathrm{CH}\right), 1.35$ (d, $\left.6 \mathrm{H}, J_{\mathrm{HH}}=7 \mathrm{~Hz}, \mathrm{Me}_{2} \mathrm{CH}\right), 1.40\left(\mathrm{~d}, 6 \mathrm{H}, J_{\mathrm{HH}}=7 \mathrm{~Hz}, \mathrm{Me}_{2} \mathrm{CH}\right), 3.14(\mathrm{~m}$, $8 \mathrm{H}, \mathrm{Me}_{2} \mathrm{CH}$ ), 3.66 (sept, $2 \mathrm{H}, \mathrm{J}_{\mathrm{HH}}=7 \mathrm{~Hz}, \mathrm{Me}_{2} \mathrm{CH}$ ), 3.90 (sept, $4 \mathrm{H}$, $\left.J_{\mathrm{HH}}=7 \mathrm{~Hz}, \mathrm{Me}_{2} \mathrm{CH}\right), 5.72(\mathrm{~s}, 2 \mathrm{H}, \operatorname{Imid} H), 6.50-7.20(12 \mathrm{H}$, aryl). ${ }^{13} \mathrm{C}\left\{{ }^{1} \mathrm{H}\right\}$ NMR $\left(25{ }^{\circ} \mathrm{C}, 101 \mathrm{MHz}, \mathrm{C}_{6} \mathrm{D}_{6}\right): 22.67\left(\mathrm{Me}_{2} \mathrm{CH}\right)$, 23.21 $\left(\mathrm{Me}_{2} \mathrm{CH}\right), 23.48\left(\mathrm{Me}_{2} \mathrm{CH}\right), 25.93\left(\mathrm{Me}_{2} \mathrm{CH}\right), 27.10\left(\mathrm{Me}_{2} \mathrm{CH}\right)$, $27.26\left(\mathrm{Me}_{2} \mathrm{CH}\right), 28.30\left(\mathrm{Me}_{2} \mathrm{CH}\right), 28.75\left(\mathrm{Me}_{2} \mathrm{CH}\right), 28.81\left(\mathrm{Me}_{2} \mathrm{CH}\right)$, $30.10\left(\mathrm{Me}_{3} \mathrm{C}\right), 43.66,113.58,113.88,116.64$ (Imid $\mathrm{C}=\mathrm{C}$ ), 117.47, $122.51,123.3,123.47,124.30,124.78,130.27,134.53,138.05,138.24$, $142.77,143.7,145.06,145.19,147.27,163.34,165.64,167.10,171.80$, 172.07, $172.62\left({ }^{t} \mathrm{Bu}_{2} \mathrm{C}=\mathrm{N}\right), 179.95\left(\mathrm{CN}_{3}\right) .{ }^{19} \mathrm{~F}\left\{{ }^{1} \mathrm{H}\right\}$ NMR $(376$ $\left.\mathrm{MHz}, \mathrm{C}_{6} \mathrm{D}_{6}\right) \delta-171.42\left(o-\mathrm{FC}_{6} \mathrm{H}_{4}\right)$. UV-vis-NIR (toluene, 0.193 $\left.\mathrm{mM}, 25{ }^{\circ} \mathrm{C}, \mathrm{L} \cdot \mathrm{mol}^{-1} \cdot \mathrm{cm}^{-1}\right) 380(\varepsilon=8850)$. Anal. Calcd for $\mathrm{C}_{67} \mathrm{H}_{92} \mathrm{~N}_{6} \mathrm{~F}_{2} \mathrm{Ti} \cdot \mathrm{Et}_{2} \mathrm{O}: \mathrm{C}, 74.69 ; \mathrm{H}, 8.67 ; \mathrm{N}, 7.36$. Found: C, 73.44; $\mathrm{H}$, $8.98 ; \mathrm{N}, 7.55$. (Note: Combustion analysis tested low in carbon content possibly due to poor combustion properties.)

Synthesis of (Ket guan) $\left(\mathrm{Im}^{\text {Dipp }} \mathrm{N}\right) \mathrm{Ti}(\mathrm{O})$. (13). A $50 \mathrm{~mL}$ round-bottom Cajon flask was loaded with $1(0.200 \mathrm{~g}, 0.208 \mathrm{mmol})$ and benzene $(10 \mathrm{~mL})$, forming a dark brown solution. The solution was subjected to three freeze-pump-thaw cycles and the headspace was backfilled with $\mathrm{N}_{2} \mathrm{O}(1 \mathrm{~atm})$, initially turning the solution yellow with stirring. After $10 \mathrm{~min}$, the solution turned orange in color. All volatiles were removed under reduced pressure until a shiny yellow solid was obtained. The material was dissolved in $\mathrm{Et}_{2} \mathrm{O}(2 \mathrm{~mL})$ and stored at $-25{ }^{\circ} \mathrm{C}$ for 4 days to give yellow blocks. Yield: $0.189 \mathrm{~g}, 79 \% .{ }^{1} \mathrm{H}$ NMR $\left(25^{\circ} \mathrm{C}, 400 \mathrm{MHz}, \mathrm{C}_{6} \mathrm{D}_{6}\right) \delta 0.79\left(\mathrm{~s}, 9 \mathrm{H}, \mathrm{Me}_{3} \mathrm{C}\right), 0.97(\mathrm{~d}, 6 \mathrm{H}$, $\left.J_{\mathrm{HH}}=7 \mathrm{~Hz}, \mathrm{Me}_{2} \mathrm{CH}\right), 1.01\left(\mathrm{~s}, 9 \mathrm{H}, \mathrm{Me}_{3} \mathrm{C}\right), 1.06\left(\mathrm{~d}, 6 \mathrm{H}, J_{\mathrm{HH}}=7 \mathrm{~Hz}\right.$, $\left.M e_{2} \mathrm{CH}\right), 1.18\left(\mathrm{~d}, 12 \mathrm{H}, J_{\mathrm{HH}}=4 \mathrm{~Hz}, M e_{2} \mathrm{CH}\right), 1.26\left(\mathrm{~d}, 12 \mathrm{H}, J_{\mathrm{HH}}=7\right.$ $\left.\mathrm{Hz}, \mathrm{Me}_{2} \mathrm{CH}\right), 1.34\left(\mathrm{~d}, 6 \mathrm{H}, J_{\mathrm{HH}}=7 \mathrm{~Hz}, \mathrm{Me}_{2} \mathrm{CH}\right), 3.35$ (sept, $4 \mathrm{H}, J_{\mathrm{HH}}=$ $6 \mathrm{~Hz}, \mathrm{Me}_{2} \mathrm{CH}$ ), 3.66 (sept, $2 \mathrm{H}, J_{\mathrm{HH}}=7 \mathrm{~Hz}, \mathrm{Me}_{2} \mathrm{CH}$ ), 4.70 (sept, $2 \mathrm{H}$, $\left.J_{\mathrm{HH}}=7 \mathrm{~Hz}, \mathrm{Me}_{2} \mathrm{CH}\right), 5.94(\mathrm{~s}, 2 \mathrm{H}, \operatorname{Imid} H), 7.20-7.02(12 \mathrm{H}$, aryl). ${ }^{13} \mathrm{C}\left\{{ }^{1} \mathrm{H}\right\}$ NMR $\left(25^{\circ} \mathrm{C}, 101 \mathrm{MHz}, \mathrm{C}_{6} \mathrm{D}_{6}\right) \delta 22.02\left(\mathrm{Me}_{2} \mathrm{CH}\right), 22.16$
$\left(\mathrm{Me}_{2} \mathrm{CH}\right), 23.64\left(\mathrm{Me}_{2} \mathrm{CH}\right), 24.78\left(\mathrm{Me}_{2} \mathrm{CH}\right), 25.48\left(\mathrm{Me}_{2} \mathrm{CH}\right), 28.12$, $29.12\left(\mathrm{Me}_{3} \mathrm{C}\right), 30.82\left(\mathrm{Me}_{3} \mathrm{C}\right), 43.90,115.46(\mathrm{Imid} C=C), 122.27$ (aryl), 123.75 (aryl), 124.12 (aryl), 125.27 (aryl), 129.53 (aryl), 130.57, 140.65, 143.59, 145.20, 147.73, $159.99\left({ }^{t} \mathrm{Bu}_{2} \mathrm{C}=\mathrm{N}\right), 183.43$ $\left(\mathrm{CN}_{3}\right)$. UV-vis-NIR (toluene, $\left.0.145 \mathrm{mM}, 25^{\circ} \mathrm{C}, \mathrm{L} \cdot \mathrm{mol}^{-1} \cdot \mathrm{cm}^{-1}\right) 330$ $(\varepsilon=4719), 415(\varepsilon=997)$. Anal. Calcd for $\mathrm{C}_{61} \mathrm{H}_{88} \mathrm{~N}_{6} \mathrm{OTi}: \mathrm{C}$, 75.57; $\mathrm{H}, 9.37 ; \mathrm{N}$, 8.11. Found: C, 73.29; H, 9.16; N, 8.67. (Note: Combustion analysis of independently prepared samples consistently tested low in carbon content.)

Synthesis of ( ${ }^{\text {Ket }}$ guan) $\left({ }^{\prime m^{D i p p}} N\right) T i(S)$ (14). To a thawing solution of $1(0.100 \mathrm{~g}, 0.104 \mathrm{mmol})$ in benzene $(5 \mathrm{~mL})$ was added $\mathrm{S}=\mathrm{PPh}_{3}$ $(0.031 \mathrm{~g}, 0.104 \mathrm{mmol})$ in one portion. The addition was accompanied by an instantaneous color change to dark red. After $5 \mathrm{~min}$, all volatiles were removed via reduced pressure until a dark solid was obtained. The material was dissolved in $\mathrm{Et}_{2} \mathrm{O}(1 \mathrm{~mL})$ followed by storage at $-25{ }^{\circ} \mathrm{C}$, giving dark maroon crystals after 2 days. Yield: $0.063 \mathrm{~g}, 61 \%$. ${ }^{1} \mathrm{H}$ NMR $\left(25^{\circ} \mathrm{C}, 400 \mathrm{MHz}, \mathrm{C}_{6} \mathrm{D}_{6}\right) \delta 0.74\left(\mathrm{~d}, 6 \mathrm{H}, J_{\mathrm{HH}}=7 \mathrm{~Hz}\right.$, $\mathrm{Me}_{2} \mathrm{CH}$ ), 0.76 (s, 9H, $\mathrm{Me}_{3} \mathrm{C}$ ), 1.09 (d, 6H, $J_{\mathrm{HH}}=7 \mathrm{~Hz}, \mathrm{Me}_{2} \mathrm{CH}$ ), 1.16 $\left.\left(\mathrm{d}, 12 \mathrm{H}, J_{\mathrm{HH}}=7 \mathrm{~Hz}, \mathrm{Me}_{2} \mathrm{CH}\right) 1.18\left(\mathrm{~s}, 9 \mathrm{H}, M e_{3} \mathrm{C}\right),\right) 1.29$ (m, 18H, two overlapping $\mathrm{Me}_{2} \mathrm{CH}$ ), 1.46 (d, $6 \mathrm{H}, \mathrm{J}_{\mathrm{HH}}=7 \mathrm{~Hz}, \mathrm{Me}_{2} \mathrm{CH}$ ), 3.45 (sept, $4 \mathrm{H}, J_{\mathrm{HH}}=7 \mathrm{~Hz}, \mathrm{Me}_{2} \mathrm{CH}$ ), 3.55 (sept, $2 \mathrm{H}, J_{\mathrm{HH}}=7 \mathrm{~Hz}, \mathrm{Me}_{2} \mathrm{CH}$ ), 5.39 (sept, $2 \mathrm{H}, J_{\mathrm{HH}}=7 \mathrm{~Hz}, \mathrm{Me}_{2} \mathrm{CH}$ ), 5.97 (s, $\left.2 \mathrm{H}, \mathrm{ImidNH}\right), 6.99-7.16$ (12H, aryl). ${ }^{13} \mathrm{C}\left\{{ }^{1} \mathrm{H}\right\}$ NMR $\left(25{ }^{\circ} \mathrm{C}, 101 \mathrm{MHz}, \mathrm{C}_{6} \mathrm{D}_{6}\right) \delta 22.11$ $\left(\mathrm{Me}_{2} \mathrm{CH}\right), 23.16\left(\mathrm{Me}_{2} \mathrm{CH}\right), 25.20\left(\mathrm{Me}_{3} \mathrm{C}\right), 25.53\left(\mathrm{Me}_{2} \mathrm{CH}\right), 28.1$ $\left(\mathrm{Me}_{2} \mathrm{CH}\right), 29.04\left(\mathrm{Me}_{2} \mathrm{CH}\right), 29.11\left(\mathrm{Me}_{2} \mathrm{CH}\right), 30.81\left(\mathrm{Me}_{3} \mathrm{C}\right), 116.31$ (Imid $C=C$ ), 122.23 (aryl), 124.44 (aryl), 124.49 (aryl), 125.71, 129.94 (aryl), 134.81 141.08 143.47, 146.24, 147.3, 148.33, 161.31 $\left({ }^{t} \mathrm{Bu}_{2} \mathrm{C}=\mathrm{N}\right), 184.47\left(\mathrm{CN}_{3}\right) . \mathrm{UV}$-vis-NIR (toluene, $0.089 \mathrm{mM}, 25$ $\left.{ }^{\circ} \mathrm{C}, \mathrm{L} \cdot \mathrm{mol}^{-1} \cdot \mathrm{cm}^{-1}\right) 350(\varepsilon=2693), 360(\varepsilon=2838), 545(\varepsilon=161)$. IR (KBr Pellet, $\left.\mathrm{cm}^{-1}\right) 499(\mathrm{~m}), 520(\mathrm{~m}), 537(\mathrm{w}), 554(\mathrm{w}), 600(\mathrm{w})$, $686(\mathrm{~m}), 718(\mathrm{w}), 750(\mathrm{~s}), 793(\mathrm{~s}), 807(\mathrm{~m}), 922(\mathrm{~m}), 935(\mathrm{~m}), 973$ (m), $1015(\mathrm{w}), 1108(\mathrm{~m}), 1178(\mathrm{~m}), 1213(\mathrm{~s}), 1264(\mathrm{~s}), 1321(\mathrm{~s})$, $1364(\mathrm{~s}), 1385$ (s), 1431 (s), $1460(\mathrm{~s}), 1519$ (s), $1578(\mathrm{~s}), 1600(\mathrm{~s})$, 1620 (s), 1679 (s), 2867 (s), 2927 (s), $2964(\mathrm{~s}), 3060(\mathrm{w}), 3148(\mathrm{w})$, $3182(\mathrm{w}), 3326,3396(\mathrm{w})$. Anal. Calcd for $\mathrm{C}_{61} \mathrm{H}_{88} \mathrm{~N}_{6} \mathrm{STi}$ : C, 74.29; H, 9.01; N, 8.52. Found: C, 74.27; H, 9.05; N, 8.30.

Synthesis of ( ${ }^{\text {Ket }}$ guan) $\left(\mathrm{Im}^{\mathrm{Dipp}} \mathrm{N}\right) \mathrm{Ti}(\mathrm{Se})$ (15). To a thawing solution of $\mathbf{1}(0.100 \mathrm{~g}, 0.104 \mathrm{mmol})$ in benzene $(5 \mathrm{~mL})$ was added $\mathrm{Ph}_{3} \mathrm{P}=\mathrm{Se}$ $(0.036 \mathrm{~g}, 0.104 \mathrm{mmol})$ in one portion. Upon stirring, the solution gradually turned green over $12 \mathrm{~h}$. All volatiles were removed via reduced pressure until a green solid was obtained. The material dissolved in $\mathrm{Et}_{2} \mathrm{O}(2 \mathrm{~mL})$ and was stored at $-25{ }^{\circ} \mathrm{C}$, giving green crystals after 2 days. Yield: $0.073 \mathrm{~g}, 71 \% .{ }^{1} \mathrm{H}$ NMR $\left(25^{\circ} \mathrm{C}, 400 \mathrm{MHz}\right.$, $\left.\mathrm{C}_{6} \mathrm{D}_{6}\right) \delta 0.66\left(\mathrm{~d}, 6 \mathrm{H}, J_{\mathrm{HH}}=7 \mathrm{~Hz}, \mathrm{Me}_{2} \mathrm{CH}\right), 0.76\left(\mathrm{~s}, 9 \mathrm{H}, \mathrm{Me}_{3} \mathrm{C}\right) 1.09$ $\left(\mathrm{d}, 6 \mathrm{H}, J_{\mathrm{HH}}=7 \mathrm{~Hz}, \mathrm{Me}_{2} \mathrm{CH}\right), 1.17\left(\mathrm{~d}, 12 \mathrm{H}, J_{\mathrm{HH}}=7 \mathrm{~Hz}, \mathrm{Me}_{2} \mathrm{CH}\right) 1.26$ (s, $\left.9 \mathrm{H}, \mathrm{Me}_{3} \mathrm{C}\right), 1.32$ (m, $18 \mathrm{H}$, two overlapping $\left.\mathrm{Me}_{2} \mathrm{CH}\right), 1.50(\mathrm{~d}, 6 \mathrm{H}$, $J_{\mathrm{HH}}=7 \mathrm{~Hz}, \mathrm{Me}_{2} \mathrm{CH}$ ), 3.35 (sept, $2 \mathrm{H}, J_{\mathrm{HH}}=7 \mathrm{~Hz}, \mathrm{Me}_{2} \mathrm{CH}$ ), 3.64 (sept, $4 \mathrm{H}, J_{\mathrm{HH}}=7 \mathrm{~Hz}, \mathrm{Me}_{2} \mathrm{CH}$ ), 5.55 (sept, $2 \mathrm{H}, J_{\mathrm{HH}}=7 \mathrm{~Hz}, \mathrm{Me}_{2} \mathrm{CH}$ ), $6.00\left(\mathrm{~s}, 2 \mathrm{H}\right.$, ImidNH), 6.99-7.16 $(12 \mathrm{H}$, aryl $) .{ }^{13} \mathrm{C}\left\{{ }^{1} \mathrm{H}\right\} \operatorname{NMR}\left(25^{\circ} \mathrm{C}\right.$, $\left.101 \mathrm{MHz}, \mathrm{C}_{6} \mathrm{D}_{6}\right) \delta 22.07\left(\mathrm{Me}_{2} \mathrm{CH}\right), 23.30\left(\mathrm{Me}_{2} \mathrm{CH}\right), 24.06$ $\left(\mathrm{Me}_{2} \mathrm{CH}\right), 25.27\left(\mathrm{Me}_{2} \mathrm{CH}\right), 25.48\left(\mathrm{Me}_{2} \mathrm{CH}\right), 26.98\left(\mathrm{Me}_{2} \mathrm{CH}\right), 28.39$ $\left(\mathrm{Me}_{2} \mathrm{CH}\right), 28.64\left(\mathrm{Me}_{2} \mathrm{CH}\right), 29.25\left(\mathrm{Me}_{3} \mathrm{C}\right), 30.77\left(\mathrm{Me}_{3} \mathrm{C}\right), 116.02$ (Imid $C=C$ ), 122.26, (aryl), 124.57 (aryl), 125.77 (aryl), 128.59 (aryl), 128.80 (aryl), 128.87 (aryl), 130.02 (aryl), 141.26, 143.41, $146.23,147.20,147.75,161.74\left({ }^{t} \mathrm{Bu}_{2} \mathrm{C}=\mathrm{N}\right) 184.5\left(\mathrm{CN}_{3}\right) . \mathrm{UV}-\mathrm{vis}-$ NIR (toluene, $\left.0.102 \mathrm{mM}, 25{ }^{\circ} \mathrm{C}, \mathrm{L} \cdot \mathrm{mol}^{-1} \cdot \mathrm{cm}^{-1}\right) 415(\varepsilon=2440)$. IR (KBr Pellet, $\mathrm{cm}^{-1}$ ) $499(\mathrm{~m}), 520(\mathrm{~m}), 537(\mathrm{w}), 554(\mathrm{w}), 600(\mathrm{w})$, $686(\mathrm{~m}), 718(\mathrm{w}), 750(\mathrm{~s}), 793(\mathrm{~s}), 807(\mathrm{~m}), 922(\mathrm{~m}), 935(\mathrm{~m}), 973$ $(\mathrm{m}), 1015(\mathrm{w}), 1108(\mathrm{~m}), 1178(\mathrm{~m}), 1213(\mathrm{~s}), 1264(\mathrm{~s}), 1321(\mathrm{~s})$, 1364 (s), 1385 (s), 1431 (s), 1460 (s), 1519 (s), $1578(\mathrm{~s}), 1600(\mathrm{~s})$, $1620(\mathrm{~s}), 1679$ (s), 2867 (s), 2927 (s), $2964(\mathrm{~s}), 3060(\mathrm{w}), 3148(\mathrm{w})$, $3182(\mathrm{w}), 3326,3396(\mathrm{w})$. Anal. Calcd for $\mathrm{C}_{61} \mathrm{H}_{88} \mathrm{~N}_{6} \mathrm{SeTi} \cdot \mathrm{Et}_{2} \mathrm{O}$ : C, 70.55; H, 8.94; N, 7.59. Found: C, 69.31; H, 9.29; N, 7.66. (Note: Combustion analysis of independently prepared samples consistently tested low in carbon content.)

Synthesis of (Ket guan) $\left(\operatorname{Im}^{\mathrm{Dipp}} N\right) \mathrm{Ti}\left(\eta^{2}-S_{2}\right)$ (16). To a thawing solution of $1(0.100 \mathrm{~g}, 0.104 \mathrm{mmol})$ in benzene $(5 \mathrm{~mL})$ was added propylene sulfide $(0.120 \mathrm{~g}, 0.128 \mathrm{~mL}, 1.700 \mathrm{mmol})$ with stirring, turning dark maroon. After $10 \mathrm{~min}$, all volatiles were removed via reduced pressure until a dark maroon solid was obtained. The 
material was dissolved in $\mathrm{Et}_{2} \mathrm{O}(3 \mathrm{~mL})$ followed by storage at $-25^{\circ} \mathrm{C}$, giving dark maroon crystals after 3 days. Yield: $0.091 \mathrm{~g}, 86 \% .{ }^{1} \mathrm{H}$ NMR $\left(25^{\circ} \mathrm{C}, 400 \mathrm{MHz}, \mathrm{C}_{6} \mathrm{D}_{6}\right) \delta 0.72(\mathrm{~s} 9 \mathrm{H}), 0.90(\mathrm{~m}, 9 \mathrm{H}), 1.03(\mathrm{~s}$, $18 \mathrm{H}), 1.09(\mathrm{~m}, 12 \mathrm{H}), 1.39\left(\mathrm{~m}, 16 \mathrm{H}, J_{\mathrm{HH}}=7 \mathrm{~Hz}, M e_{2} \mathrm{CH}\right), 3.73$ (sept, $2 \mathrm{H}, J_{\mathrm{HH}}=7 \mathrm{~Hz}, \mathrm{Me}_{2} \mathrm{CH}$ ), 4.24 (sept, $2 \mathrm{H}, J_{\mathrm{HH}}=7 \mathrm{~Hz}, \mathrm{Me}_{2} \mathrm{CH}$ ), 7.00$7.14\left(12 \mathrm{H}\right.$, aryl). ${ }^{13} \mathrm{C}\left\{{ }^{1} \mathrm{H}\right\}$ NMR $\left(25{ }^{\circ} \mathrm{C}, 101 \mathrm{MHz}, \mathrm{C}_{6} \mathrm{D}_{6}\right): 22.20$ $\left(\mathrm{Me}_{2} \mathrm{CH}\right), 23.56\left(\mathrm{Me}_{2} \mathrm{CH}\right), 26.36\left(\mathrm{Me}_{2} \mathrm{CH}\right), 28.21\left(\mathrm{Me}_{2} \mathrm{CH}\right), 29.07$ $\left(\mathrm{Me}_{3} \mathrm{C}\right), 29.75\left(\mathrm{Me}_{2} \mathrm{CH}\right), 30.29\left(\mathrm{Me}_{2} \mathrm{CH}\right), 30.82\left(\mathrm{Me}_{3} \mathrm{C}\right), 116.54$ (Imid $C=C$ ), 122.12 (aryl), 124.47 (aryl), 125.40 (aryl), 130.16 (aryl), 134.57, 142.28, 144.49, 146.22, $166.16\left({ }^{t} \mathrm{Bu}_{2} \mathrm{C}=\mathrm{N}\right), 182.83$ $\left({ }^{t} \mathrm{Bu}_{2} \mathrm{C}=\mathrm{N}\right)$. UV-vis-NIR (toluene, $0.012 \mathrm{mM}, 25{ }^{\circ} \mathrm{C}, \mathrm{L} \cdot \mathrm{mol}^{-1}$. $\left.\mathrm{cm}^{-1}\right) 335(\varepsilon=12132), 393(\varepsilon=9564), 516(\varepsilon=2575)$. Anal. Calcd for $\mathrm{C}_{61} \mathrm{H}_{88} \mathrm{~N}_{6} \mathrm{~S}_{2} \mathrm{Ti} \cdot \mathrm{Et}_{2} \mathrm{O}: \mathrm{C}, 71.50 ; \mathrm{H}, 9.05 ; \mathrm{N}, 7.70$. Found: C, 68.05; $\mathrm{H}, 9.02 ; \mathrm{N}, 6.71$. (Note: Combustion analysis consistently gave unsatisfactory results possibly due to poor combustion properties.)

Synthesis of ( ${ }^{\text {Ket }}$ guan) $\left(\mathrm{Im}^{\mathrm{Dipp}} \mathrm{N}\right) \mathrm{Ti}\left(\mathrm{NSiMe}_{3}\right)$ (17). To a thawing solution of $1(0.100 \mathrm{~g}, 0.104 \mathrm{mmol})$ in benzene $(5 \mathrm{~mL})$ was added trimethylsilyl azide $(0.138 \mathrm{~g}, 0.181 \mathrm{~mL}, 0.120 \mathrm{mmol})$ in one portion via a micropipette. Upon stirring, a gradual change to red was observed. After $5 \mathrm{~min}$, all volatiles were removed via reduced pressure until a red solid was obtained. The material was dissolved in $\mathrm{Et}_{2} \mathrm{O}$ ( 1 $\mathrm{mL}$ ) followed by storage at $-25{ }^{\circ} \mathrm{C}$, giving red-orange crystals after 2 days. Crystals were dried under reduced pressure to afford a redorange solid. Yield: $0.096 \mathrm{~g}, 88 \% .{ }^{1} \mathrm{H}$ NMR $\left(25^{\circ} \mathrm{C}, 400 \mathrm{MHz}, \mathrm{C}_{6} \mathrm{D}_{6}\right)$ $\delta 0.23\left(\mathrm{~s}, 9 \mathrm{H}, \mathrm{Me}_{3} \mathrm{Si}\right), 0.75\left(\mathrm{~s}, 9 \mathrm{H}, \mathrm{Me}_{3} \mathrm{C}\right), 0.87\left(\mathrm{~d}, 6 \mathrm{H}, J_{\mathrm{HH}}=7 \mathrm{~Hz}\right)$, $1.03\left(\mathrm{~s}, 9 \mathrm{H}, M e_{3} \mathrm{C}\right), 1.07\left(\mathrm{~d}, 6 \mathrm{H}, J_{\mathrm{HH}}=7 \mathrm{~Hz}, M e_{2} \mathrm{CH}\right), 1.19(\mathrm{~d}, 12 \mathrm{H}$, $\left.J_{\mathrm{HH}}=7 \mathrm{~Hz}, M e_{2} \mathrm{CH}\right), 1.32\left(\mathrm{~d}, 6 \mathrm{H}, J_{\mathrm{HH}}=7 \mathrm{~Hz}, M e_{2} \mathrm{CH}\right), 1.38(\mathrm{~d}, 6 \mathrm{H}$, $\left.J_{\mathrm{HH}}=7 \mathrm{~Hz}, \mathrm{Me}_{2} \mathrm{CH},\right), 1.50\left(\mathrm{~d}, 6 \mathrm{H}, J_{\mathrm{HH}}=7 \mathrm{~Hz}, \mathrm{Me}_{2} \mathrm{CH}\right), 3.38$ (sept, $4 \mathrm{H}, J_{\mathrm{HH}}=7 \mathrm{~Hz}, \mathrm{Me}_{2} \mathrm{CH}$ ), 3.62 (sept, $2 \mathrm{H}, J_{\mathrm{HH}}=7 \mathrm{~Hz}, \mathrm{Me}_{2} \mathrm{CH}$ ), 4.73 (sept, $2 \mathrm{H}, J_{\mathrm{HH}}=7 \mathrm{~Hz}, \mathrm{Me}_{2} \mathrm{CH}$ ), 5.90 (s, 2H, ImidNH), 7.02-7.20 (12H, aryl protons). ${ }^{13} \mathrm{C}\left\{{ }^{1} \mathrm{H}\right\}$ NMR $\left(25^{\circ} \mathrm{C}, 101 \mathrm{MHz}, \mathrm{C}_{6} \mathrm{D}_{6}\right) \delta 4.72$ $\left(\mathrm{Me}_{3} \mathrm{Si}\right), 21.97\left(\mathrm{Me}_{2} \mathrm{CH}\right), 22.94\left(\mathrm{Me}_{2} \mathrm{CH}\right), 23.96\left(\mathrm{Me}_{2} \mathrm{CH}\right), 24.84$ $\left(\mathrm{Me}_{2} \mathrm{CH}\right), 25.74\left(\mathrm{Me}_{2} \mathrm{CH}\right), 27.46\left(\mathrm{Me}_{2} \mathrm{CH}\right), 28.98\left(\mathrm{Me}_{2} \mathrm{CH}\right), 29.419$, $29.26\left(\mathrm{Me}_{3} \mathrm{C}\right), 29.26\left(\mathrm{Me}_{2} \mathrm{CH}\right), 30.84\left(\mathrm{Me}_{3} \mathrm{C}\right), 115.35$ (Imid $\mathrm{C}=\mathrm{C}$ ), 122.33 (aryl), 123.98, 124.82 (aryl), 125.18 (aryl), 128.59, 129.19 (aryl), 135.54, 141.8, 144.13, 145.49, 146.95, $161.81\left({ }^{t} \mathrm{Bu}_{2} \mathrm{C}=\mathrm{N}\right)$, $182.57\left(\mathrm{CN}_{3}\right)$. UV-vis-NIR (toluene, $0.135 \mathrm{mM}, 25^{\circ} \mathrm{C}, \mathrm{L} \cdot \mathrm{mol}^{-1}$. $\left.\mathrm{cm}^{-1}\right) 365(\varepsilon=5222), 484(\varepsilon=644)$. IR (KBr Pellet, $\left.\mathrm{cm}^{-1}\right)$ 674(w), $751(\mathrm{~m}), 794(\mathrm{~m}), 802(\mathrm{w}), 839(\mathrm{~m}), 891(\mathrm{w}), 913(\mathrm{w}), 936(\mathrm{~m})$ $972(\mathrm{~m}), 1011(\mathrm{w}), 1078(\mathrm{~m}), 1092(\mathrm{~m}), 1047(\mathrm{w}), 1182(\mathrm{w}), 1246$ $(\mathrm{m}), 1326(\mathrm{~m}), 1364(\mathrm{~s}), 1362(\mathrm{~s}), 1385(\mathrm{~s}), 1432(\mathrm{~s}), 1462(\mathrm{~s})$, 1558 (s), 1598 (s), 1675 (s), 2867 (s), 2927 (s), 3059 (w), 3137 (w), $3386(w)$. Anal. Calcd for $\mathrm{C}_{64} \mathrm{H}_{97} \mathrm{~N}_{7} \mathrm{SiTi} \cdot \mathrm{Et}_{2} \mathrm{O}: \mathrm{C}, 73.28 ; \mathrm{H}, 9.68 ; \mathrm{N}$ 8.80. Found: C,73.11; H, 9.62; N, 8.83.

Synthesis of $\left[\left(\mathrm{Im}^{\mathrm{Dipp}} N\right)\left({ }^{\text {Ket }}\right.\right.$ guan $\left.) T i(N A d)\right]$ (18). To a thawing solution of $1(0.100 \mathrm{~g}, 0.104 \mathrm{mmol})$ in benzene $(15 \mathrm{~mL})$ was added 1-azidoadamantane $(0.016 \mathrm{~g}, 0.090 \mathrm{mmol})$ in one portion. Upon stirring, the reaction immediately turned red. After $5 \mathrm{~min}$, all volatiles were removed via reduced pressure until a dark red solid was obtained. The material dissolved in $\mathrm{Et}_{2} \mathrm{O}(2 \mathrm{~mL})$ followed by storage at $-25{ }^{\circ} \mathrm{C}$, giving dark red crystals after 4 days. Yield: $0.062 \mathrm{~g}, 81 \%$. ${ }^{1} \mathrm{H}$ NMR $\left(25^{\circ} \mathrm{C}, 400 \mathrm{MHz}, \mathrm{C}_{6} \mathrm{D}_{6}\right) \delta 0.78\left(\mathrm{~s}, 9 \mathrm{H}, \mathrm{Me}_{3} \mathrm{C}\right), 0.84(\mathrm{~d}, 6 \mathrm{H}$, $\left.J_{\mathrm{HH}}=7 \mathrm{~Hz}, \mathrm{Me}_{2} \mathrm{CH}\right), 1.08\left(\mathrm{~s}, 9 \mathrm{H}, \mathrm{Me}_{3} \mathrm{C}\right), 1.13\left(\mathrm{~d}, 6 \mathrm{H}, J_{\mathrm{HH}}=6 \mathrm{~Hz}\right.$, $\left.\mathrm{Me}_{2} \mathrm{CH}\right), 1.19\left(\mathrm{~d}, 12 \mathrm{H}, J_{\mathrm{HH}}=7 \mathrm{~Hz}, \mathrm{Me}_{2} \mathrm{CH}\right), 1.32\left(\mathrm{~d}, 12 \mathrm{H}, J_{\mathrm{HH}}=7\right.$ $\mathrm{Hz}, \mathrm{Me}_{2} \mathrm{CH}$ ), 1.38 (d, $\left.6 \mathrm{H}, J_{\mathrm{HH}}=7 \mathrm{~Hz}, M e_{2} \mathrm{CH}\right), 1.50\left(\mathrm{~d}, 6 \mathrm{H}, J_{\mathrm{HH}}=7\right.$ $\mathrm{Hz}, \mathrm{Me}_{2} \mathrm{CH}$ ), 1.74 (b, $12 \mathrm{H}$, adamantyl), 2.13 (s, 3H, adamantyl), 3.38 (sept, $4 \mathrm{H}, J_{\mathrm{HH}}=7 \mathrm{~Hz}, \mathrm{Me}_{2} \mathrm{CH}$ ), $3.62\left(\right.$ sept $, 2 \mathrm{H}, J_{\mathrm{HH}}=7 \mathrm{~Hz}, \mathrm{Me}_{2} \mathrm{CH}$ ), 4.73 (sept, $2 \mathrm{H}, J_{\mathrm{HH}}=7 \mathrm{~Hz}, \mathrm{Me}_{2} \mathrm{CH}$ ), 5.90 (s, $2 \mathrm{H}, \operatorname{ImidNH}$ ), 7.20$7.02(12 \mathrm{H}$, aryl $) .{ }^{13} \mathrm{C}\left\{{ }^{1} \mathrm{H}\right\}$ NMR $\left(25{ }^{\circ} \mathrm{C}, 101 \mathrm{MHz}, \mathrm{C}_{6} \mathrm{D}_{6}\right) \delta 21.98$ $\left(\mathrm{Me}_{2} \mathrm{CH}\right), 23.53\left(\mathrm{Me}_{2} \mathrm{CH}\right), 24.05\left(\mathrm{Me}_{2} \mathrm{CH}\right), 25.10\left(\mathrm{Me}_{2} \mathrm{CH}\right), 25.77$ $\left(\mathrm{Me}_{2} \mathrm{CH}\right), 26.98\left(\mathrm{Me}_{2} \mathrm{CH}\right), 29.04\left(\mathrm{Me}_{2} \mathrm{CH}\right), 29.16\left(\mathrm{Me}_{2} \mathrm{CH}\right), 29.31$ $\left(\mathrm{Me}_{3} \mathrm{C}\right), 29.41\left(\mathrm{Me}_{3} \mathrm{C}\right), 30.77\left(\mathrm{Me}_{3} \mathrm{C}\right), 30.88$ (adamantyl), 35.96, 37.33 (adamantyl), 43.53, 44.59 (adamantyl), 45.36 (adamantyl), 115.02 (Imid $C=C$ ), 122.33, 124.16 (aryl), 124.77 (aryl), 128.93 (aryl), 135.97, 142.55, 144.43, 144.53, 145.01, 147.08, 161.74 $\left({ }^{t} \mathrm{Bu}_{2} \mathrm{C}=\mathrm{N}\right), 185.50\left(\mathrm{CN}_{3}\right)$. UV-vis-NIR (toluene, $0.194 \mathrm{mM}, 25$ $\left.{ }^{\circ} \mathrm{C}, \mathrm{L} \cdot \mathrm{mol}^{-1} \cdot \mathrm{cm}^{-1}\right) 323(\varepsilon=9284), 382(\varepsilon=3298), 526(\varepsilon=301)$. IR (KBr Pellet, $\mathrm{cm}^{-1}$ ) $415(\mathrm{w}), 432(\mathrm{w}), 473(\mathrm{w}), 507(\mathrm{w}), 556(\mathrm{w}), 573$ $(\mathrm{w}), 609(\mathrm{w}), 675(\mathrm{w}), 751(\mathrm{~m}), 793(\mathrm{w}), 893(\mathrm{~m}), 945(\mathrm{~m}), 973$ (m), $1050(\mathrm{~m}), 1113(\mathrm{~m}), 1178(\mathrm{w}), 1218(\mathrm{~m}), 1262(\mathrm{~m}), 1330(\mathrm{~m})$,
1364 (s), 1386 (s), 1434 (s), 1456 (s), 1559 (s), 1598 (s), 2677 (s), $2087(\mathrm{~m}), 2870(\mathrm{~s}), 2908$ (s), $2962(\mathrm{~s}), 3060$ (m). Anal. Calcd for $\mathrm{C}_{71} \mathrm{H}_{103} \mathrm{~N}_{7} \mathrm{Ti}: \mathrm{C}, 77.35 ; \mathrm{H}, 9.42 ; \mathrm{N}, 8.89$. Found: C, 76.97.05; H, 9.57; N, 8.25.

Cyclic Voltammetry. Cyclic voltammetric measurements were performed using a $\mathrm{CH}$ Instruments 600e potentiostat with a PC unit controlled with $\mathrm{CHI}$ software (version 13.12). Experiments were performed in a glovebox under an inert $\mathrm{N}_{2}$ atm using platinum disks ( $2 \mathrm{~mm}$ diameter) embedded in Kel-F thermoplastic as the counter and working electrodes, while the reference electrode consisted of a platinum wire. Solutions utilized in the electrochemical studies were approximately $1 \mathrm{mM}$ in $2^{\mathrm{Cl}}$ with $\left[\mathrm{NBu}_{4}\right]\left[\mathrm{PF}_{6}\right](0.2 \mathrm{M}$, THF) as supporting electrolyte. All potentials are reported versus the $\left[\mathrm{Cp}_{2} \mathrm{Fe}\right]^{0 /+}$ couple, referenced as internal standard.

X-ray Structure Solution and Refinement. Single crystal X-ray studies for reported structures $3 \cdot \mathrm{Et}_{2} \mathrm{O}, 4 \cdot \mathrm{THF}, 6 \cdot 2 \mathrm{C}_{6} \mathrm{H}_{6}, 7 \cdot 5 \mathrm{THF}, \mathbf{1 1}$. $\mathrm{Et}_{2} \mathrm{O}, \mathbf{1 3} \cdot \mathrm{Et}_{2} \mathrm{O}, \mathbf{1 4} \cdot \mathrm{Et}_{2} \mathrm{O}, \mathbf{1 7} \cdot \mathrm{Et}_{2} \mathrm{O}$, and $18 \cdot \mathrm{Et}_{2} \mathrm{O}$ were carried out using a Bruker 3-axis platform diffractometer equipped with an APEX I CCD detector using a graphite monochromator with a Mo $\mathrm{K} \alpha \mathrm{X}$-ray source $(\lambda=0.71073 \AA)$ at $100(2) \mathrm{K}$ under a flow of nitrogen gas during data collection. Alternatively, data for structures $9 \cdot \mathrm{Et}_{2} \mathrm{O}, \mathbf{1 0}$ $\mathrm{Et}_{2} \mathrm{O}, \mathbf{1 2}, \mathbf{1 5} \cdot \mathrm{Et}_{2} \mathrm{O}$ and $\mathbf{1 6} \cdot \mathrm{C}_{6} \mathrm{H}_{14}$ were collected at ChemMatCARS located at the Advanced Photon Source (APS), Argonne National Laboratory (ANL), using synchrotron radiation $(\lambda=0.41328 \AA)$ in conjunction with a Bruker D8 three-circle platform goniometer equipped with Dectris PILATUS 100 detector under a nitrogen cryosteam at $100(2) \mathrm{K}$. Crystals were mounted on a glass fiber or on a Mitigen Kapton loop using NVH crystallographic immersion oil. Data was collected using $\varphi$ and $\omega$ scan collection strategies. Data collection and cell parameter determination were conducted using the SMART $^{114}$ program. Integration of the data and final cell parameter refinements were performed using SAINT ${ }^{115}$ software with data absorption correction implemented through SADABS. ${ }^{116}$ Structures were solved using direct, charge flipping, or intrinsic phasing methods and difference Fourier techniques. All hydrogen atom positions were idealized and rode on the atom of attachment with the exception of those that exhibit disorder. Structure solutions and structure refinements were completed using direct methods determinations in SHELXTL ${ }^{117}$ or Olex $2^{118}$ crystallographic package.

The cocrystallized solvent molecules for $3 \cdot \mathrm{Et}_{2} \mathrm{O}, 7 \cdot 5 \mathrm{THF}, 14 \cdot \mathrm{Et}_{2} \mathrm{O}$, $15 \cdot \mathrm{Et}_{2} \mathrm{O}, 16 \cdot \mathrm{C}_{6} \mathrm{H}_{14}$, and $18 \cdot \mathrm{Et}_{2} \mathrm{O}$ exhibit positional disorder, and the solvent molecules were modeled accordingly in more than one orientation with assigned occupancies as appropriate. Full positional disorder was observed for $9 \cdot \mathrm{Et}_{2} \mathrm{O}$ and $\mathbf{1 8} \cdot \mathrm{Et}_{2} \mathrm{O}$, which was confirmed by modeling in space groups of lower symmetry. The disorder was addressed by modeling the molecules in two orientations with the disordered atoms assigned half occupancies. Furthermore, the disorder in $18 \cdot \mathrm{Et}_{2} \mathrm{O}$ prevented satisfactory anisotropic refinement of the affected atoms. A summary of relevant crystallographic data is presented in Table S1.

\section{ASSOCIATED CONTENT}

\section{S Supporting Information}

The Supporting Information is available free of charge on the ACS Publications website at DOI: 10.1021/acs.organomet.9b00637.

NMR, EPR, UV-vis, and IR spectral data, solid-state molecular structures of $14 \cdot \mathrm{Et}_{2} \mathrm{O}, \mathbf{1 5} \cdot \mathrm{Et}_{2} \mathrm{O}, \mathbf{1 6} \cdot \mathrm{C}_{6} \mathrm{H}_{14}$ and 18. $\mathrm{Et}_{2} \mathrm{O}(\mathrm{PDF})$

\section{Accession Codes}

CCDC 1946723 and 1956393-1956405 contain the supplementary crystallographic data for this paper. These data can be obtained free of charge via www.ccdc.cam.ac.uk/data_request/ cif, or by emailing data request@ccdc.cam.ac.uk, or by contacting The Cambridge Crystallographic Data Centre, 12 Union Road, Cambridge CB2 1EZ, UK; fax: +44 1223336033. 


\section{AUTHOR INFORMATION}

\section{Corresponding Author}

*E-mail: asfortier@utep.edu.

ORCID $\odot$

Skye Fortier: 0000-0002-0502-5229

\section{Notes}

The authors declare no competing financial interest.

\section{ACKNOWLEDGMENTS}

We are grateful to the ACS Petroleum Research Fund (ACSPRF 57132-DNI3; S.F.), the Welch Foundation (AH-192220170325; S.F.), and the NSF PREM Program (DMR1827745) for financial support of this work. S.F. is an Alfred P. Sloan Foundation research fellow and is thankful for their support. S.F. and J.M. are awardees of the Faculty and Student Team Research Award at ChemMatCARS (FaSTRAC). NSF's ChemMatCARS Sector 15 is principally supported by the Divisions of Chemistry (CHE) and Materials Research (DMR), National Science Foundation, under grant number NSF/CHE-1834750. Use of the Advanced Photon Source, an Office of Science User Facility operated for the U.S. Department of Energy (DOE) Office of Science by Argonne National Laboratory, was supported by the U.S. DOE under Contract No. DE-AC02-06CH11357. We thank Dr. Sohan de Silva for assistance with the EPR measurements. We also thank Prof. Joshua Telser for helpful discussions.

\section{REFERENCES}

(1) Hilt, G.; Punner, F.; Mobus, J.; Naseri, V.; Bohn, M. A. A Lewis Acidity Scale in Relation to Rate Constants of Lewis Acid Catalyzed Organic Reactions. Eur. J. Org. Chem. 2011, 2011, 5962-5966.

(2) Xiu, W.; Zhenhua, W.; Zhang, G.; Zhang, W.; Wu, Y.; Gao, Z. Tunable Titanocene Lewis Acid Catalysts for Selective Friedel-Crafts Reaction of Indoles and N-Sulfonylaldimines. Eur. J. Org. Chem. 2016, 2016, 502-507.

(3) Klosin, J.; Fontaine, P. P.; Figueroa, R. Development of Group IV Molecular Catalysts for High Temperature Ethylene-a-Olefin Copolymerization Reactions. Acc. Chem. Res. 2015, 48, 2004-2016.

(4) Beaumier, E. P.; Pearce, A. J.; See, X. Y.; Tonks, I. A. Modern applications of low-valent early transition metals in synthesis and catalysis. Nat. Rev. Chem. 2019, 3, 15-34.

(5) Okamoto, S. Synthetic Reactions Using Low-valent Titanium Reagents Derived from $\mathrm{Ti}(\mathrm{OR})_{4}$ or $\mathrm{CpTiX}_{3}\left(\mathrm{X}=\mathrm{O}-{ }^{\mathrm{i}}{ }^{-} \mathrm{Pr}\right.$ or $\left.\mathrm{Cl}\right)$ in the Presence of $\mathrm{Me} 3 \mathrm{SiCl}$ and $\mathrm{Mg}$. Chem. Rec. 2016, 16, 857-872.

(6) Chirik, P. J.; Bouwkamp, M. W. Complexes of Titanium in Oxidation States 0 to II. In Comprehensive Organometallic Chemistry III; Crabtree, R. H., Ed.; Elsevier: Oxford, 2007; Chapter 4.03, pp 243-279.

(7) Buchwald, S. L.; Nielsen, R. B. Group-4 Metal-Complexes of Benzynes, Cycloalkynes, Acyclic Alkynes, and Alkenes. Chem. Rev. 1988, 88, 1047-1058.

(8) Lenoir, D. The Application of Low-Valent Titanium Reagents in Organic-Synthesis. Synthesis 1989, 1989, 883-897.

(9) Furstner, A. Chemistry of and with Highly Reactive Metals. Angew. Chem., Int. Ed. Engl. 1993, 32, 164-189.

(10) Aleandri, L. E.; Bogdanovic, B.; Gaidies, A.; Jones, D. J.; Liao, S. J.; Michalowicz, A.; Roziere, J.; Schott, A. $\left[\mathrm{Ti}(\mathrm{MgCl})_{2}(\mathrm{THF})_{\mathrm{x}}\right]$ - a Reagent for the Mcmurry Reaction and a Novel Inorganic Grignard Complex. J. Organomet. Chem. 1993, 459, 87-93.

(11) Mori, M. Activation of nitrogen for organic synthesis. J. Organomet. Chem. 2004, 689, 4210-4227.

(12) Ozerov, O. V.; Patrick, B. O.; Ladipo, F. T. Highly Regioselective $[2+2+2]$ Cycloaddition of Terminal Alkynes Catalyzed by $\eta^{6}$-Arene Complexes of Titanium Supported by
Dimethylsilyl-Bridged p-tert-Butyl Calix[4]arene Ligand. J. Am. Chem. Soc. 2000, 122, 6423-6431.

(13) Rosenthal, U.; Pellny, P.-M.; Kirchbauer, F. G.; Burlakov, V. V. What Do Titano- and Zirconocenes Do with Diynes and Polyynes? Acc. Chem. Res. 2000, 33, 119-129.

(14) Suzuki, N.; Tsuchiya, T.; Aihara, N.; Iwasaki, M.; Saburi, M.; Chihara, T.; Masuyama, Y. Synthesis and Structure of SevenMembered Metallacycloalkynes. Eur. J. Inorg. Chem. 2013, 2013, 347-356.

(15) Cohen, S. A.; Auburn, P. R.; Bercaw, J. E. Structure and reactivity of bis(pentamethylcyclopentadienyl)(ethylene)titanium(II), a simple olefin adduct of titanium. J. Am. Chem. Soc. 1983, 105, $1136-1143$.

(16) Cohen, S. A.; Bercaw, J. E. Titanacycles derived from reductive coupling of nitriles, alkynes, acetaldehyde, and carbon dioxide with bis(pentamethylcyclopentadienyl)(ethylene)titanium(II). Organometallics 1985, 4, 1006-1014.

(17) Otten, E.; Batinas, A. A.; Meetsma, A.; Hessen, B. Versatile Coordination of Cyclopentadienyl-Arene Ligands and Its Role in Titanium-Catalyzed Ethylene Trimerization. J. Am. Chem. Soc. 2009, $131,5298-5312$.

(18) Sato, F.; Urabe, H.; Okamoto, S. Synthesis of Organotitanium Complexes from Alkenes and Alkynes and Their Synthetic Applications. Chem. Rev. 2000, 100, 2835-2886.

(19) You, Y. J.; Girolami, G. S. Mono(cyclopentadienyl)titanium(II) complexes with hydride, alkyl, and tetrahydroborate ligands: Synthesis, crystal structures, and ethylene dimerization and trimerization catalysis. Organometallics 2008, 27, 3172-3180.

(20) Fürstner, A.; Bogdanović, B. New Developments in the Chemistry of Low-Valent Titanium. Angew. Chem., Int. Ed. Engl. 1996, 35, 2442-2469.

(21) McMurry, J. E. Carbonyl-coupling reactions using low-valent titanium. Chem. Rev. 1989, 89, 1513-1524.

(22) Hashimoto, Y.; Mizuno, U.; Matsuoka, H.; Miyahara, T.; Takakura, M.; Yoshimoto, M.; Oshima, K.; Utimoto, K.; Matsubara, S. Structural Studies of the Low-Valent Titanium "Solution": What Goes on in the Pinacol Coupling Reaction? J. Am. Chem. Soc. 2001, $123,1503-1504$

(23) Lapointe, R. E.; Wolczanski, P. T.; Mitchell, J. F. CarbonMonoxide Cleavage by $(\mathrm{Silox})_{3} \mathrm{Ta}\left(\mathrm{Silox}={ }^{\mathrm{t}} \mathrm{Bu}_{3} \mathrm{SiO}\right)$. J. Am. Chem. Soc. 1986, 108, 6382-6384.

(24) Knobloch, D. J.; Lobkovsky, E.; Chirik, P. J. Dinitrogen cleavage and functionalization by carbon monoxide promoted by a hafnium complex. Nat. Chem. 2010, 2, 30.

(25) Crescenzi, R.; Solari, E.; Floriani, C.; Chiesi-Villa, A.; Rizzoli, C. Binding of a meso-Octaethyl Tris(pyrrole)-Mono(pyridine) Ligand to Titanium(III) and Titanium(IV): A Monomeric Titanium(IV) Oxo Bis(pyridine)-Bis(pyrrole) Complex Derived from the $\mathrm{C}-\mathrm{O}$ Bond Cleavage of Carbon Monoxide. Organometallics 1996, 15, $5456-5458$

(26) Steffey, B. D.; Chamberlain, L. R.; Chesnut, R. W.; Chebi, D. E.; Fanwick, P. E.; Rothwell, I. P. Intramolecular Activation of Aliphatic and Aromatic Carbon-Hydrogen Bonds by Tantalum(III) Metal Centers - Synthesis and Structure of the Bis-Metalated Compounds $\mathrm{Ta}\left(\mathrm{OC}_{6} \mathrm{H}_{3} \mathrm{Bu}^{\mathrm{t}} \mathrm{CMe}_{2} \mathrm{CH}_{2}\right)_{2} \mathrm{Cl}$ and $\mathrm{Ta}$ $\left(\mathrm{OC}_{6} \mathrm{H}_{3} \mathrm{PhC}_{6} \mathrm{H}_{4}\right)_{2}\left(\mathrm{OAr}-2,6-\mathrm{Ph}_{2}\right)\left(\mathrm{OAr}-2,6-\mathrm{Ph}_{2}=2,6\right.$-Diphenylphenoxide). Organometallics 1989, 8, 1419-1423.

(27) Yu, J. S.; Fanwick, P. E.; Rothwell, I. P. Intramolecular Alkane Dehydrogenation and Functionalization at Niobium Metal Centers. J. Am. Chem. Soc. 1990, 112, 8171-8172.

(28) Figueroa, J. S.; Piro, N. A.; Mindiola, D. J.; Fickes, M. G.; Cummins, C. C. Niobaziridine Hydrides. Organometallics 2010, 29, 5215-5229.

(29) Tayebani, M.; Feghali, K.; Gambarotta, S.; Yap, G. Molecular Rearrangements of a Low-Valent Niobium Amide: Ligand C-H Bond Oxidative Addition and Reductive Elimination. Organometallics 1998, $17,4282-4290$.

(30) Riley, P. N.; Clark, J. R.; Fanwick, P. E.; Rothwell, I. P. Synthesis and structure of niobium and tantalum derivatives of 
bis(dicyclohexylphosphino)methane (dcpm). Inorg. Chim. Acta 1999, $288,35-39$.

(31) Messerle, L. Metal-metal bonded dinuclear and organodimetallic complexes of the early transition metals (Groups 4 and 5): synthesis, structure, and reactivity. Chem. Rev. 1988, 88, 12291254.

(32) LaPointe, R. E.; Wolczanski, P. T.; Mitchell, J. F. Carbon monoxide cleavage by $(\text { silox })_{3} \mathrm{Ta}$ (silox $\left.=t-\mathrm{Bu}_{3} \mathrm{SiO}-\right)$. J. Am. Chem. Soc. 1986, 108, 6382-6384.

(33) Bercaw, J. E.; Bell, L. G.; Brintzinger, H.; Marvich, R. H. Titanocene as an Intermediate in Reactions Involving MolecularHydrogen and Nitrogen. J. Am. Chem. Soc. 1972, 94, 1219-1238.

(34) Brintzinger, H.; Bercaw, J. E. Nature of so-called titanocene, $\left(\mathrm{C}_{10} \mathrm{H}_{10} \mathrm{Ti}\right)_{2}$. J. Am. Chem. Soc. 1970, 92, 6182-6185.

(35) Fryzuk, M. D. Activation and functionalization of molecular nitrogen by metal complexes. Chem. Rec. 2003, 3, 2-11.

(36) Shima, T.; Hu, S. W.; Luo, G.; Kang, X. H.; Luo, Y.; Hou, Z. M. Dinitrogen Cleavage and Hydrogenation by a Trinuclear Titanium Polyhydride Complex. Science 2013, 340, 1549-1552.

(37) Tayebani, M.; Feghali, K.; Gambarotta, S.; Yap, G. Molecular rearrangements of a low-valent niobium amide: Ligand $\mathrm{C}-\mathrm{H}$ bond oxidative addition and reductive elimination. Organometallics 1998, 17, 4282-4290.

(38) Araya, M. A.; Cotton, F. A.; Matonic, J. H.; Murillo, C. A. An Efficient Reduction Process Leading to Titanium(II) and Niobium(II): Preparation and Structural Characterization of trans- $\mathrm{MCl}_{2}(\mathrm{py})_{4}$ Compounds, $\mathrm{M}=\mathrm{Ti}, \mathrm{Nb}$, and $\mathrm{Mn}$. Inorg. Chem. 1995, 34, 54245428.

(39) Edema, J. J. H.; Duchateau, R.; Gambarotta, S.; Hynes, R.; Gabe, E. Novel titanium(II) amine complexes $\mathrm{L}_{4} \mathrm{TiCl}_{2}[\mathrm{~L}=1 / 2$ $\mathrm{N}, \mathrm{N}, \mathrm{N}^{\prime}, \mathrm{N}^{\prime}$-tetramethylethylenediamine (TMEDA), $1 / 2 \mathrm{~N}, \mathrm{~N}, \mathrm{~N}^{\prime}-$ trimethylethylenediamine, pyridine, $1 / 2 \quad 2,2^{\prime}$-bipyridine]: synthesis and crystal structure of monomeric trans-(TMEDA) ${ }_{2} \mathrm{TiCl}_{2}$. Inorg. Chem. 1991, 30, 154-156.

(40) Wijeratne, G. B.; Zolnhofer, E. M.; Fortier, S.; Grant, L. N.; Carroll, P. J.; Chen, C.-H.; Meyer, K.; Krzystek, J.; Ozarowski, A.; Jackson, T. A.; Mindiola, D. J.; Telser, J. Electronic Structure and Reactivity of a Well-Defined Mononuclear Complex of Ti(II). Inorg. Chem. 2015, 54, 10380-10397.

(41) Snead, T. E. Dicarbonylbis(cyclopentadienyl)titanium. In Encyclopedia of Reagents for Organic Synthesis; John Wiley \& Sons, Ltd., 2001.

(42) Kool, L. B.; Rausch, M. D.; Alt, H. G.; Herberhold, M.; Thewalt, U.; Wolf, B. $\left[\mathrm{Cp}_{2} \mathrm{Ti}_{(}\left(\mathrm{PMe}_{3}\right)_{2}\right]-\mathrm{A}$ Versatile Source of Titanocene Derivatives. Angew. Chem., Int. Ed. Engl. 1985, 24, 394401.

(43) Spencer, M. D.; Wilson, S. R.; Girolami, G. S. Butadiene Complexes of Titanium(II) and Titanium(0): Synthesis, Butadiene Dimerization Catalysis, and Crystal Structures of $\mathrm{TiMe}_{2}\left(\eta^{4}-1,4-\right.$ $\left.\mathrm{C}_{4} \mathrm{H}_{4} \mathrm{Ph}_{2}\right)(\mathrm{dmpe})$ and $\mathrm{Ti}\left(\eta^{4}-\mathrm{C}_{4} \mathrm{H}_{6}\right)_{2}(\mathrm{dmpe})$. Organometallics 1997, $16,3055-3067$.

(44) Boynton, J. N.; Guo, J.-D.; Grandjean, F.; Fettinger, J. C.; Nagase, S.; Long, G. J.; Power, P. P. Synthesis and Characterization of the Titanium Bisamide Ti $\left\{\mathrm{N}(\mathrm{H}) \mathrm{Ar}^{\mathrm{iPr} 6}\right\} 2\left(\mathrm{Ar}^{\mathrm{iPr6}}=\mathrm{C}_{6} \mathrm{H}_{3}-2,6-\left(\mathrm{C}_{6} \mathrm{H}_{2}-\right.\right.$ 2,4,6- $\left.{ }^{\mathrm{i}} \mathrm{Pr}_{3}\right)_{2}$ and Its $\mathrm{TiCl}\left\{\mathrm{N}(\mathrm{H}) \mathrm{Ar}^{\mathrm{iPr} 6}\right\}_{2}$ Precursor: $\mathrm{Ti}(\mathrm{II}) \rightarrow \mathrm{Ti}(\mathrm{IV})$ Cyclization. Inorg. Chem. 2013, 52, 14216-14223.

(45) Hagadorn, J. R; Arnold, J. Tethered Bis-Amidinates as Supporting Ligands: A Concerted Elimination $/ \sigma-\pi$ Rearrangement Reaction Forming an Unusual Titanium Arene Complex. Angew. Chem., Int. Ed. 1998, 37, 1729-1731.

(46) Nakanishi, Y.; Ishida, Y.; Kawaguchi, H. Synthesis and reactions of a zirconium naphthalene complex bearing a tetraanionic C-capped triaryloxide ligand. Dalton Trans. 2016, 45, 15879-15885.

(47) Tsai, Y.-C.; Wang, P.-Y.; Lin, K.-M.; Chen, S.-A.; Chen, J.-M. Synthesis and reactions of $\beta$-diketiminato divanadium(i) invertedsandwich complexes. Chem. Commun. 2008, 205-207.

(48) Watanabe, T.; Ishida, Y.; Matsuo, T.; Kawaguchi, H. Syntheses and structures of zirconium(IV) complexes supported by 2,6-diadamantylaryloxide ligands and formation of arene-bridged dizirco- nium complexes with an inverse sandwich structure. Dalton Trans. 2010, 39, 484-491.

(49) Huang, W.; Dulong, F.; Wu, T.; Khan, S. I.; Miller, J. T.; Cantat, T.; Diaconescu, P. L. A six-carbon $10 \pi$-electron aromatic system supported by group 3 metals. Nat. Commun. 2013, 4, 1448.

(50) Graham, T. W.; Kickham, J.; Courtenay, S.; Wei, P.; Stephan, D. W. Reduction of Titanium(IV)-Phosphinimide Complexes: Routes to $\mathrm{Ti}(\mathrm{III})$ Dimers, $\mathrm{Ti}(\mathrm{IV})-$ Metallacycles, and $\mathrm{Ti}(\mathrm{II})$ Species. Organometallics 2004, 23, 3309-3318.

(51) Aguilar-Calderón, J. R.; Metta-Magaña, A. J.; Noll, B.; Fortier, S. $\mathrm{C}\left(\mathrm{sp}^{3}\right)-\mathrm{H}$ Oxidative Addition and Transfer Hydrogenation Chemistry of a Titanium(II) Synthon: Mimicry of Late-Metal Type Reactivity. Angew. Chem., Int. Ed. 2016, 55, 14101-14105.

(52) Spannenberg, A.; Tillack, A.; Arndt, P.; Kirmse, R.; Kempe, R. Homoleptic trisaminopyridinato M-III complexes $(\mathrm{M}=\mathrm{Ti}, \mathrm{V}$ and Cr), synthesis, structure and EPR investigations. Polyhedron 1998, 17, 845-850.

(53) Bailey, B. C.; Basuli, F.; Huffman, J. C.; Mindiola, D. J. Terminal titanium(IV) (trimethylsilyl)imides prepared by oxidatively induced trimethylsilyl abstraction. Organometallics 2006, 25, 27252728.

(54) Haas, I.; Hubner, C.; Kretschmer, W. P.; Kempe, R. A Highly Efficient Titanium Catalyst for the Synthesis of Ultrahigh-MolecularWeight Polyethylene (UHMWPE). Chem. - Eur. J. 2013, 19, 91329136.

(55) Shannon, R. D. Revised Effective Ionic-Radii and Systematic Studies of Interatomic Distances in Halides and Chalcogenides. Acta Crystallogr., Sect. A: Cryst. Phys., Diffr., Theor. Gen. Crystallogr. 1976, 32, 751-767.

(56) Mullins, S. M.; Duncan, A. P.; Bergman, R. G.; Arnold, J. Reactivity of a Titanium Dinitrogen Complex Supported by Guanidinate Ligands: Investigation of Solution Behavior and a Novel Rearrangement of Guanidinate Ligands. Inorg. Chem. 2001, 40, 6952-6963.

(57) Hagadorn, J. R.; Arnold, J. Low-valent chemistry of titanium benzamidinates leading to new $\mathrm{Ti} \mu-\mathrm{N}_{2}, \mu$-O, alkyl derivatives, and the cyclometalation of TMEDA. J. Am. Chem. Soc. 1996, 118, 893-894.

(58) Loh, Y. K.; Ángeles Fuentes, M.; Vasko, P.; Aldridge, S. Successive Protonation of an N-Heterocyclic Imine Derived Carbonyl: Superelectrophilic Dication Versus Masked Acylium Ion. Angew. Chem., Int. Ed. 2018, 57, 16559-16563.

(59) Wu, X.; Tamm, M. Transition metal complexes supported by highly basic imidazolin-2-iminato and imidazolin-2-imine $\mathrm{N}$-donor ligands. Coord. Chem. Rev. 2014, 260, 116.

(60) Connelly, N. G.; Geiger, W. E. Chemical Redox Agents for Organometallic Chemistry. Chem. Rev. 1996, 96, 877-910.

(61) Basuli, F.; Kilgore, U. J.; Brown, D.; Huffman, J. C.; Mindiola, D. J. Terminal Zirconium Imides Prepared by Reductive $\mathrm{C}-\mathrm{N}$ Bond Cleavage. Organometallics 2004, 23, 6166-6175.

(62) Basuli, F.; Huffman, J. C.; Mindiola, D. J. Reductive C-N bond cleavage of the NCCCN $\beta$-diketiminate backbone: A direct approach to azabutadienyl and alkylidene-anilide scaffolds. Inorg. Chim. Acta 2007, 360, 246-254.

(63) Cotton, F. A.; Daniels, L. M.; Murillo, C. A.; Wang, X. P. Cleavage of formamidinate ligands on a $\mathrm{Ta}=\mathrm{Ta}$ double bond: Formation of HxC-NAryl ( $\mathrm{x}=0$ and 1) and arylimido-bridged complexes. Inorg. Chem. 1997, 36, 896-901.

(64) Hagadorn, J. R.; Arnold, J. Titanium(II), -(III), and -(IV) Complexes Supported by Benzamidinate Ligands. Organometallics 1998, 17, 1355-1368.

(65) Bailey, B. C.; Basuli, F.; Huffman, J. C.; Mindiola, D. J. Oxidatively induced alpha-hydrogen abstraction. A mild protocol to generate terminal titanium alkylidenes containing a beta-hydrogen. Organometallics 2006, 25, 3963-3968.

(66) Ferreira, M. J.; Matos, I.; Ascenso, J. R.; Duarte, M. T.; Marques, M. M.; Wilson, C.; Martins, A. M. Alkylation, cation formation, and insertion reactions in titanium tris(ketimide) complexes. Organometallics 2007, 26, 119-127. 
(67) Jensen, B. S.; Parker, V. D. Reversible anion radical-dianion redox equilibria involving ions of simple aromatic compounds. $J$. Chem. Soc., Chem. Commun. 1974, 0, 367-368.

(68) Bouwkamp, M. W.; Budzelaar, P. H. M.; Meetsma, A.; Hessen, B. Reactivity of cationic decamethylmetallocene complexes towards ketones. J. Organomet. Chem. 2011, 696, 1920-1924.

(69) Cole, S. C.; Coles, M. P.; Hitchcock, P. B. Transition-metal imido-boroxide complexes: a structural and spectroscopic investigation of the influence of boron. J. Chem. Soc., Dalton Trans. 2002, $4168-4174$

(70) Fleischer, E. B.; Sung, N.; Hawkinson, S. Crystal structure of benzophenone. J. Phys. Chem. 1968, 72, 4311-4312.

(71) Lam, C. P.; Anthon, C.; Heinemann, F. W.; O'Connor, J. M.; Meyer, K. Structural and spectroscopic characterization of a chargeseparated uranium benzophenone ketyl radical complex. J. Am. Chem. Soc. 2008, 130, 6567-6576.

(72) Matson, E. M.; Kiernicki, J. J.; Anderson, N. H.; Fanwick, P. E.; Bart, S. C. Isolation of a uranium(III) benzophenone ketyl radical that displays redox-active ligand behaviour. Dalton Trans. 2014, 43, $17885-17888$.

(73) Hou, Z.; Jia, X.; Fujita, A.; Tezuka, H.; Yamazaki, H.; Wakatsuki, Y. Alkali and Alkaline-Earth Metal Ketyl Complexes: Isolation, Structural Diversity, and Hydrogenation/Protonation Reactions. Chem. - Eur. J. 2000, 6, 2994-3005.

(74) Covert, K. J.; Wolczanski, P. T.; Hill, S. A.; Krusic, P. J. Ketyl Complexes of $(\text { silox })_{3} \mathrm{Ti}\left(\right.$ silox $={ }^{\mathrm{t}} \mathrm{Bu}_{3} \mathrm{SiO}$-). Inorg. Chem. 1992, 31, $66-78$.

(75) Lewis, R. A.; MacLeod, K. C.; Mercado, B. Q.; Holland, P. L. Geometric and redox flexibility of pyridine as a redox-active ligand that can reversibly accept one or two electrons. Chem. Commun. 2014, 50, 11114-11117.

(76) Durfee, L. D.; Fanwick, P. E.; Rothwell, I. P.; Folting, K.; Huffman, J. C. Reductive elimination pathways to low valent titanium aryl oxide complexes. J. Am. Chem. Soc. 1987, 109, 4720-4722.

(77) Kisko, J. L.; Hascall, T.; Parkin, G. Multiple bonding of titanium and vanadium to the heavier chalcogens: Syntheses and structures of the terminal selenido and tellurido complexes $\left[\eta^{4}\right.$ $\mathrm{Me}_{8}$ taa $] \mathrm{M}=\mathrm{E}(\mathrm{M}=\mathrm{Ti}, \mathrm{V} ; \mathrm{E}=\mathrm{Se}, \mathrm{Te}) . \mathrm{J}$. Am. Chem. Soc. 1997, 119, $7609-7610$.

(78) Allen, J. M.; Ellis, J. E. Synthesis and characterization of titanium tetraisocyanide complexes, $\left[\mathrm{CpTi}(\mathrm{CNXyl})_{4} \mathrm{E}\right], \mathrm{E}=\mathrm{I}, \mathrm{SnPh}_{3}$, and $\mathrm{SnMe}_{3}$. J. Organomet. Chem. 2008, 693, 1536-1542.

(79) Kool, L. B.; Rausch, M. D.; Herberhold, M.; Alt, H. G.; Thewalt, U.; Honold, B. Diamagnetic Isocyanide Complexes of Titanium, Zirconium, and Hafnium. Organometallics 1986, 5, 24652468.

(80) Reiss, F.; Altenburger, K.; Hollmann, D.; Spannenberg, A.; Jiao, H. J.; Arndt, P.; Rosenthal, U.; Beweries, T. Redox-Disproportionation of a Decamethyltitanocene(III) Isonitrile Alkynyl Complex. Chem. - Eur. J. 2017, 23, 7891-7895.

(81) Cuenca, T.; Gomez, R.; Gomezsal, P.; Royo, P. Synthesis and Characterization of Ansa-Dimethylsilylbiscyclopentadienyl Titanium(II) Complexes - Crystal-Structure of $\left[\mathrm{Ti}\left(\mathrm{Me}_{2} \mathrm{Si}\left(\mathrm{C}_{5} \mathrm{H}_{4}\right)_{2}\right)(\mathrm{CN}(2,6-\right.$ $\left.\left.\mathrm{Me}_{2} \mathrm{C}_{6} \mathrm{H}_{3}\right)\right)_{2}$ ]. J. Organomet. Chem. 1993, 454, 105-111.

(82) Greidanus-Strom, G.; Carter, C. A. G.; Stryker, J. M. Migratory insertion of isonitriles into titanacyclobutane complexes. A novel stereocontrolled synthesis of substituted cyclobutanimines. Organometallics 2002, 21, 1011-1013.

(83) Entley, W. R.; Treadway, C. R.; Wilson, S. R.; Girolami, G. S. The hexacyanotitanate ion: Synthesis and crystal structure of $\left[\mathrm{NEt}_{4}\right]_{3}\left[\mathrm{Ti}-\mathrm{III}(\mathrm{CN})_{6}\right]$ center $4 \mathrm{MeCN}$. J. Am. Chem. Soc. 1997, 119, 6251-6258.

(84) Brown, A.; Saber, M.; Van den Heuvel, W.; Schulte, K.; Soncini, A.; Dunbar, K. R. Titanium(III) Member of the Family of Trigonal Building Blocks with Scorpionate and Cyanide Ligands. Inorg. Chem. 2017, 56, 1031-1035.

(85) Thewalt, U.; Nuding, W. Titanium(IV) compounds with cyano ligands: Crystal structures of $\mathrm{Cp}_{2} \mathrm{Ti}(\mathrm{CN})\left(\mathrm{OCH}_{3}\right)$ and $\left[\mathrm{Cp}_{2}(\mathrm{Ti}-\right.$ $(\mathrm{CN})]_{2}$ O. J. Organomet. Chem. 1996, 512, 127-130.
(86) Carbo, J. J.; Garcia-Lopez, D.; Gonzalez-del Moral, O.; Martin, A.; Mena, M.; Santamaria, C. Carbon-Nitrogen Bond Construction and Carbon-Oxygen Double Bond Cleavage on a Molecular Titanium Oxonitride: A Combined Experimental and Computational Study. Inorg. Chem. 2015, 54, 9401-9412.

(87) Klouras, N.; Nastopoulos, V.; Tzavellas, N.; Leban, I. Cyano Derivatives of Bis(Cyclopentadienyl)Titanium(IV) - the Crystal and Molecular Structure of $\mu$-Oxo-Bis[Bis(Cyclopentadienyl)Cyanotitanium(IV) $],\left[\left(\eta^{5}-\mathrm{C}_{5} \mathrm{H}_{5}\right)_{2} \mathrm{TiCN}\right]_{2} \mathrm{O}$. Z. Anorg. Allg. Chem. 1995, 621, 1767-1770.

(88) Gambarotta, S.; Floriani, C.; Chiesi-Villa, A.; Guastini, C. Decamethylvanadocene chemistry: synthesis, structure, and reactions of vanadium(II) and vanadium(III) derivatives with carbon monoxide and isocyanides. Inorg. Chem. 1984, 23, 1739-1747.

(89) Martins, A. M.; Marques, M. M.; Ascenso, J. R.; Dias, A. R.; Duarte, M. T.; Fernandes, A. C.; Fernandes, S.; Ferreira, M. J.; Matos, I.; Conceicao Oliveira, M.; Rodrigues, S. S.; Wilson, C. Titanium and zirconium ketimide complexes: synthesis and ethylene polymerisation catalysis. J. Organomet. Chem. 2005, 690, 874-884.

(90) Basuli, F.; Watson, L. A.; Huffman, J. C.; Mindiola, D. J. Phosphaazaallene and phosphinylimide complexes stemming from a terminal and four-coordinate titanium phosphinidene. Dalton Trans. 2003, 4228-4229.

(91) Mullane, K. C.; Cheisson, T.; Nakamaru-Ogiso, E.; Manor, B. C.; Carroll, P. J.; Schelter, E. J. Reduction of Carbonyl Groups by Uranium(III) and Formation of a Stable Amide Radical Anion. Chem. - Eur. J. 2018, 24, 826-837.

(92) Gianetti, T. L.; Bergman, R. G.; Arnold, J. Carbon-fluorine bond cleavage in fluoroarenes via a niobium(III) imido complex: from stoichiometric to catalytic hydrodefluorination. Chem. Sci. 2014, 5, 2517-2524.

(93) Smith, M. R.; Matsunaga, P. T.; Andersen, R. A. Preparation of Monomeric $\left(\mathrm{Me}_{5} \mathrm{C}_{5}\right)_{2} \mathrm{VO}$ and $\left(\mathrm{Me}_{5} \mathrm{C}_{5}\right)_{2} \mathrm{Ti}(\mathrm{O})(\mathrm{L})$ and Their Decomposition to $\left(\mathrm{Me}_{5} \mathrm{C}_{5}\right) \mathrm{M}_{4}(\mu-\mathrm{O})_{6}$. J. Am. Chem. Soc. 1993, 115, 7049-7050.

(94) Sweeney, Z. K.; Polse, J. L.; Bergman, R. G.; Andersen, R. A. Dihydrogen Activation by Titanium Sulfide Complexes. Organometallics 1999, 18, 5502-5510.

(95) Howard, W. A.; Parkin, G. Interconversion of Hydrosulfido and Sulfido Ligands in Permethylzirconocene Complexes. Organometallics 1993, 12, 2363-2366.

(96) Howard, W. A.; Parkin, G. Terminal oxo, sulfido, selenido, and tellurido complexes of zirconium, $\left(\eta^{5}-\mathrm{C}_{5} \mathrm{Me}_{4} \mathrm{R}\right)_{2} \mathrm{Zr}(\mathrm{E})\left(\mathrm{NC}_{5} \mathrm{H}_{5}\right)$ : comparison of terminal $\mathrm{Zr}-\mathrm{E}$ single and $\mathrm{Zr}$ : $\mathrm{E}$ double-bond lengths. J. Am. Chem. Soc. 1994, 116, 606-615.

(97) Kayal, A.; Kuncheria, J.; Lee, S. C. Bis[hydrotris(pyrazol-1yl)borato]titanium(II): a stable $\mathrm{Tp}_{2} \mathrm{M}$ complex of singular reactivity. Chem. Commun. 2001, 2482-2483.

(98) Mendiratta, A.; Figueroa, J. S.; Cummins, C. C. Synthesis of a four-coordinate titanium(iv) oxoanion via deprotonation and decarbonylation of complexed formate. Chem. Commun. 2005, 3403-3405.

(99) Hazari, N.; Mountford, P. Reactions and Applications of Titanium Imido Complexes. Acc. Chem. Res. 2005, 38, 839-849.

(100) Hagadorn, J. R.; Arnold, J. Preparation of complexes containing $\mathrm{Ti}=\mathrm{E}, \mathrm{Ti}_{2}\left(\mu-\mathrm{E}_{2}\right)$ and $\mathrm{Ti}\left(\eta^{2}-\mathrm{E}_{2}\right)(\mathrm{E}=\mathrm{O}, \mathrm{S})$ functionalities from a reactive titanium dinitrogen complex. Inorg. Chem. 1997, 36, $2928-2929$.

(101) Hanna, T. E.; Keresztes, I.; Lobkovsky, E.; Bernskoetter, W. H.; Chirik, P. J. Synthesis of a Base-Free Titanium Imido and a Transient Alkylidene from a Titanocene Dinitrogen Complex. Studies on TiNR Hydrogenation, Nitrene Group Transfer, and Comparison of 1,2-Addition Rates. Organometallics 2004, 23, 3448-3458.

(102) Hanna, T. E.; Lobkovsky, E.; Chirik, P. J. Dihydrogen and Silane Addition to Base-Free, Monomeric Bis(cyclopentadienyl) titanium Oxides. Inorg. Chem. 2007, 46, 2359-2361.

(103) Duchateau, R.; Williams, A. J.; Gambarotta, S.; Chiang, M. Y. Carbon-carbon double-bond formation in the intermolecular acetonitrile reductive coupling promoted by a mononuclear titanium- 
(II) compound. Preparation and characterization of two titanium(IV) imido derivatives. Inorg. Chem. 1991, 30, 4863-4866.

(104) Muller, U.; Krug, V. $\left[\mathrm{TiSCl}_{4}\right]^{2-}$ and $\left[\mathrm{Ti}_{3} \mathrm{O}\left(\mathrm{S}_{2}\right)_{3} \mathrm{Cl}_{6}\right]^{2-}$, a Multinuclear Complex with a Structure Typical for Clusters. Angew. Chem., Int. Ed. Engl. 1988, 27, 293-294.

(105) Hsu, S. H.; Chang, J. C.; Lai, C. L.; Hu, C. H.; Lee, H. M.; Lee, G. H.; Peng, S. M.; Huang, J. H. Terminal titanium-ligand multiple bonds. Cleavages of $\mathrm{C}=\mathrm{O}$ and $\mathrm{C}=\mathrm{S}$ double bonds with $\mathrm{Ti}$ imido complexes. Inorg. Chem. 2004, 43, 6786-6792.

(106) Lundmark, P. J.; Kubas, G. J.; Scott, B. L. Formation of an anionic titanium(IV) sulfide dimer, $\left\{\mathrm{Na}_{2}[\mathrm{CpTi}(\mu-\mathrm{S})(\mathrm{S})]_{2} \cdot 4 \mathrm{THF}\right\}_{2}$, by elimination of $\mathrm{CpH}$ and $\mathrm{H}_{2}$ from $\mathrm{Cp}_{2} \mathrm{Ti}(\mathrm{SH})_{2}$ upon deprotonation with $\mathrm{NaH}$. Organometallics 1996, 15, 3631-3633.

(107) Komuro, T.; Matsuo, T.; Kawaguchi, H.; Tatsumi, K. Palladium dimethylsilanedithiolato complex: a precursor for Ti-Pd and $\mathrm{Ti}-\mathrm{Pd}_{2}$ heterometallic complexes. Chem. Commun. 2002, 988989.

(108) Sweeney, Z. K.; Polse, J. L.; Andersen, R. A.; Bergman, R. G.; Kubinec, M. G. Synthesis, structure, and reactivity of monomeric titanocene sulfido and disulfido complexes. Reaction of $\mathrm{H}_{2}$ with a terminal $\mathrm{M}=\mathrm{S}$ bond. J. Am. Chem. Soc. 1997, 119, 4543-4544.

(109) Ratti, C.; Richard, P.; Tabard, A.; Guilard, R. Synthesis and characterization of a new series of titanium(IV) porphyrins coordinated to a disulphur or a diselenium ligand. J. Chem. Soc., Chem. Commun. 1989, 69-70.

(110) Darwish, W.; Schlecht, S.; Schaper, A.; Froba, M.; Harms, K.; Massa, W.; Sundermeyer, J. Synthesis and Crystal Structures of Axially Substituted Titaniumphthalocyanines and Preparation of PcTi@SBA15 and PcTi\&TiOx@SBA-15 Materials. Z. Anorg. Allg. Chem. 2009, $635,1215-1224$.

(111) Verma, A. K.; Chou, J. H.; Rauchfuss, T. B. A polymeric binary titanium(IV) sulfide and its conversion to molecular Lewis base adducts. Inorg. Chem. 1998, 37, 5960-5963.

(112) Mullins, S. M.; Duncan, A. P.; Bergman, R. G.; Arnold, J. Reactivity of a Titanium Dinitrogen Complex Supported by Guanidinate Ligands: Investigation of Solution Behavior and a Novel Rearrangement of Guanidinate Ligands. Inorg. Chem. 2001, 40, 6952-6963.

(113) See, X. Y.; Beaumier, E. P.; Davis-Gilbert, Z. W.; Dunn, P. L.; Larsen, J. A.; Pearce, A. J.; Wheeler, T. A.; Tonks, I. A. Generation of Ti-II Alkyne Trimerization Catalysts in the Absence of Strong Metal Reductants. Organometallics 2017, 36, 1383-1390.

(114) SMART, version 2.1; Bruker AXS Inc.: Madison, WI, 2005.

(115) SAINT, version 7.34a; Bruker AXS Inc.: Madison, WI, 2005.

(116) Blessing, R. An empirical correction for absorption anisotropy. Acta Crystallogr., Sect. A: Found. Crystallogr. 1995, 51, 33-38.

(117) Sheldrick, G. M. SHELXTL, 6.12; Bruker AXS, Inc.: Madison, WI.

(118) Dolomanov, O. V.; Bourhis, L. J.; Gildea, R. J.; Howard, J. A. K.; Puschmann, H. OLEX2: a complete structure solution, refinement and analysis program. J. Appl. Crystallogr. 2009, 42, 339-341. 